\title{
GREAT PLAINS WIND ENERGY TRANSMISSION DEVELOPMENT PROJECT
}

\section{Final Technical Report}

(for the period of June 1, 2005, through December 31, 2011)

Prepared for:

AAD Document Control

National Energy Technology Laboratory

U.S. Department of Energy

626 Cochrans Mill Road

PO Box 10940, MS 921-107

Pittsburgh, PA 15236-0940

Agreement No. DE-FG36-05GO85037

Technical Monitor: Gary Nowakowski

Prepared by:

Brad G. Stevens, P.E.

Troy K. Simonsen Kerryanne M. Leroux

University of North Dakota Energy \& Environmental Research Center 15 North 23rd Street, Stop 9018

Grand Forks, ND 58202-9018 


\section{DISCLAIMERS}

This report was prepared as an account of work sponsored by an agency of the United States Government. Neither the United States Government, nor any agency thereof, nor any of their employees makes any warranty, express or implied, or assumes any legal liability or responsibility for the accuracy, completeness, or usefulness of any information, apparatus, product, or process disclosed or represents that its use would not infringe privately owned rights. Reference herein to any specific commercial product, process, or service by trade name, trademark, manufacturer, or otherwise does not necessarily constitute or imply its endorsement, recommendation, or favoring by the United States Government or any agency thereof. The views and opinions of authors expressed herein do not necessarily state or reflect those of the United States Government or any agency thereof.

\section{ACKNOWLEDGMENTS}

This report was prepared with the support of the U.S. Department of Energy (DOE) National Energy Technology Laboratory Cooperative Agreement No. DE-FG36-05GO85037. However, any opinions, findings, conclusions, or recommendations expressed herein are those of the authors(s) and do not necessarily reflect the views of DOE.

\section{NDIC DISCLAIMER}

This report was prepared by the Energy \& Environmental Research Center (EERC) pursuant to an agreement partially funded by the Industrial Commission of North Dakota, and neither the EERC nor any of its subcontractors nor the North Dakota Industrial Commission nor any person acting on behalf of either:

(A) Makes any warranty or representation, express or implied, with respect to the accuracy, completeness, or usefulness of the information contained in this report or that the use of any information, apparatus, method, or process disclosed in this report may not infringe privately owned rights; or

(B) Assumes any liabilities with respect to the use of, or for damages resulting from the use of, any information, apparatus, method, or process disclosed in this report.

Reference herein to any specific commercial product, process, or service by trade name, trademark, manufacturer, or otherwise does not necessarily constitute or imply its endorsement, recommendation, or favoring by the North Dakota Industrial Commission. The views and opinions of authors expressed herein do not necessarily state or reflect those of the North Dakota Industrial Commission

\section{EERC DISCLAIMER}

LEGAL NOTICE This research report was prepared by the Energy \& Environmental Research Center (EERC), an agency of the University of North Dakota, as an account of work sponsored by DOE. Because of the research nature of the work performed, neither the EERC nor any of its employees makes any warranty, express or implied, or assumes any legal liability or responsibility for the accuracy, completeness, or usefulness of any information, apparatus, product, or process disclosed or represents that its use would not infringe privately owned rights. Reference herein to any specific commercial product, process, or service by trade name, trademark, manufacturer, or otherwise does not necessarily constitute or imply its endorsement or recommendation by the EERC. 


\section{TABLE OF CONTENTS}

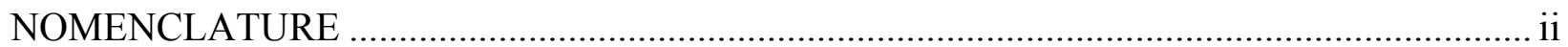

EXECUTIVE SUMMARY ............................................................................................ ii

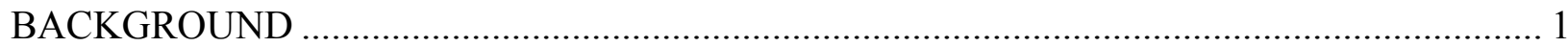

TASK 1 - REGIONAL RENEWABLE CREDIT TRACKING SYSTEM .............................. 2

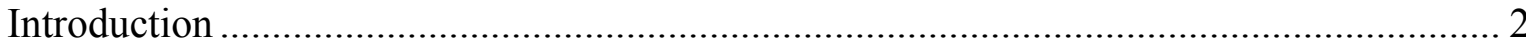

TASK 1 (RESCOPED) - SMALL WIND TURBINE TRAINING CENTER .......................... 2

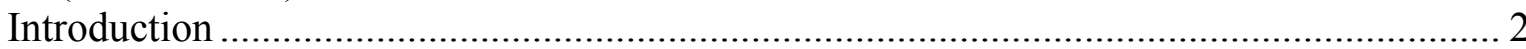

Task 1 - Scope of Activities ................................................................................... 3

Subtask 1 - Site Selection and Development ................................................... 3

Subtask 2 - Equipment Procurement and Installation ........................................... 3

Subtask 3 - Education and Outreach ............................................................. 4

TASK 2 - MULTISTATE TRANSMISSION COLLABORATIVE....................................... 4

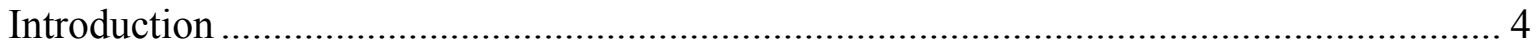

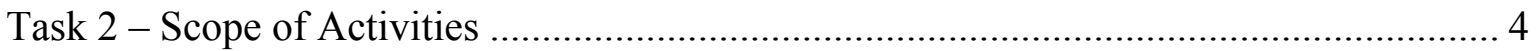

TASK 3 - WIND ENERGY FORECAST SYSTEM ........................................................ 5

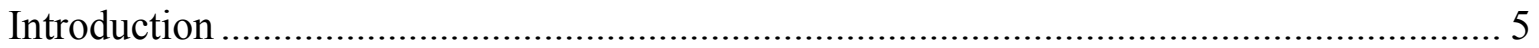

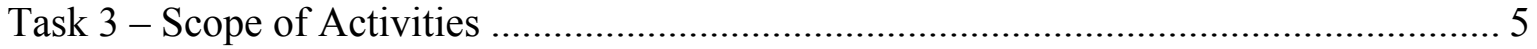

TASK 4 - ANALYSIS OF THE LONG-TERM ROLE OF HYDROGEN IN THE REGION.... 6

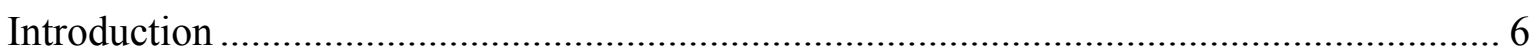

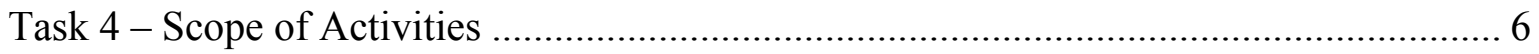

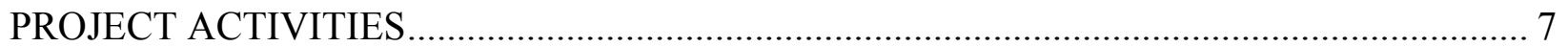

Task 1 - Small Wind Turbine Training Center................................................................. 7

Task 2 - Multistate Transmission Collaborative................................................................. 7

Task 3 - Wind Energy Forecasting Systems.............................................................. 8

Task 4 - Analysis of the Long-Term Role of Hydrogen in the Region ............................ 9

TASK 1 - SMALL WIND TURBINE TRAINING CENTER FINAL REPORT ........Appendix A

TASK 3 - WIND ENERGY-FORECASTING SYSTEM (WEFS)

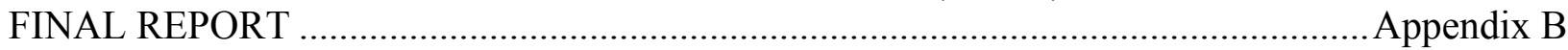

TASK 4 - ANALYSIS OF THE LONG-TERM ROLE OF HYDROGEN IN THE REGION TOPICAL REPORT .

Appendix C 


\section{NOMENCLATURE}

$\begin{array}{ll}\text { AWEA } & \text { American Wind Energy Association } \\ \text { DOE } & \text { U.S. Department of Energy } \\ \text { EERC } & \text { Energy \& Environmental Research Center } \\ \text { GUI } & \text { graphical user interface } \\ \text { MAE } & \text { mean absolute error } \\ \text { MISO } & \text { Midwest Independent System Operator } \\ \text { M-RETS } & \text { Midwest Renewable Energy Tracking System } \\ \text { NWCC } & \text { National Wind Coordinating Committee } \\ \text { REC } & \text { renewable energy certificates } \\ \text { RFP } & \text { request for proposal } \\ \text { SWTTC } & \text { Small Wind Turbine Training Center } \\ \text { UGPTC } & \text { Upper Great Plains Transmission Coalition } \\ \text { WEFS } & \text { wind energy forecast system } \\ \text { WOW } & \text { Wind of the Wires }\end{array}$




\section{GREAT PLAINS WIND ENERGY TRANSMISSION DEVELOPMENT PROJECT}

\section{EXECUTIVE SUMMARY}

In fiscal year 2005, the Energy \& Environmental Research Center (EERC) received funding from the U.S. Department of Energy (DOE) to undertake a broad array of tasks to either directly or indirectly address the barriers that faced much of the Great Plains states and their efforts to produce and transmit wind energy at the time. This program, entitled Great Plains Wind Energy Transmission Development Project, was focused on the central goal of stimulating wind energy development through expansion of new transmission capacity or development of new wind energy capacity through alternative market development.

The original task structure was as follows:

- Task 1: Regional Renewable Credit Tracking System (later rescoped to Small Wind Turbine Training Center)

- Task 2: Multistate Transmission Collaborative

- Task 3: Wind Energy Forecasting System

- Task 4: Analysis of the Long-Term Role of Hydrogen in the Region

As carried out, Task 1 involved the creation of the Small Wind Turbine Training Center (SWTTC). The SWTTC, located Grand Forks, North Dakota, consists of a single wind turbine, the Endurance S-250, on a 105-foot tilt-up guyed tower. The S-250 is connected to the electrical grid on the "load side" of the electric meter, and the power produced by the wind turbine is consumed locally on the property. Establishment of the SWTTC will allow EERC personnel to provide educational opportunities to a wide range of participants, including grade schoolthrough college-level students and the general public. In addition, the facility will allow the EERC to provide technical training workshops related to the installation, operation, and maintenance of small wind turbines.

In addition, under Task 1, the EERC hosted two small wind turbine workshops on May 18, 2010, and March 8, 2011, at the EERC in Grand Forks, North Dakota.

Task 2 involved the EERC cosponsoring and aiding in the planning of three transmission workshops in the midwest and western regions.

Under Task 3, the EERC, in collaboration with Meridian Environmental Services, developed and demonstrated the efficacy of a wind energy forecasting system for use in scheduling energy output from wind farms for a regional electrical generation and transmission utility. 
With the increased interest at the time of project award in the production of hydrogen as a critical future energy source, many viewed hydrogen produced from wind-generated electricity as an attractive option. In addition, many of the hydrogen production-related concepts involve utilization of energy resources without the need for additional electrical transmission.

For this reason, under Task 4, the EERC provided a summary of end uses for hydrogen in the region and focused on one end product in particular (fertilizer), including several process options and related economic analyses. 


\section{GREAT PLAINS WIND ENERGY TRANSMISSION DEVELOPMENT PROJECT}

\section{BACKGROUND}

In fiscal year 2005, the Energy \& Environmental Research Center (EERC) received funding from the U.S. Department of Energy (DOE) to undertake a broad array of tasks to either directly or indirectly address the barriers that faced much of the Great Plains states and their efforts to produce and transmit wind energy at the time. This program, entitled Great Plains Wind Energy Transmission Development Project, was focused on the central goal of stimulating wind energy development through expansion of new transmission capacity or development of new wind energy capacity through alternative market development. The project was initiated with the following objectives:

- Enhance the marketing opportunities for renewable energy through the development and implementation of a tracking system for renewable energy certificates (RECs) in the region.

- Organize and help facilitate a multistate collaborative related to transmission capacity development.

- Develop a wind energy forecast system, and demonstrate its efficacy in scheduling power output from wind farms in the Great Plains.

- Determine a road map for the long-term exporting of wind-derived products, such as hydrogen and fertilizer, in the Great Plains.

With these objectives in mind, the following task structure was created:

- Task 1 - Regional Renewable Credit Tracking System

- Task 2 - Multistate Transmission Collaborative

- Task 3 - Wind Energy Forecasting System

- Task 4 - Analysis of the Long-Term Role of Hydrogen in the Region

The tasks were identified based on discussions with many well-informed individuals and groups whose business is related to wind energy and transmission. Initially, some uncertainty existed whether all of the identified tasks would be performed. For instance, performance of Task 1 was contingent on acceptance of the EERC's proposal by the stakeholder group designing the regional renewable credit tracking system. If any of the proposed tasks were not undertaken, a revised project scope was submitted to DOE for approval. After some work had been performed on Task 1, Task 1 became "Task 1 - Small Wind Turbine Training Center." Since some work had been performed under the original Task 1 scope, it is included in this final report. 


\section{TASK 1 - REGIONAL RENEWABLE CREDIT TRACKING SYSTEM (LATER RESCOPED TO BE SMALL WIND TURBINE TRAINING CENTER)}

\section{Introduction}

Stakeholders in the upper Midwest states (Iowa, Wisconsin, Minnesota, North Dakota, and South Dakota) and Manitoba had been working with Powering the Plains and the Izaak Walton League to develop the design and operations of a Midwest Renewable Energy Tracking System (known as M-RETS). M-RETS would track RECs as products to be sold separate from the electricity. M-RETS was to be designed and implemented as a regional tracking system to support mandatory and voluntary renewable programs in the region. Participation in the tracking system was to be voluntary; however, the goal of M-RETS stakeholders was to design a system that would have sufficient appeal such that a majority of renewable generators and other market participants in the region would choose to participate.

To that end, the EERC proposed to develop M-RETS under this contract. It was the EERC's intent to offer the development of M-RETS product (with direction from M-RETS stakeholders) at a greatly reduced cost to M-RETS participants. In addition, the EERC intended to contract a technical advisor as part of this task. It was also the EERC's intent to request some level of cost share from M-RETS stakeholders as part of this task. The requested cost share was likely to be approximately $\$ 10,000$ to $\$ 20,000$.

It was the EERC's understanding that M-RETS stakeholders had planned to put out a request for proposals (RFP) to develop M-RETS. Unfortunately, M-RETS stakeholders chose to contract directly with a developer, and an RFP was never released.

To replace the activities originally proposed in Task 1, the EERC, in consultation with DOE, agreed to rescope Task 1 with a small wind energy focus. The revised Task 1 activities are summarized below.

\section{TASK 1 (RESCOPED) - SMALL WIND TURBINE TRAINING CENTER}

\section{Introduction}

Based on conversations with personnel from DOE and the continued need to educate the public about wind energy, EERC modified the original Task 1 scope of activities in DOE Award No. DE-FG36-05GO85037 to establish a small wind turbine technology training center.

The establishment of a small wind turbine technology training center would allow EERC personnel to provide educational opportunities to a wide range of participants, including grade school- through college-level students and the general public. In addition, the facility would allow the EERC to provide technical training workshops related to the installation, operation, and maintenance of small wind turbines. 
As detailed below, the proposed Task 1 activities involved the selection, development, and utilization of a site for education and outreach activities related to dissemination of general wind energy information and small wind turbine technology. Conceptually, the EERC would install up to three small wind turbines ranging in size from 1.8 to $20 \mathrm{~kW}$ at the site (budget permitting). The EERC would also host up to two technical workshops and as many educational events as the budget allowed at the site.

\section{Task 1 - Scope of Activities}

Upon acceptance of the revised statement of project objective by DOE, the following activities were performed under this task:

\section{Subtask 1 - Site Selection and Development}

- Identify and prioritize potential sites for development of the small wind turbine technology training center.

- Select a site based on land ownership, site access, electrical interconnection access, proximity to Grand Forks, availability of wind resource (i.e., openness, absence of obstructions), and other characteristics.

- Submit necessary permits and secure site development approval from appropriate governing bodies.

\section{Subtask 2 - Equipment Procurement and Installation}

- Identify up to three small wind turbines to be installed at the small wind turbine technology training center.

- Identify and procure necessary electrical infrastructure to interconnect the wind turbines.

- Negotiate with vendors for the purchase and delivery of small wind turbines.

- Negotiate with local contractors for the installation of electrical infrastructure.

- Install wind turbines and associated electrical devices at the site.

- In addition to the installation of wind turbines, it is the EERC's intent to install a windmonitoring system that is currently in the EERC's possession.

- If the EERC can secure a funding source, an educational kiosk will be installed to provide a staging area for presentations and facilitated and self-directed tours. 


\section{Subtask 3 - Education and Outreach}

- Host up to two technical workshops related to the installation, operation, and maintenance of small wind turbine applications targeting parties throughout the region interested in installing their own small wind turbines.

- Host as many educational events as the task budget allows at the site focusing on students from grade school through high school.

\section{TASK 2 - MULTISTATE TRANSMISSION COLLABORATIVE}

\section{Introduction}

As in many parts of the county, the electrical transmission system in the Great Plains region is operating under a significantly constrained state. The bottleneck condition impacts all new generation: fossil and renewables alike.

Many groups had been engaging stakeholders and convening meetings to understand the existing system and making new transmission capacity available. To name a few, the National Wind Coordinating Committee (NWCC) had been convening a group of stakeholders at a series of Upper Midwest Transmission Workshops; the Wind on the Wires (WOW) project had been working with the American Wind Energy Association (AWEA) and the Midwest Independent System Operator (MISO) to develop transmission planning that includes wind energy; and the Upper Great Plains Transmission Coalition (UGPTC) was formed to study new resource planning, specifically, a 600-MW coal-based facility and potentially $100 \mathrm{MW}$ of wind energy. In addition, several states, including North Dakota, South Dakota, Montana, and Minnesota, were debating legislation associated with the implementation of state transmission authorities. In North Dakota's case, the transmission authority would have the authority to bond, construct, own, and operate electrical transmission for the benefit of maximizing the development and utilization of the state's energy resources.

As an extension and compliment to existing efforts such as those described above, the EERC proposed to allocate a portion of this project's focus and budget toward helping move forward the agenda of finding or making new transmission capacity available, and as a result, aiding the installation of new, previously not possible, wind energy development. It was anticipated that some nominal amount of cost share would be generated in this task.

\section{Task 2 - Scope of Activities}

This task involved:

- Establishing a task goal that is consistent and complementary to the goals of the previously cited groups. 
- Creating an open line of communication with these groups to share information and identify partnering opportunities at the state and regional levels.

- Possible collaborating to continue existing transmission-related efforts and expand the base of knowledge through meetings, workshops, and the like.

\section{TASK 3 - WIND ENERGY FORECAST SYSTEM}

\section{Introduction}

If forecasts of energy generation could be done reliably and accurately, the owner/operators of wind turbines would be able to better estimate and schedule their future power production an hour, a day or, possibly, further into the future. This, in turn, would add to the value of wind energy and may increase its ability to better compete in the current electrical generation market.

Under this task, the EERC and Meridian Environmental Technology, Inc. (Meridian), proposed to develop and demonstrate the efficacy of an advanced wind energy forecast system (WEFS) for use in scheduling power output from wind farms. WEFS provided energy output forecasts for wind farms using the latest science in weather forecasting and Internet technology.

Cost share was provided for this task by Meridian in the form of several in-kind items totaling approximately $\$ 30,000$.

\section{Task 3 - Scope of Activities}

Meridian provided the first software component for the system. Instead of using a single weather model, Meridian statistically blended the output from multiple numerical weather prediction models to generate an optimal, unified forecast of wind and air density. Referred to as ensemble forecasting, this approach has been shown to consistently yield more reliable forecasts than any single-model approach because of its ability to capitalize on the proven individual strengths of the various models while also providing a mechanism for assessing the degree of uncertainty associated with each forecast.

WEFS required hourly forecasts for the following three atmospheric variables:

- Wind speed

- Wind direction

- Air density

These variables represented conditions for specific geographic locations and conditions at or near turbine hub height (50-100 meters) for at least the first 24 hours of the forecast period. Intermediate (24 to 48 hours) and long-term (48 to 120 hours) forecasts were also provided through WEFS. 
The second component to the system, the wind energy output model, produced wind farm energy forecasts. The EERC was responsible for developing the software for this model. Calculations were based on the following data inputs and parameters:

- Wind and air density forecasts

- Turbine wake loss

- Statistical analyses of the wind farm's performance history (factors in turbine performances and availabilities, etc.)

- Power curves for all turbine types located on the wind farm

The energy forecasts from the wind farm model were similar in intervals to the weather model. Hourly forecasts of potential energy generation were produced for at least the first 24 hours. Energy forecasts were also to extend beyond 24 hours.

The third software component, a GUI (graphical user interface), would take the wind energy forecast values and generate graphics that could be sent over the Internet and viewed on a Web browser by a wind farm operator.

\section{TASK 4 - ANALYSIS OF THE LONG-TERM ROLE OF HYDROGEN IN THE REGION}

\section{Introduction}

With increased interest in the production of hydrogen as a critical future energy source, many had viewed hydrogen produced from wind-generated electricity as an attractive option. In addition, many of the hydrogen production-related concepts involve utilization of energy resources without the need for additional electrical transmission. For this reason, the EERC proposed to provide a complete summary of end uses for hydrogen in the region, including transportation fuel, energy storage, nitrogen fertilizers, and many others.

Under this task, the EERC analyzed hydrogen as an energy carrier in contrast to energy delivered via the electrical transmission system. This included identifying the following:

- Types of transportation delivery systems

- Technical and economic barriers

- Potential market opportunities

- Alternative products (i.e., fertilizer)

- Lessons learned from international demonstrations

\section{Task 4 - Scope of Activities}

This task involved the following: 
- Examine and compile the currently proposed or active models in North America and Europe that involve hydrogen as an energy carrier

- Identify and prioritize first steps that will be necessary for development and promulgation of hydrogen usage in the Great Plains

\section{PROJECT ACTIVITIES}

\section{Task 1 - Small Wind Turbine Training Center}

This task involved the EERC creating a small wind turbine training center (SWTTC). The establishment of an SWTTC would allow EERC personnel to provide educational opportunities to a wide range of participants, including grade school- through college-level students and the general public. In addition, the facility would allow the EERC to provide technical training workshops related to the installation, operation, and maintenance of small wind turbines.

The SWTTC, located at the city of Grand Forks Public Safety Center in Grand Forks, North Dakota, currently consists of a single wind turbine, the Endurance S-250 on a 105-foot tiltup guyed tower. The S-250 is connected to the electrical grid on the "load side" of the electric meter, and the power produced by the wind turbine is consumed locally on the property.

In addition to the establishment of the SWTTC, the EERC hosted two small wind turbine workshops on May 18, 2010, and March 8, 2011, at the EERC in Grand Forks, North Dakota. The workshops were attended by a variety of attendees from North Dakota and Minnesota, numbering 40 and 27, respectively. Attendees heard presentations discussing the following topics as well as a question and answer session:

- Introduction, programs, incentives, and wind resource

- Wind turbine installation and maintenance

- Utility interconnection

With the SWTTC in place, the EERC will continue to seek opportunities to utilize the facility, educate the public, and provide research opportunities. Additionally, the EERC and the local utility will collect 1-minute production data and analyze these data for future research use. The Task 1 Final Report detailing the Task 1 activities is included in Appendix A.

\section{Task 2 - Multistate Transmission Collaborative}

Activities under this task involved the EERC collaborating with already well-established entities to aid in continued facilitation of transmission-related workshops.

Specifically, the EERC cosponsored, with the NWCC and others, the NWCC Western Transmission Workshop held July 18 and 19, 2006, in Denver, Colorado. This workshop focused on electrical transmission development in the western part of the country and developed next 
steps under the Western Governors' Association's Clean and Diversified Energy Advisory Committee recommendations.

In addition, the EERC cosponsored, with the NWCC and others, the Midwest Transmission Workshop held December 2006 in Minneapolis, Minnesota.

The EERC also assisted in planning the Midwest Transmission Workshop held on November 29 and 30, 2007, in Sioux Falls, South Dakota. As in the past, this workshop convened utility industry representatives, renewable energy advocates, electrical transmission system managers, and legislative and regulatory leaders to work through the onerous issues related to electrical transmission in the Midwest.

\section{Task 3 - Wind Energy Forecasting Systems}

The EERC and Meridian developed and demonstrated the efficacy of WEFS for use in scheduling energy output from wind farms for a regional electrical generation and transmission utility (Utility X). The original proposal stated that WEFS would consist of three components: 1) a numerical weather prediction model(s), 2) a wind energy output model, 3) and a GUI. The final design actually melded the first two components together, and the third component was changed from a Web-based GUI to an e-mail-based interface.

WEFS uses ensemble modeling to produce meteorological forecast data. Artificial intelligence software ingests these forecasts along with historical data on wind farm performance and historical weather data to predict energy output. WEFS was developed and tested for a subject wind farm within Utility X's control area. The subject wind farm consisted of twentyseven 1.5-MW wind turbines spread out over 10 square miles.

WEFS was able to outperform climatology and the average capacity factor for the wind farm over the first 108 hours, or 4.5 days, of the forecast. The system performs the best during the first 36 hours of the forecast, with an average mean absolute error (MAE) of $17 \%$ of the wind farm's capacity (i.e., 40.5 MW). MAEs increased with longer lead times to 31\% at Forecast Hour 168. Maximum errors increased with time and ranged from $-42 \%(+47 \%)$ to $-87 \%(+92 \%)$. Inaccuracy in the weather forecasts account for a large portion of the errors. However, wind farm power production can be inconsistent with the wind resource at the time and contribute to the size of the forecast error.

WEFS was compared to the forecast system in place at Utility X. As of the spring of 2006, Utility $\mathrm{X}$ received wind forecasts from a reputable industry leader in weather forecasting. These weather forecasts were converted into energy forecasts using technical information about the wind turbines. WEFS and Utility $X$ forecasts were scaled by installed capacities. Results indicate that Utility X's systemwide forecasts performed slightly better than WEFS's forecasts for the subject wind farm. The Task 3 Final Report is included in Appendix B. 


\section{Task 4 - Analysis of the Long-Term Role of Hydrogen in the Region}

With increased interest in the production of hydrogen as a critical future energy source, many have viewed hydrogen produced from wind-generated electricity as an attractive option. In addition, many of the hydrogen production-related concepts involve utilization of energy resources without the need for additional electrical transmission.

For this reason, the Task 4 Final Report (Appendix C) provided a summary of end uses for hydrogen in the region and focused on one end product in particular (fertilizer), including several process options and related economic analyses.

It is important to note that the Task 4 Final Report was prepared as part of a larger multitask project. During the course of the project, this task (and the resulting report) was performed early in the overall project time line; therefore, the time-sensitive information included in this report, especially in the "Summary of International Activities" Section, is very dated. Unfortunately, the budget did not allow for an update of the information to be included.

The Task 4 Final Report analyzed the role of hydrogen in the region, including an examination of the following:

- Summary of international activities

- Identification of hydrogen uses in the region

- Potential market opportunities

- Technical and economic barriers 
APPENDIX A

\section{TASK 1 - SMALL WIND TURBINE TRAINING CENTER FINAL REPORT}




\title{
SMALL WIND TURBINE TRAINING CENTER
}

\author{
Final Report \\ Prepared for: \\ Keith Bennett \\ U.S. Department of Energy \\ 1617 Cole Boulevard \\ Golden, CO 80401
}

Agreement No. DE-FG36-05G085037

Prepared by:

Brad G. Stevens, P.E.

Energy \& Environmental Research Center University of North Dakota 15 North 23rd Street, Stop 9018 Grand Forks, ND 58202-9018 


\section{DOE DISCLAIMER}

This report was prepared as an account of work sponsored by an agency of the United States Government. Neither the United States Government, nor any agency thereof, nor any of their employees, makes any warranty, express or implied, or assumes any legal liability or responsibility for the accuracy, completeness, or usefulness of any information, apparatus, product, or process disclosed, or represents that its use would not infringe privately owned rights. Reference herein to any specific commercial product, process, or service by trade name, trademark, manufacturer, or otherwise does not necessarily constitute or imply its endorsement, recommendation, or favoring by the United States Government or any agency thereof. The views and opinions of authors expressed herein do not necessarily state or reflect those of the United States Government or any agency thereof.

\section{NDIC DISCLAIMER}

This report was prepared by the Energy \& Environmental Research Center (EERC) pursuant to an agreement partially funded by the Industrial Commission of North Dakota, and neither the EERC nor any of its subcontractors nor the North Dakota Industrial Commission nor any person acting on behalf of either:

(A) Makes any warranty or representation, express or implied, with respect to the accuracy, completeness, or usefulness of the information contained in this report or that the use of any information, apparatus, method, or process disclosed in this report may not infringe privately owned rights; or

(B) Assumes any liabilities with respect to the use of, or for damages resulting from the use of, any information, apparatus, method, or process disclosed in this report.

Reference herein to any specific commercial product, process, or service by trade name, trademark, manufacturer, or otherwise does not necessarily constitute or imply its endorsement, recommendation, or favoring by the North Dakota Industrial Commission. The views and opinions of authors expressed herein do not necessarily state or reflect those of the North Dakota Industrial Commission

\section{EERC DISCLAIMER}

LEGAL NOTICE This research report was prepared by the EERC, an agency of the University of North Dakota, as an account of work sponsored by the U.S. Department of Energy. Because of the research nature of the work performed, neither the EERC nor any of its employees makes any warranty, express or implied, or assumes any legal liability or responsibility for the accuracy, completeness, or usefulness of any information, apparatus, product, or process disclosed or represents that its use would not infringe privately owned rights. Reference herein to any specific commercial product, process, or service by trade name, trademark, manufacturer, or otherwise does not necessarily constitute or imply its endorsement or recommendation by the EERC. 


\section{ACKNOWLEDGMENTS}

This report was prepared with the support of the U.S. Department of Energy (DOE) National Energy Technology Laboratory Cooperative Agreement No. DE-FG36-05G085037. However, any opinions, findings, conclusions, or recommendations expressed herein are those of the authors(s) and do not necessarily reflect the views of DOE. 


\section{TABLE OF CONTENTS}

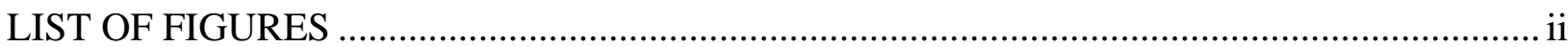

LIST OF TABLES ............................................................................................................. ii

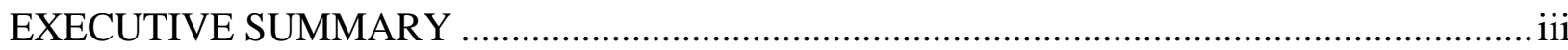

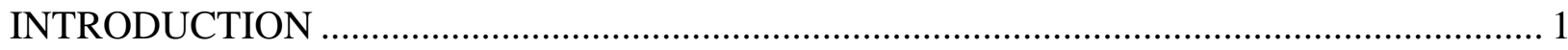

Scope of Activities .................................................................................................. 1

Task 1 - Site Selection and Development .................................................................. 1

Task 2 - Equipment Procurement and Installation.................................................... 1

Task 3 - Education and Outreach ................................................................ 2

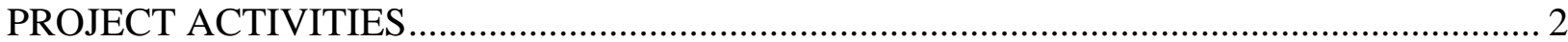

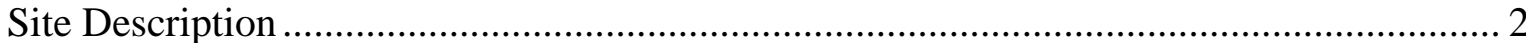

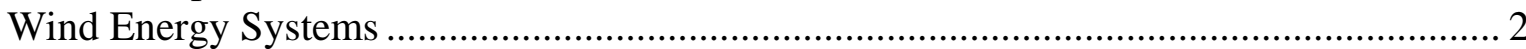

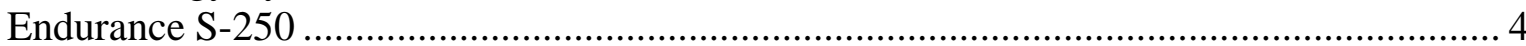

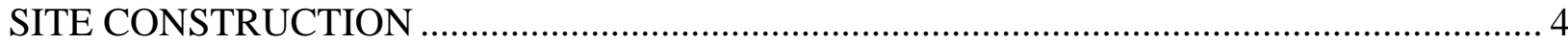

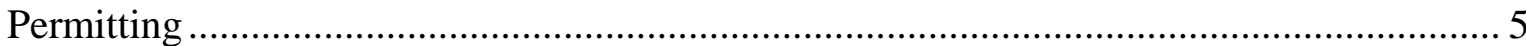

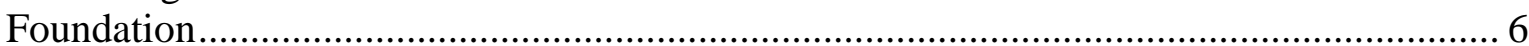

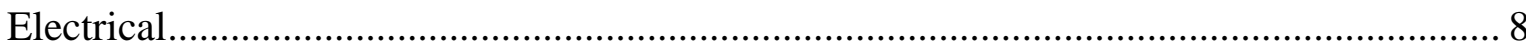

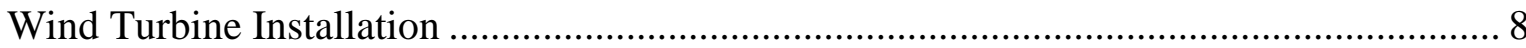

Wind Turbine Commissioning ........................................................................................... 10

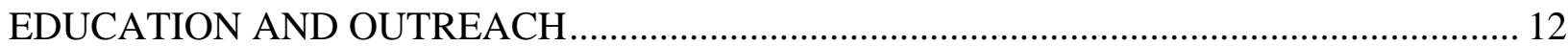

FINAL DEMOGRAPHICS ....................................................................................ppendix A 


\section{LIST OF FIGURES}

1 Small wind turbine training center wind turbine location............................................ 3

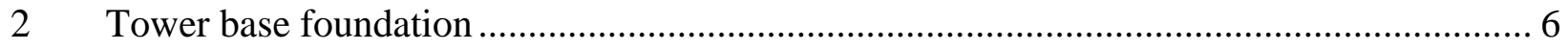

3 Winch anchor foundation .................................................................................... 7

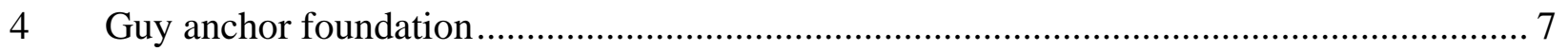

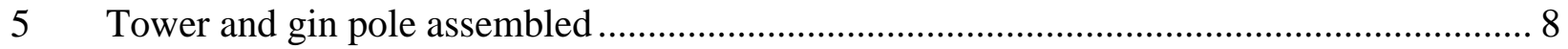

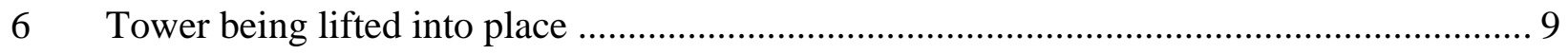

$7 \quad$ Tower fully erected and guy wires tensioned........................................................... 9

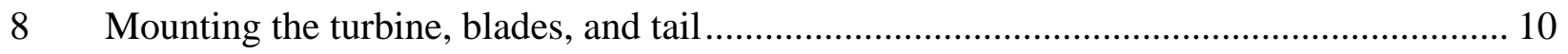

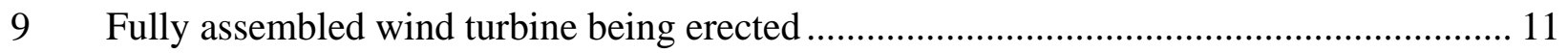

10 Wind turbine installation complete ....................................................................... 11

\section{LIST OF TABLES}

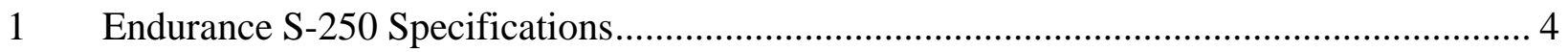




\section{SMALL WIND TURBINE TRAINING CENTER}

\section{EXECUTIVE SUMMARY}

The Energy \& Environmental Research Center (EERC) created a small wind turbine training center (SWTTC) to allow EERC personnel to provide educational opportunities to a wide range of participants including grade school- through college-level students and the general public. In addition, the facility has allowed the EERC to provide technical training workshops related to the installation, operation, and maintenance of small wind turbines.

The SWTTC, located at the city of Grand Forks Public Safety Center in Grand Forks, North Dakota, currently consists of a single wind turbine, the Endurance S-250, on a 105-foot tilt-up guyed tower. The S-250 is connected to the electrical grid on the "load side" of the electric meter, and the power produced by the wind turbine is consumed locally on the property.

In addition to the establishment of the SWTTC, the EERC hosted two small wind turbine workshops on May 18, 2010, and March 8, 2011, at the EERC in Grand Forks, North Dakota. The workshops were attended by a variety of attendees from North Dakota and Minnesota numbering 40 and 27, respectively. Attendees heard presentations discussing the following topics and participated in a question and answer session:

- Introduction, programs, incentives, and wind resource

- Wind turbine installation and maintenance

- Utility interconnection

With the SWTTC in place, the EERC will continue to seek opportunities to utilize the facility to educate the public and provide research opportunities. Additionally, the EERC and the local utility will collect 1-minute production data and analyze these data for future research use. 


\section{SMALL WIND TURBINE TRAINING CENTER}

\section{INTRODUCTION}

Based on conversations with personnel from the U.S. Department of Energy (DOE) and the continued need to educate the public about wind energy, the Energy \& Environmental Research Center (EERC) proposed to modify the original Task 1 scope of activities in DOE Award No. DE-FG36-05GO85037 to establish a small wind turbine training center (SWTTC).

The establishment of an SWTTC allowed EERC personnel to provide educational opportunities to a wide range of participants including grade school- through college-level students and the general public. In addition, the facility allowed the EERC to provide technical training workshops related to the installation, operation, and maintenance of small wind turbines.

As summarized below, the proposed activities involved 1) the selection and development of a suitable wind turbine site, 2) procurement and installation of equipment, and 3) an educational component. Conceptually, the EERC was to install up to three small wind turbines ranging in size from 1.8 to $20 \mathrm{~kW}$ (due to budgetary constraints the number of turbines was reduced to one 5-kW turbine) at the site and host up to two technical workshops.

\section{Scope of Activities}

\section{Task 1 - Site Selection and Development}

- Identify and prioritize potential sites for development of the SWTTC.

- Select a site based on land ownership, site access, electrical interconnection access, proximity to Grand Forks, availability of wind resource (i.e., openness, absence of obstructions), and other characteristics.

- Submit necessary permits and secure site development approval from appropriate governing bodies, including the following:

- City of Grand Forks

- North Dakota Historical Society

- Nodak Electric Power Cooperative

- Federal Aviation Administration

- Grand Forks Airport Authority

\section{Task 2 - Equipment Procurement and Installation}

- Identify up to three potential small wind turbines to be installed at the SWTTC.

- Identify and procure necessary electrical infrastructure to interconnect the wind turbines.

- Negotiate with vendors for the purchase and delivery of a single small wind turbine.

- Negotiate with local contractors for the installation of electrical infrastructure. 
- Negotiate with local contractors for the installation of the necessary wind turbine foundation.

- Install foundation, wind turbine, and associated electrical infrastructure at the site.

\section{Task 3 - Education and Outreach}

- Host up to two technical workshops related to the installation, operation, and maintenance of small wind turbine applications targeting parties throughout the region interested in installing their own small wind turbines.

\section{PROJECT ACTIVITIES}

\section{Site Description}

Based on input from representatives of the city of Grand Forks during several meetings, the EERC and the city of Grand Forks have agreed to install the wind turbine on the grounds of the Grand Forks Public Safety Center west of Grand Forks in the Grand Forks Industrial Park (Figure 1). The legal description is Township 151 North, Range 50 West, Section 7, Southwest $1 / 4$. Several other sites were considered during the evaluation process including the following:

- Adjacent to the city of Grand Forks clearwell facility

- On the grounds of the proposed Wellness Center

- The new city of Grand Forks solid waste landfill site in Rye township

- The area near a city of Grand Forks water tower adjacent to I-29 and north of Gateway Avenue

- City of Grand Forks lift station locations on the edge of town

Some permitting work had been completed by the EERC for siting the wind turbine at the clearwell facility when the turbine location was moved to the Public Safety Center location.

\section{Wind Energy Systems}

Two wind turbines were identified as potential turbines to install at the SWTTC, the Endurance Wind Power, Inc. (Endurance), S-250 and the Southwest Windpower, Inc., Skystream. Due to budgetary constraints, only one turbine was selected, and that was the Endurance S-250. 
EERC BS43090.CDR

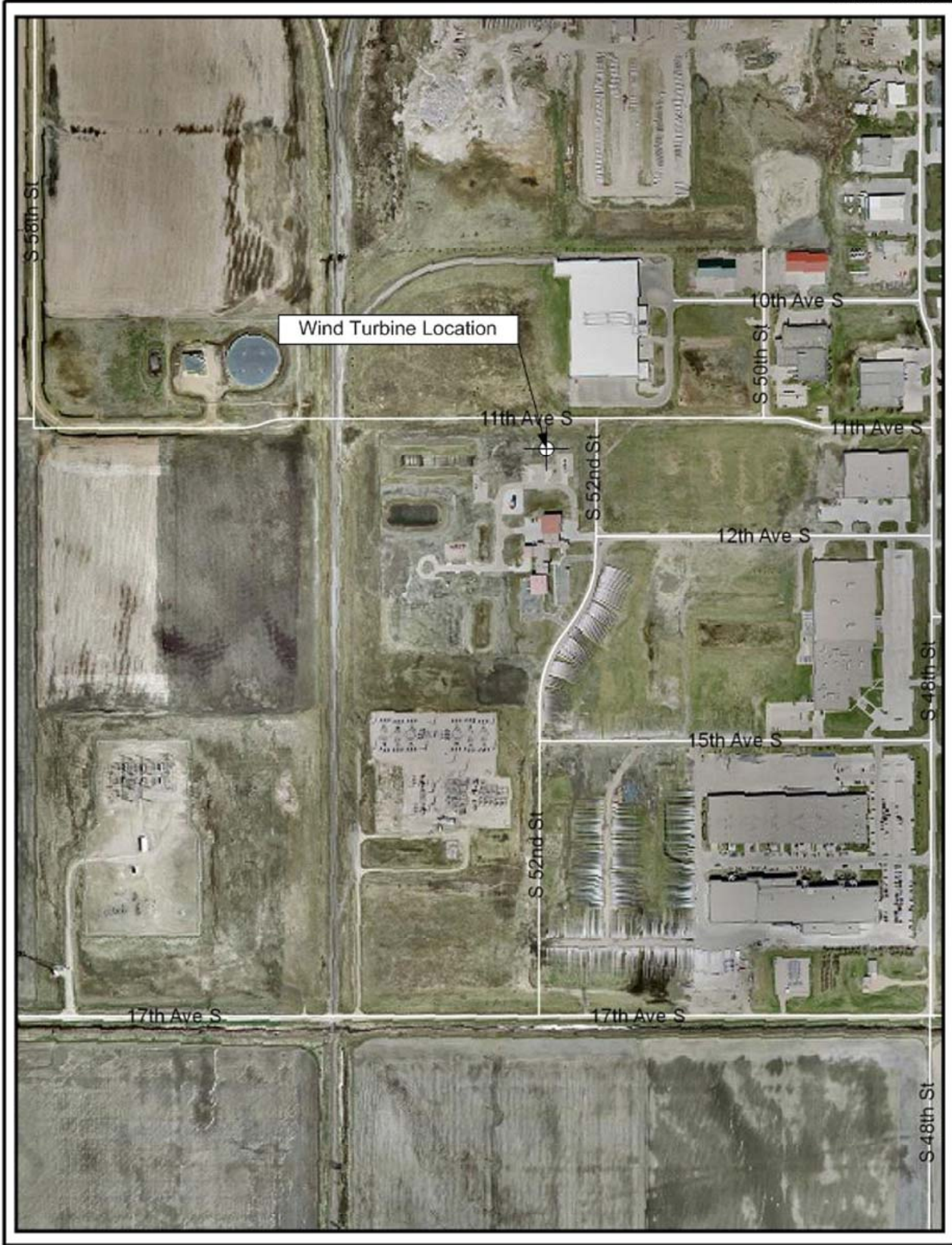

Figure 1. Small wind turbine training center wind turbine location. 


\section{Endurance S-250}

The S-250, manufactured by Endurance, is a three-bladed, upwind, horizontal-axis wind turbine with a maximum electrical output of $5.0 \mathrm{~kW}$ at $14 \mathrm{~m} / \mathrm{s}$ hub-height wind speed. Endurance S-250 specifications are shown in Table 1.

Similar to utility-scale wind turbines, the S-250 utilizes an induction generator to produce grid-quality AC power without the use of an inverter. Typical small wind turbines use a permanent magnet configuration. To improve electrical production efficiency, the S-250 employs a dual-voltage switching system that allows the generator to produce 120 volts AC at low wind speeds and 240 volts AC at higher wind speeds. Voltage switching is accomplished with the control system and software, which also prevents excessive voltage switching in variable winds. The S-250 wind turbine features dual, redundant braking systems that can be activated either by the system controls or by the operator in any wind conditions. Several tower heights are available, ranging from 63 to 126 feet. The tower height to be utilized at the SWTTC was a 105-feet guyed tilt-up tower.

\section{SITE CONSTRUCTION}

All site construction activities were coordinated and supervised by the EERC. Activities included but were not limited to the following:

- Securing all necessary permits and approvals

- Locating utilities prior to on-site construction

- Coordination with city of Grand Forks personnel

- Coordination and supervision of foundation installation

- Coordination and supervision of wind turbine installation

- Coordination and supervision of electrical infrastructure installation

Table 1. Endurance S-250 Specifications

\begin{tabular}{lll}
\hline Description & \multicolumn{1}{c}{ SI Units } & \multicolumn{1}{c}{ English Units } \\
\hline Blade Length & $2.56 \mathrm{~m}$ & $8.67 \mathrm{ft}$ \\
Rotor Diameter & $5.5 \mathrm{~m}$ & $18 \mathrm{ft}$ \\
Swept Area & $23.8 \mathrm{~m}^{2}$ & $256 \mathrm{ft}^{2}$ \\
Cut-in Speed & $4.2 \mathrm{~m} / \mathrm{s}$ & $9.4 \mathrm{mph}$ \\
Cutout Speed & $24 \mathrm{~m} / \mathrm{s}$ & $54 \mathrm{mph}$ \\
Rated Speed & $10.7 \mathrm{~m} / \mathrm{s}$ & $24 \mathrm{mph}$ \\
Rated Power (at rated speed) & $4.25 \mathrm{~kW}$ & $4.25 \mathrm{~kW}$ \\
Estimated Annual Production & $11,000 \mathrm{kWh}$ & $11,000 \mathrm{kWh}$ \\
\hline
\end{tabular}




\section{Permitting}

\section{U.S. Department of Energy}

Since funding from DOE was used in the project, the EERC was required to submit necessary documentation to secure approval under the National Environmental Policy Act of 1969.

\section{City of Grand Forks}

The city of Grand Forks required several documents including the following:

- Site construction document

- Site access agreement

- Building permit

- Electrical inspection certificate

\section{Electric Utility}

The proposed location of the wind energy facility is served by Nodak Electric Cooperative (Nodak), which obtains its electricity from Minnkota Power Cooperative. At the direction of Nodak, the wind turbine was connected on the load side of the utility meter. This allowed the city's Public Safety Center to consume any electricity produced by the wind turbine instead of putting the electricity directly on the electrical grid. Nodak required an interconnection application.

\section{$\underline{\text { Air Traffic }}$}

Since the clearwell facility was the original site of choice, EERC personnel had several conversations with entities and agencies responsible for the safety of airspace and control of flight operations in the proposed site, including the Federal Aviation Administration (FAA), the Grand Forks International Airport, and the University of North Dakota John D. Odegard School of Aerospace Sciences.

Although it was not required, the EERC submitted to the FAA a "Notice of Proposed Construction or Alteration" (Form 7460-1). On July 20, 2008, the EERC received a "Determination of No Hazard to Air Navigation" from the FAA regarding the three proposed structures (two wind turbines and one meteorological tower).

Based on several conversations with representatives from the Grand Forks International Airport and the University of North Dakota, no objection to the proposed wind turbine installations were posed.

Upon moving the location of the wind turbine to the location described above, the EERC did not resubmit the FAA forms (as it is not required). The EERC did discuss the new location with the Grand Forks International Airport and the University of North Dakota John D. Odegard 
School of Aerospace Sciences, but since this site is even further from the airport, no objections are expected.

\section{$\underline{\text { Other }}$}

In addition, approval was required from the State Historical Society of North Dakota and the Grand Forks Historical Preservation Committee to verify that the project did not impact any historically sensitive areas.

\section{Foundation}

The S-250 required a fairly substantial foundation. Figures 2, 3, and 4 show the foundation for the tower base, winch anchor point, and guy anchor point, respectively.

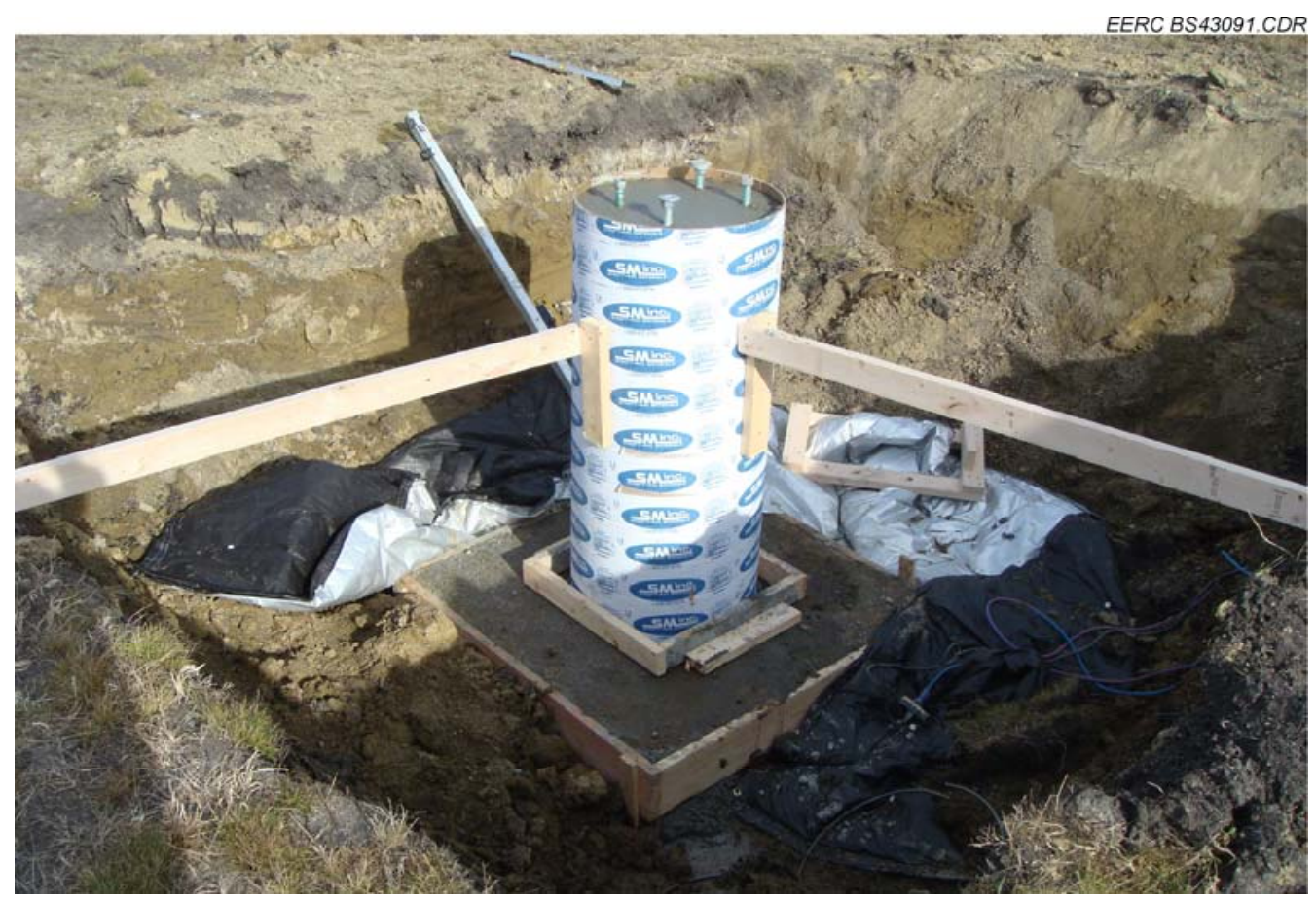

Figure 2. Tower base foundation. 


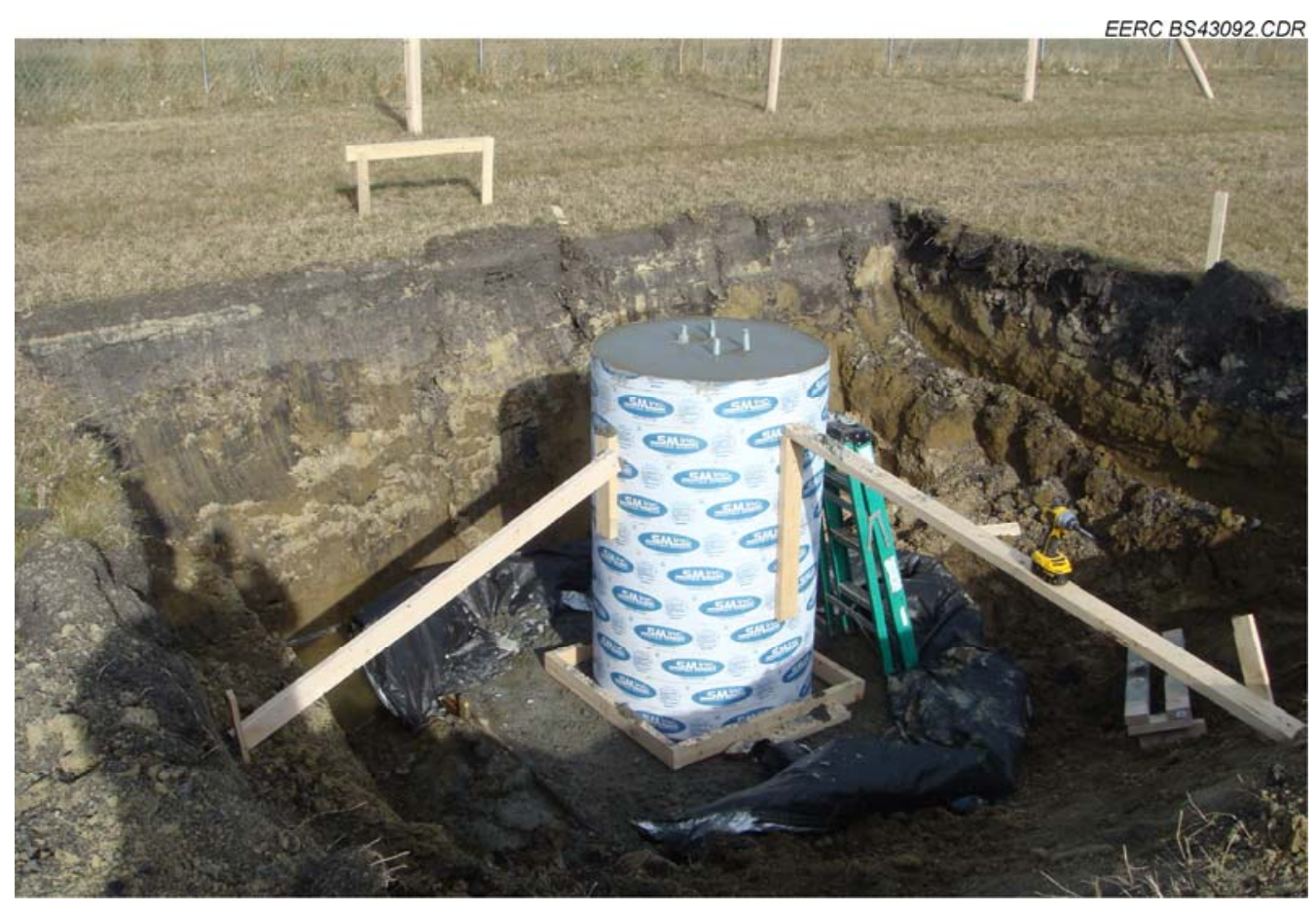

Figure 3. Winch anchor foundation.

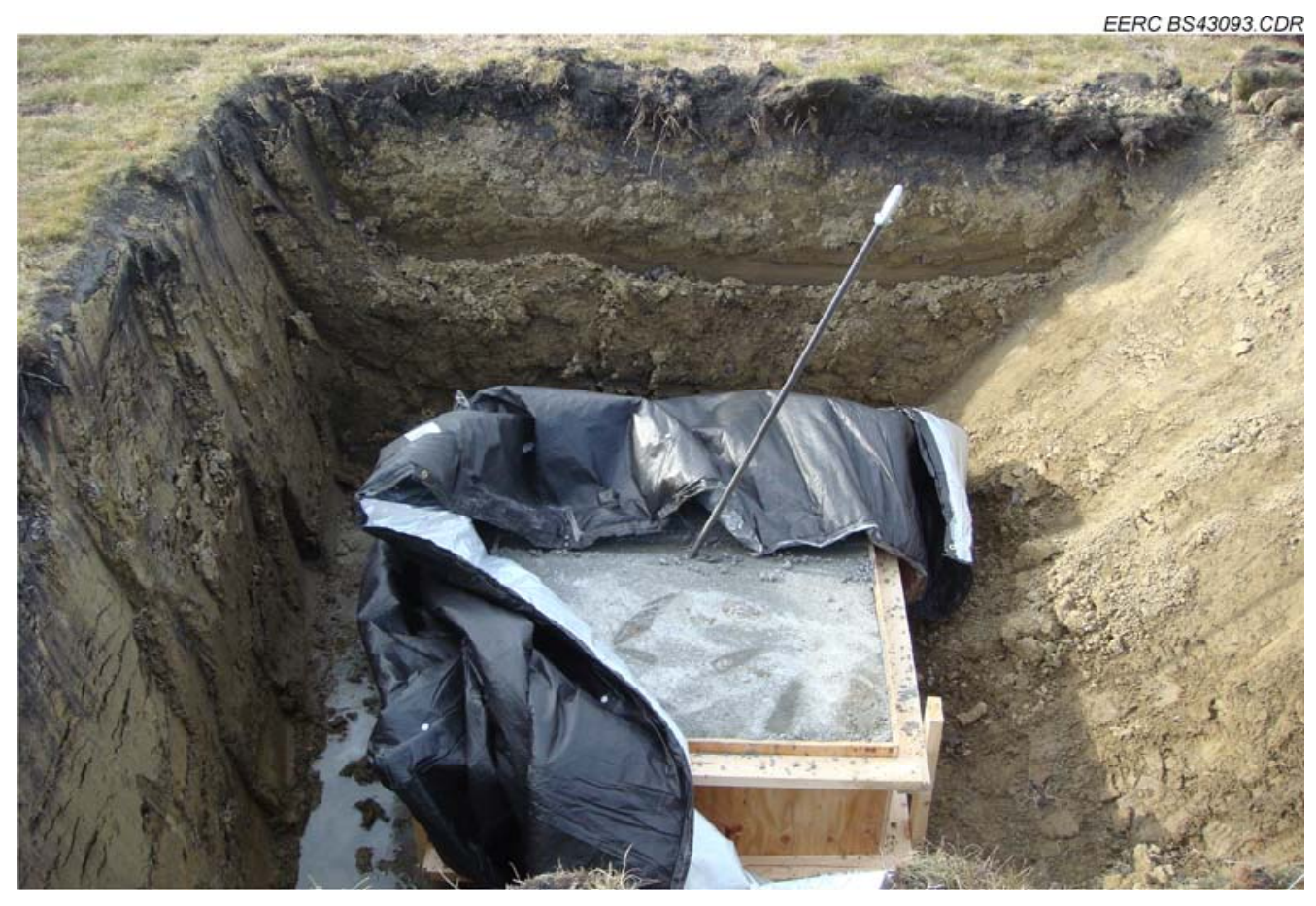

Figure 4. Guy anchor foundation. 


\section{Electrical}

Since Nodak desired to have the wind turbine electrically connected on the load side of the meter, EERC personnel coordinated with city of Grand Forks personnel to obtain and review the electrical configuration of the Public Safety Center and determine the necessary electrical infrastructure to interconnect the wind turbine. The S-250 was electrically connected to an existing service at the Public Safety Center. Although convenient, this interconnection point posed some challenges. Most significant was the fact that the service was a single-phase service fed from a three-phase system at the main building. For this reason, the voltage at the connection panel was 208 volts (actually measured to be 213 volts). To get the voltage, both directions, within allowable ranges, required a transformer be installed between the interconnection point and turbine control panel. Because of the long lead time required for an isolation transformer, the use of a different type of transformer known as a buck/boost transformer was attempted.

\section{Wind Turbine Installation}

On December 20, 2011, Endurance personnel arrived at the EERC to perform several upgrades to the wind turbine prior to installation. These upgrades took 1 day to perform. On December 21, 2011, personnel from Endurance, the EERC, and Enterprise Sales Company (turbine maintenance provider) performed the assembly (Figure 5) and erection of the wind turbine tower without the turbine mounted on the tower (Figures 6 and 7). This lift was done to perform proper guy wire tensioning and allow for tower straightening.

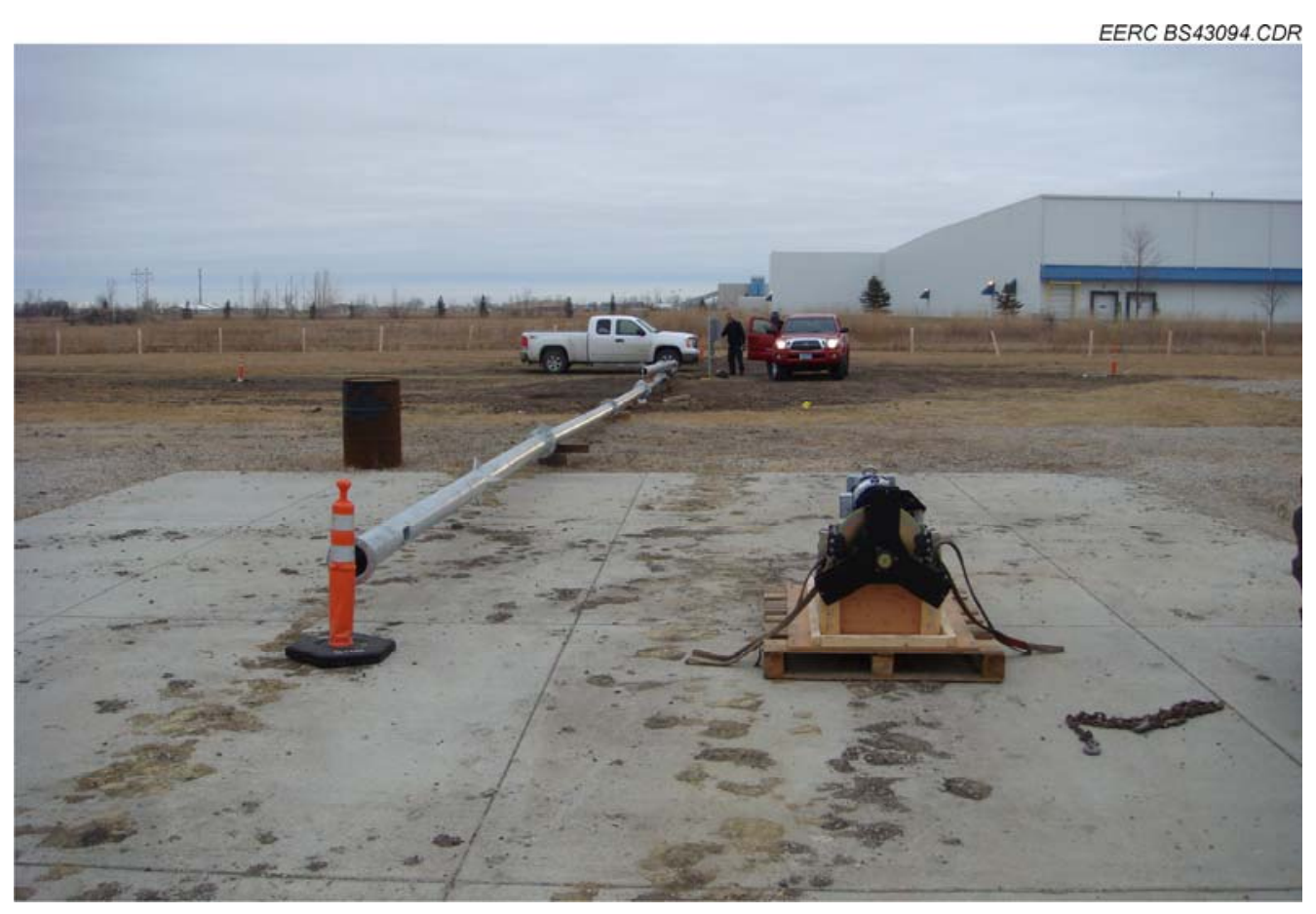

Figure 5. Tower and gin pole assembled. 


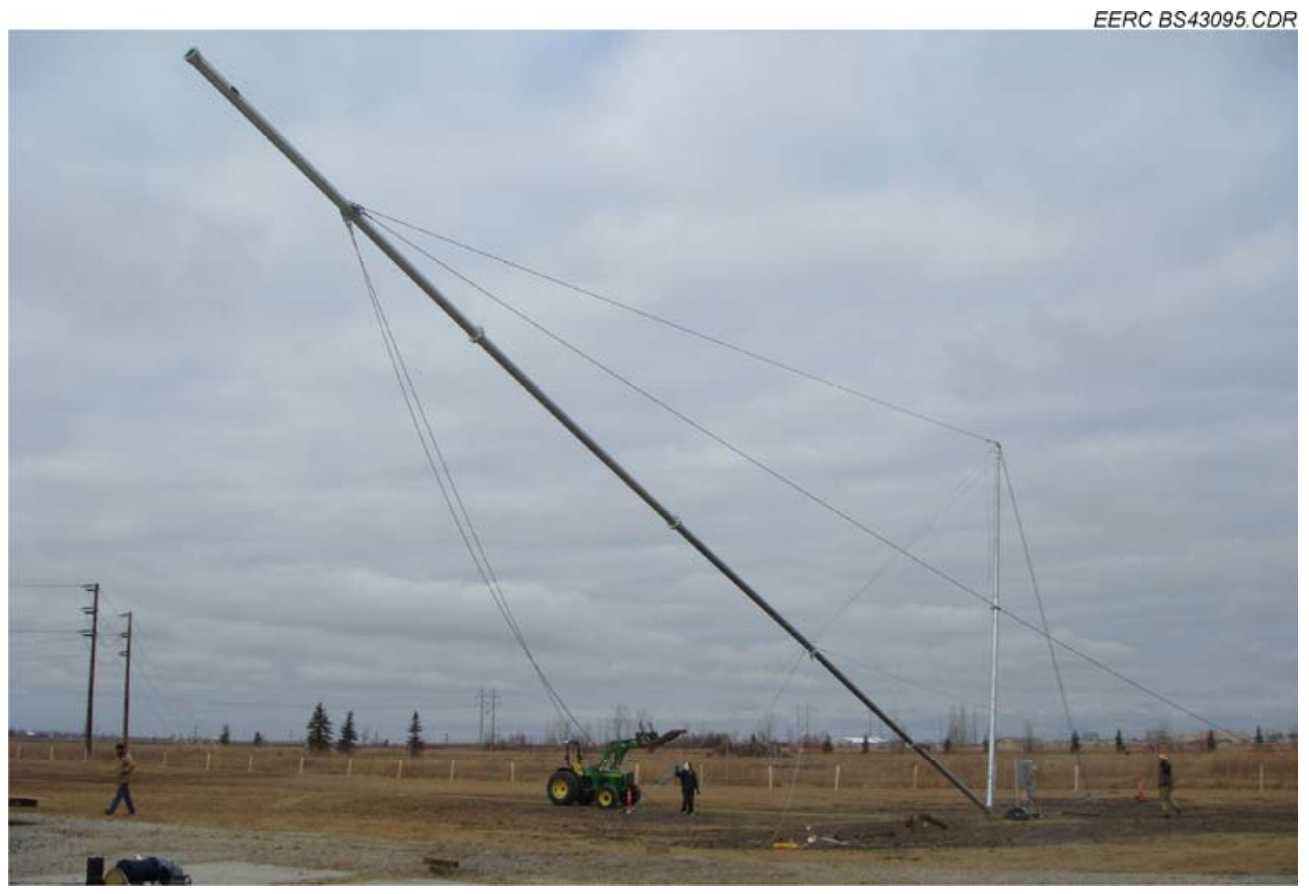

Figure 6. Tower being lifted into place (without turbine mounted).

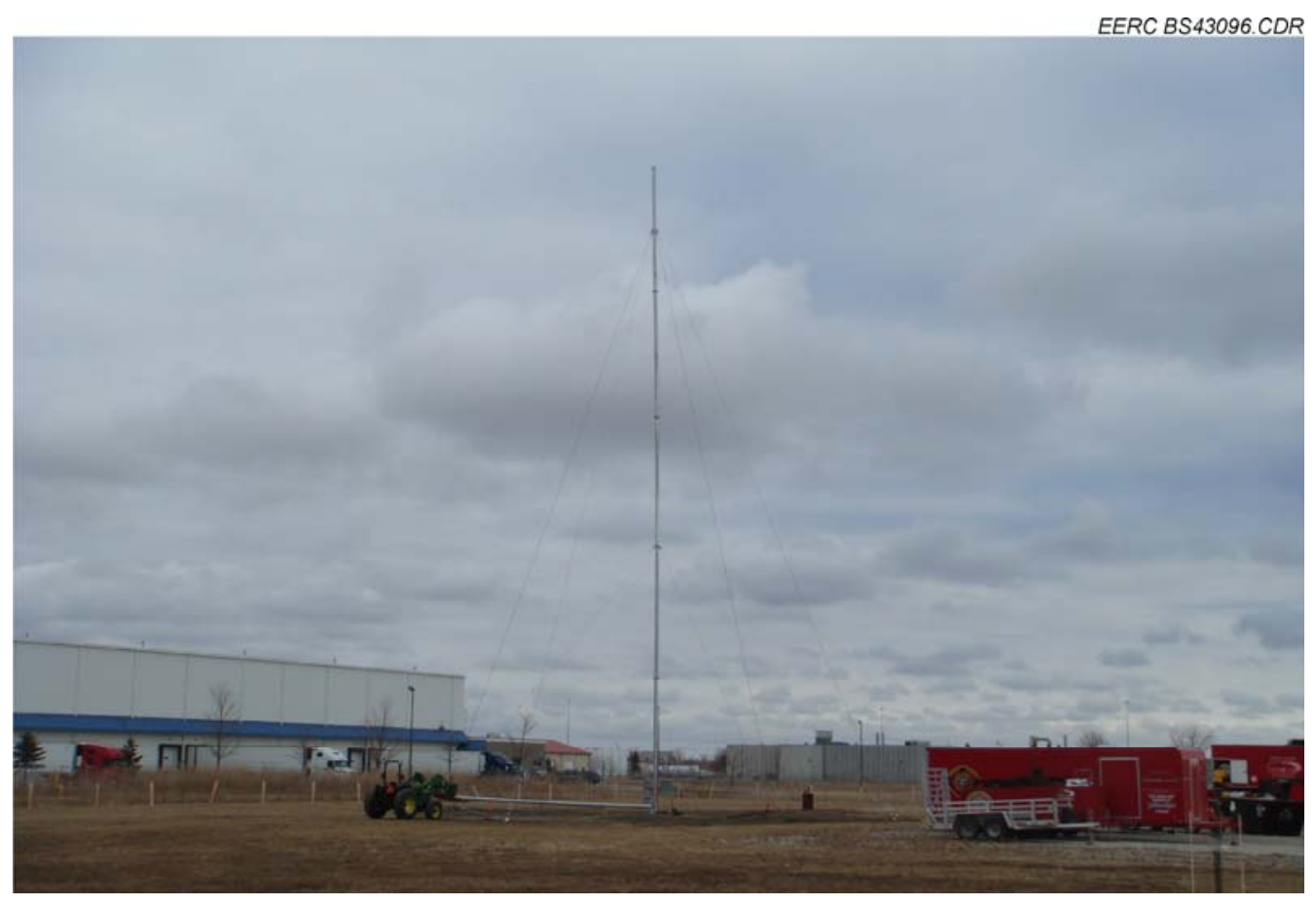

Figure 7. Tower fully erected and guy wires tensioned. 
On December 22, 2011, the tower was lowered, and the wind turbine was mounted on the tower top (Figure 8). The electrical cabling was installed in the tower, and the tower (with turbine mounted) was lifted for the final time. Figures 9 and 10 show the wind turbine fully assembled, being lifted into place, and ready for commissioning.

\section{Wind Turbine Commissioning}

Once the wind turbine was erected, the tower straightened, and the electrical wiring completed, the commissioning process began. Unfortunately, only at this stage of the installation were we able to determine that the buck/boost transformers were not able to regulate the voltage to within an allowable range for the wind turbine control panel.

At the time of this writing (and the end of the contract period), an isolation transformer has been ordered and should be installed during the first week of January 2012. After the transformer is installed, the final commissioning will be completed, and the wind turbine will be put into service. The remaining work will be performed with supplemental funding from the North Dakota Division of Community Services.

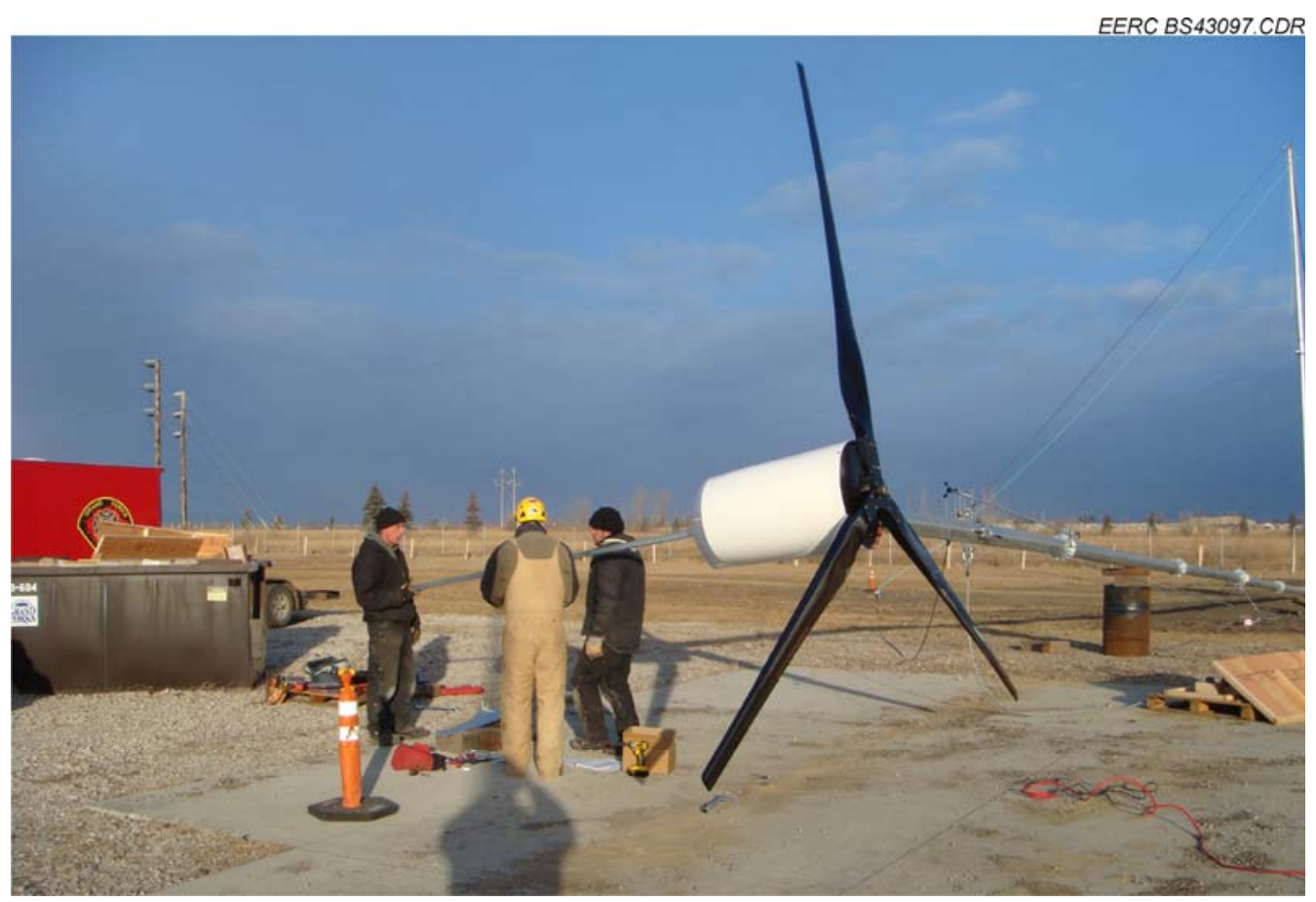

Figure 8. Mounting the turbine, blades, and tail. 


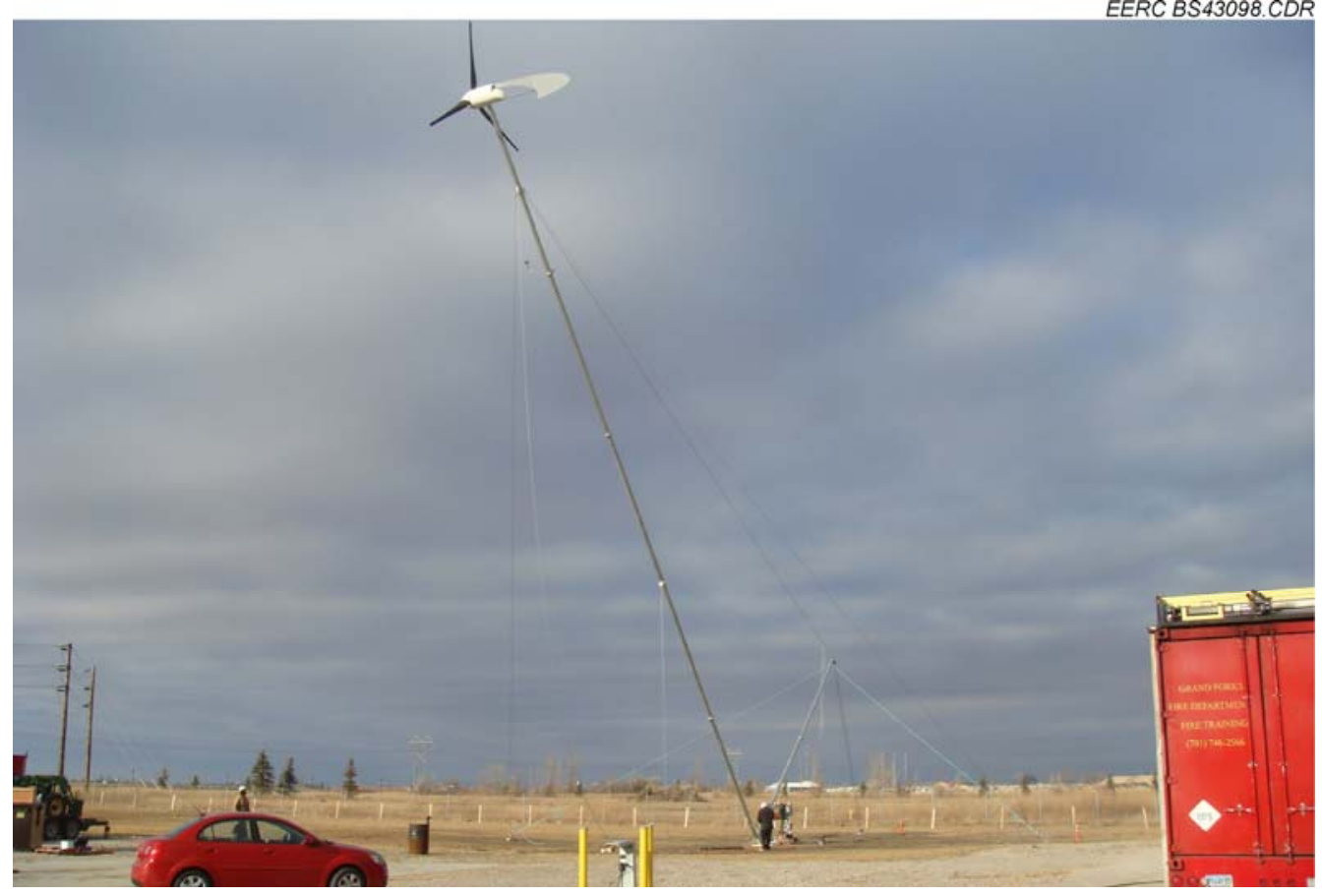

Figure 9. Fully assembled wind turbine being erected.

EERC BS43099.CDR

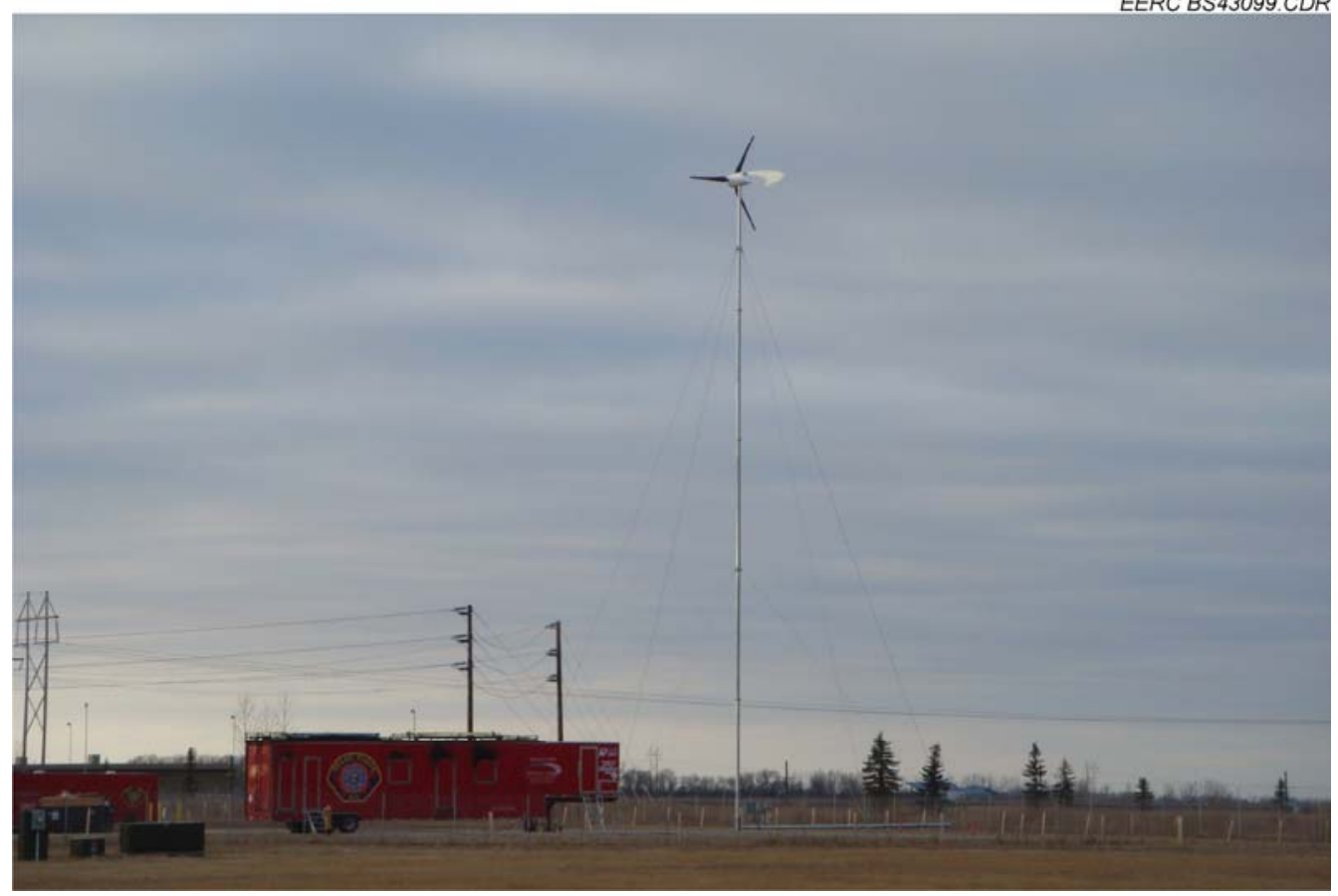

Figure 10. Wind turbine installation complete. 


\section{EDUCATION AND OUTREACH}

As indicated in the introduction section, Subtask 3 involved hosting up to two workshops to educate individuals regarding small wind turbine technology.

The first workshop was held on May 18, 2010, at the EERC in Grand Forks, North Dakota. During the half-day workshop, 40 attendees from North Dakota and Minnesota heard presentations discussing the following topics as well as a question and answer session:

- Introduction, programs, incentives, and wind resource

- Wind turbine installation and maintenance

- Utility interconnection

The second workshop, also at the EERC, was held on March 8, 2011. Again this workshop was a half-day and was attended by 27 people from North Dakota and Minnesota. The same topics were presented in the second workshop. Final demographics for each workshop are provided in Appendix A. 
APPENDIX A FINAL DEMOGRAPHICS 


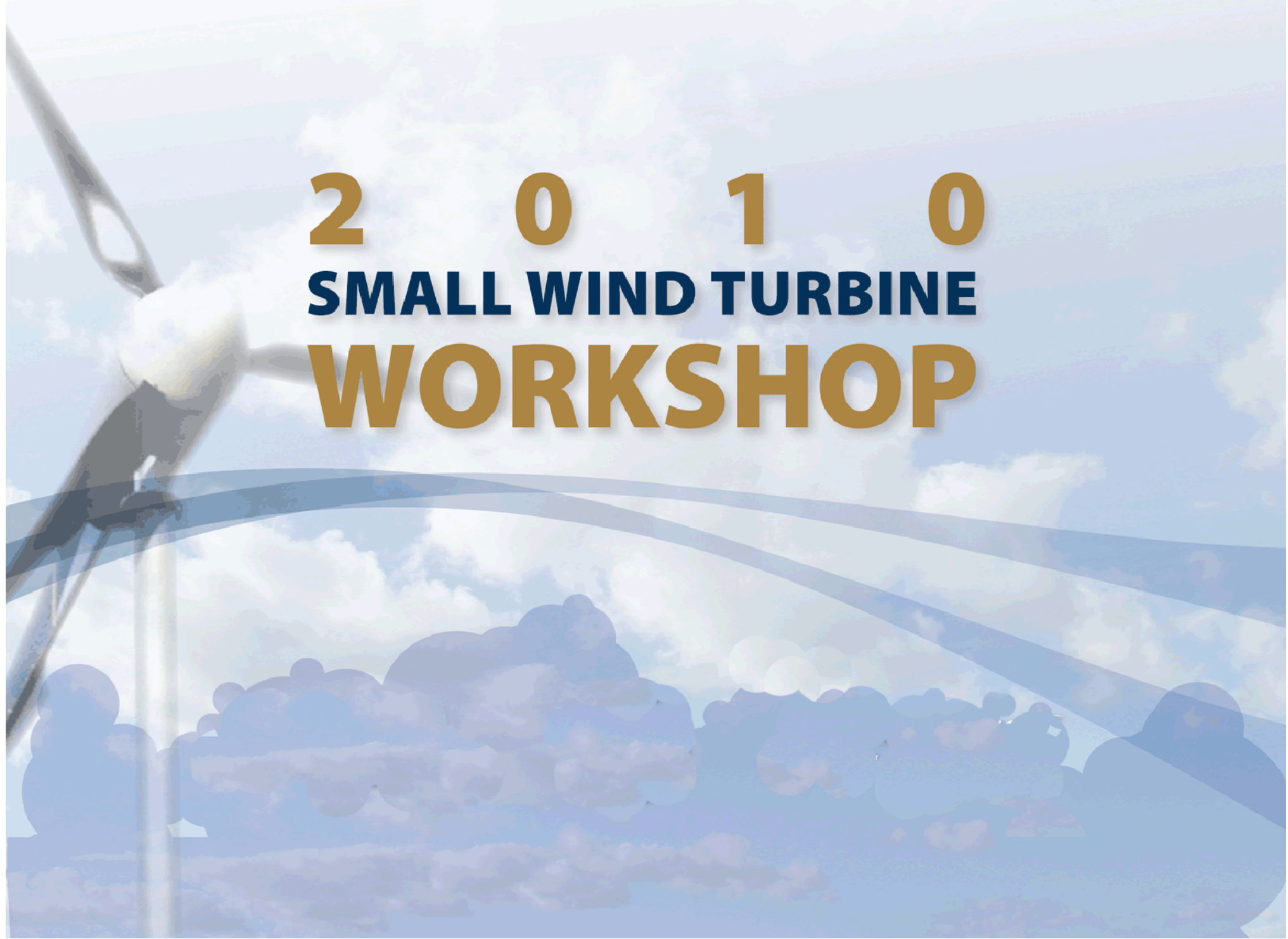

\section{Final Demographic Report}

Distributed by LaRae Foerster

Outreach and Communications Data Coordinator 


\section{Small Wind Turbine Workshop Registrants/Attendees}

Total Registrations Received: 44

Participating Organizations: 23

Number of States: 2

\section{Attendee Affiliations}

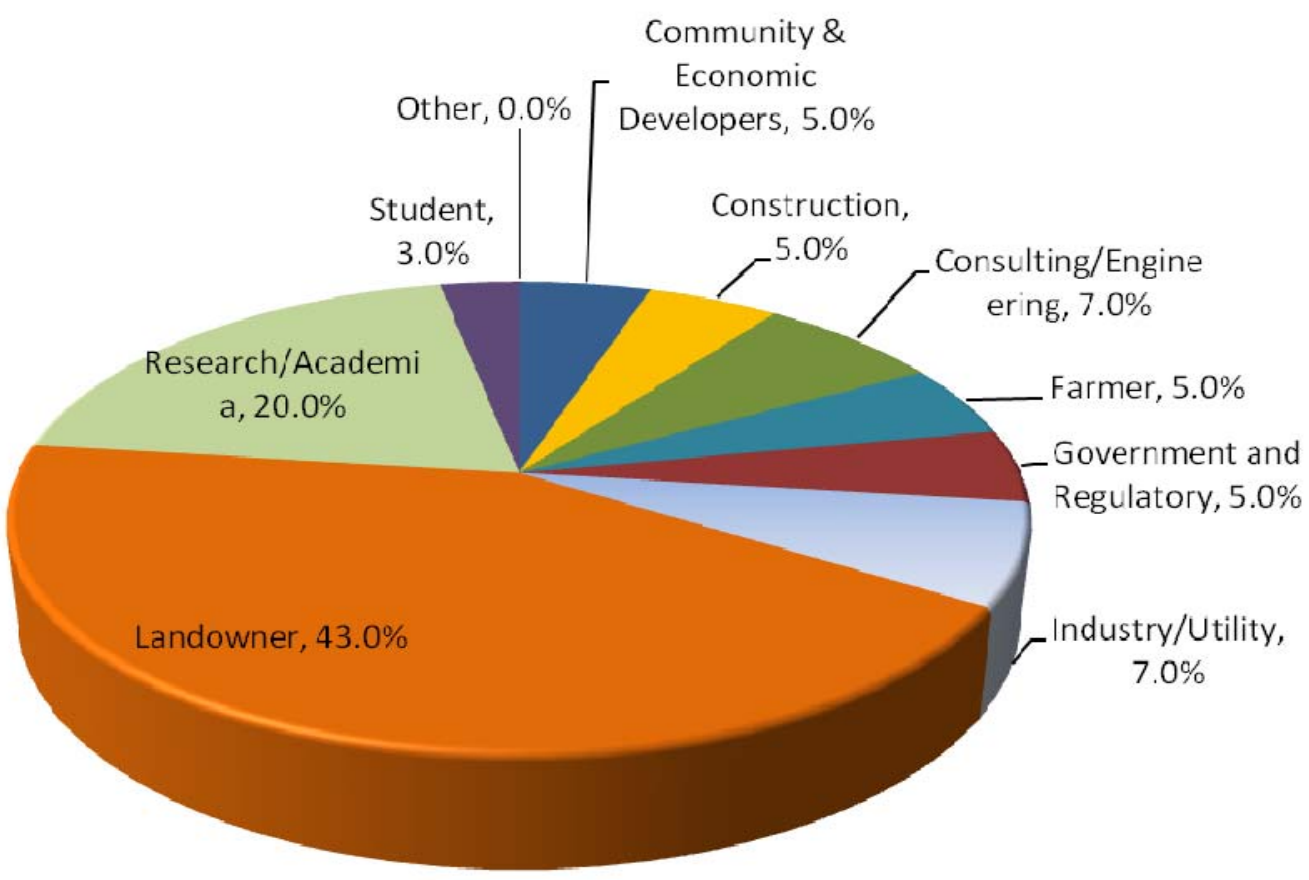

\begin{tabular}{|c|l|c|c|}
\hline$\square$ & Community \& Economic Developers & $5.0 \%$ & 2 \\
\hline$\square$ & Construction & $5.0 \%$ & 2 \\
\hline$\square$ & Consulting/Engineering & $7.0 \%$ & 3 \\
\hline$\square$ & Equipment Vendor & $0.0 \%$ & 0 \\
\hline$\square$ & Farmer & $5.0 \%$ & 2 \\
\hline$\square$ & Government and Regulatory & $5.0 \%$ & 2 \\
\hline$\square$ & Industry/Utility & $7.0 \%$ & 3 \\
\hline$\square$ & Landowner & $43.0 \%$ & 17 \\
\hline$\square$ & Research/Academia & $20.0 \%$ & 8 \\
\hline$\square$ & Student & $3.0 \%$ & 1 \\
\hline$\square$ & Other & $0.0 \%$ & 0 \\
\hline & Total & $\mathbf{1 0 0 \%}$ & $\mathbf{4 0}$ \\
\hline
\end{tabular}




\section{States}

North Dakota - 25

Minnesota - 15

\section{Participating Organizations}

\section{Organizations}

AquaGen, Inc.

Arvig Communications Systems

Bemidji State University

City of Grand Forks

CSMS Camp Ripley

EERC

Flying S Ranch

Giziibii RC\&D

IBEW Local Union 1426

ICS (dba Industrial Contract Services), Inc.

IDA Corporation

Job Service North Dakota

Minnesota Department of Health

New Horizon Resort

Nodak Electric Power Cooperative, Inc.

Northwest Minnesota Foundation

Red River Valley Co-op Power

Sanford

$s f(x)$ Engineering, Inc.

SFM Group

UND Aerospace

University of Minnesota

University of North Dakota 


\section{0 \\ SMALL WIND TURBINE WOPKSHOP \\ 르를}

\section{EVALUATION SUMMARY}

\section{Evaluations Returned - 63\%}

\section{Please rate the following workshop presentations:}

Programs, Incentives, and Wind Resource

Excellent (7) Good (18)

Wind Turbine Installation and Maintenance

Excellent (12) Good (13)

Utility Interconnection

Excellent (3)
Good (15)
Fair (0)

Poor (0)

N/A (0)

Fair (0)

Poor (0)

N/A (0)

Fair (5)

Poor (0)

N/A (2)

\section{Please rate the workshop overall:}

Needs Improvement
1(1) $2(1)$
$3(0)$
$4(0)$
$5(1)$
$6(1)$
7 (9)
$8(8)$
$9(3)$
$10(0)$

Excellent

Comments:

- Nice facilities, easy to see and hear.

- Pretty good workshop. Was geared more toward individuals wanting towers rather than what regulations to follow.

- Some areas vague.

\section{What information was most useful to you and why?}

- Overall cost and process.

- Protocol references.

- Installation, cost justification.

- The hands-on from Joe of Avon, Minnesota.

- Joe Straley. Small business owner, knows his stuff, lays his cards face up on the table.

- Joe Straley info and Q\&A - Hands on what is involved with wind towers.

- Installation.

- Specific, objective (mostly) information about equipment, costs, etc., based on experience.

- Interesting to know more about the interconnection.

- All general info.

- Installation and maintenance. Want to know what is needed and how much work is needed for upkeep.

- All information on turbines-prices, maintenance, cost-sharing info. 
- Wind turbine maintenance and tax breaks.

- Installation information.

- Wind speed and economics.

- Joe Straley - practical, costs

\section{What topics would you like to see added/deleted from the Small Wind Turbine Workshop?}

- $\mathrm{n} / \mathrm{a}$

- Delete the electric guy. He was confusing and didn’t directly answer questions.

- Run some actual example situations showing all considerations, some example equipment, etc. Start to finish, costs, payback, etc.

- More info on wind electric systems under $\$ 20,000$.

- More info. concerning the setup and operation of small wind turbines.

- More info on how turbines affect other landowners. How to regulate turbines.

- Add costs from for small residential turbines. Add typical cost for various sizes. Add equipment sources, prices, etc.

- Nothing

- If sticking to small wind, need more info about costs, land info regarding sq ft required (estimate) for given project.

- More zoning issues/noise ordinances, etc.

- Go through various models available and compare them: Bergey versus Jacobs versus Vestas versus small 3$5 \mathrm{~kW}$ models.

- Add more detailed information on installation, turbine models and brand comparison, and operation and maintenance.

\section{Overall, the level of information presented was:}

Too Technical (1) Challenging (1) Appropriate (21) Too General (2) N/A (0)

Comments:

- Some terminology and acronyms were used and not explained - maybe assuming too much given the introductory nature of the workshop.

\section{Please rate the quality of the workshop materials packet:}
Excellent (4)
Good (20)
Fair (1)
Poor (0)
N/A (0)

Comments:

- $\$ 40$ probably saved me thousands.

- Appreciate the overhead copies. 
7. Please rate the workshop registration process:
Excellent (18)
Good (5)
Fair (0)
Poor (0)
N/A (2)

Comments:

- Online didn’t work.

\section{Please rate the on-site workshop staff assistance:}
Excellent (16)
Good (7)
Fair (0)
Poor (0)
N/A (2)

Comments:

\section{Please rate the following items regarding workshop facilities:}
A. Refreshment Break. Excellent (12) Good (10) Fair (1) Poor (0) N/A (2)
B. Meeting Room Excellent (21) Good (2) Fair (0) Poor (0) N/A (2)

\section{How did you first learn about this workshop?}

(6) Postcard from the EERC

(6) E-mail from the EERC

(4) Colleague

(0) Web site

(3) Newspaper

- GF Herald day prior to workshop

(2) N/A

(4) Other (please list)

- UND Newsletter

- Work

- Through CERTS (MN)

- Wife works at UND - Informed me

- UND e-newsletter

\section{Do you have any other suggestions for how we could improve this workshop?}

- Additional reference materials, maybe.

- As workshops go - this was informative!

- $\quad$ Expand - show more info on actual systems in use.

- More advertising, ask IBEW and NECA* to join in presenting, check on senators and congressmen for future incentives.

- Split workshop into wind generators (turbine owners) and wind regulators (city officials).

- Hard to hear even in second row (first two presentations.)

- Typical cost breakdown for various sizes with towers and equipment, etc.

- Perhaps more on costs $/ \mathrm{kW}$, land required for representative system, when photovoltaic systems may be used rather than wind energy (cost effective).

- Visit an actual tower/turbine.

- More information on small wind turbine manufacturers.

- Make it a full day. 
*International Brotherhood of Electrical Workers and National Electrical Contractors Association.

Thank you for taking the time to complete this form; your comments are appreciated. Please turn in your form at the workshop registration desk.

Note: If completing the form following the workshop, please fax to (701) 777-5181. 


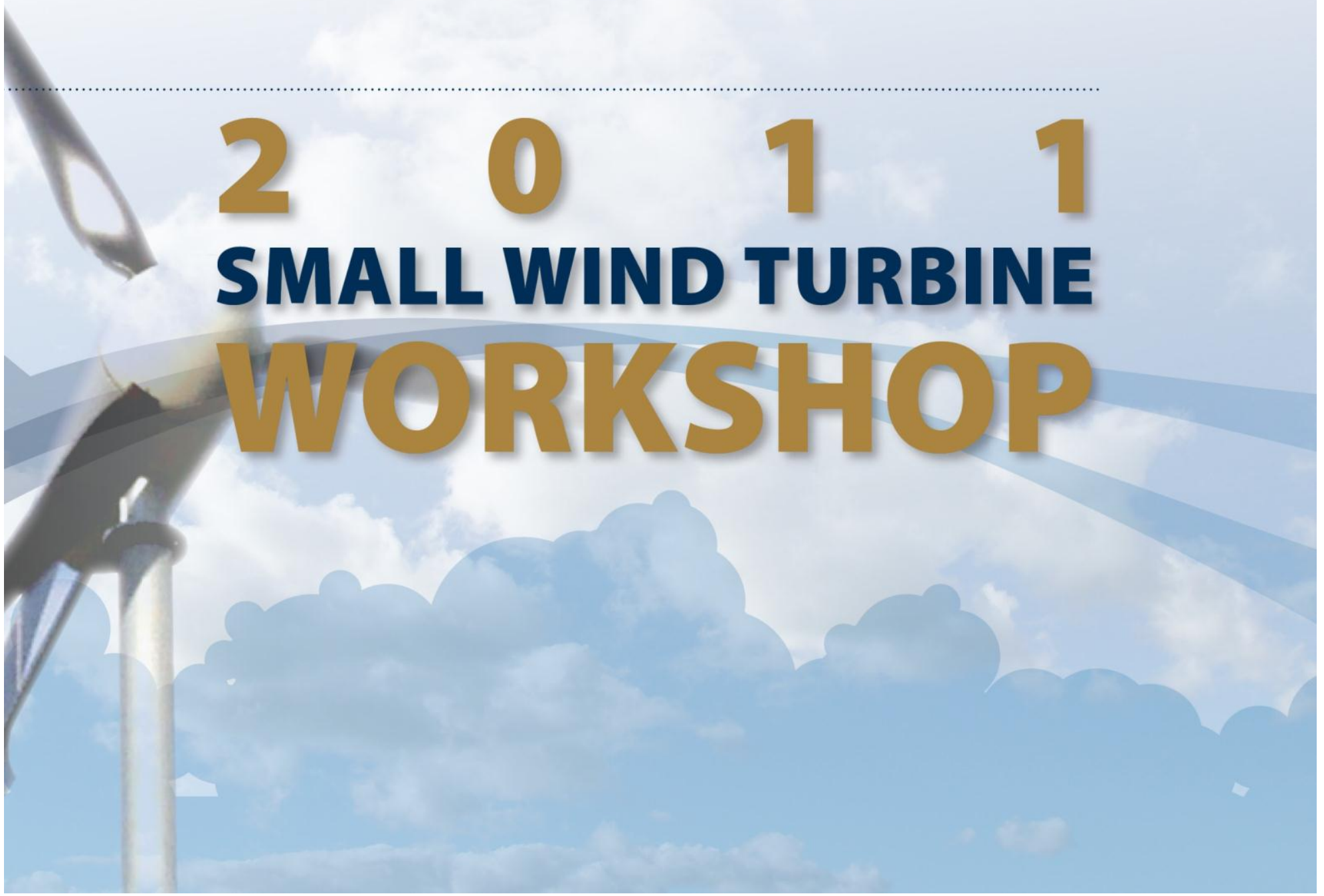

\section{Final Demographic Report}

Distributed by Kari Gagner

Communications Specialist and Event Coordinator 


\section{Small Wind Turbine Workshop Registrants/Attendees}

Total Registrations Received: 28

No Shows: 1

Total Attendees: 27

Participating Organizations: 16

Number of States: 2

\section{Attendee Affiliations}

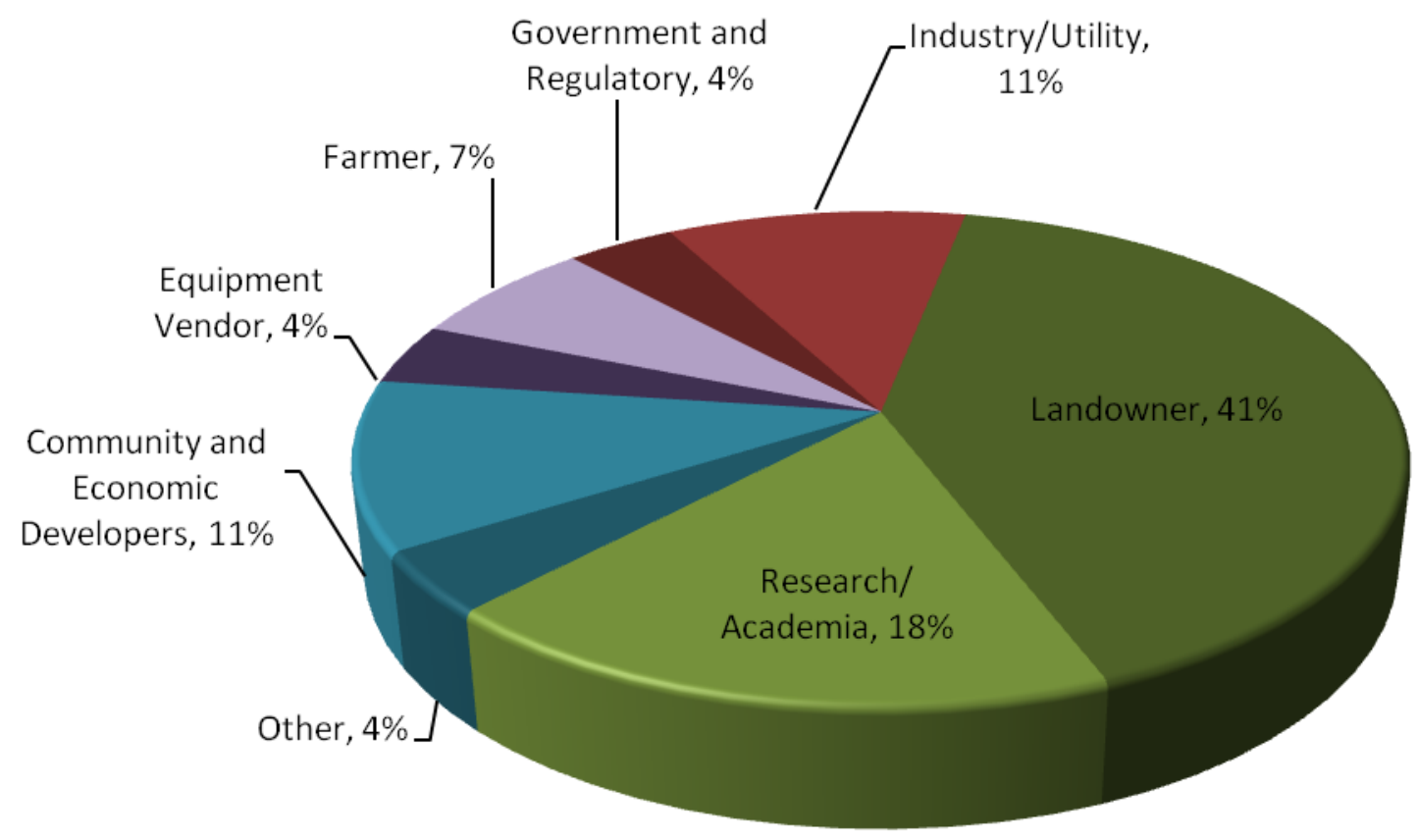

\begin{tabular}{|c|l|r|c|}
\hline$\square$ & Community and Economic Developers & $11 \%$ & 3 \\
\hline$\square$ & Construction & $0 \%$ & 0 \\
\hline$\square$ & Consulting/Engineering & $0 \%$ & 0 \\
\hline$\square$ & Equipment Vendor & $4 \%$ & 1 \\
\hline$\square$ & Farmer & $\mathbf{7 \%}$ & 2 \\
\hline$\square$ & Government and Regulatory & $4 \%$ & 1 \\
\hline$\square$ & Industry/Utility & $11 \%$ & 3 \\
\hline$\square$ & Landowner & $41 \%$ & 11 \\
\hline$\square$ & Research/Academia & $18 \%$ & 5 \\
\hline$\square$ & Student & $0 \%$ & 0 \\
\hline & Other & $4 \%$ & 1 \\
\hline & Total & $\mathbf{1 0 0 \%}$ & $\mathbf{2 7}$ \\
\hline
\end{tabular}




\section{States}

North Dakota - 21

Minnesota -6

\section{Participating Organizations}

\section{Organizations}

Bemidji State University

Center For Innovation

Dahlgren \& Company Inc.

Dakota Turbines Inc.

EERC

Heinle Industries

Minnesota State University Moorhead

North Dakota State University Extension Service

Nodak Electric Power Cooperative, Inc.

North Dakota Department of Commerce

Rolla Job Development Authority

Serkland Law Firm

Solar and Wind Energy Consultants, LLC

University of Minnesota Extension

University of North Dakota Department of Technology

Yellow Dart Industries 


\section{List of Workshop Participants}

\section{Participants}

David Bahr, Bemidji State University

Ray Bauer

Neal Buttke

Jay Fisher, Yellow Dart Industries

Gordon Graetz

Lonnie Greenlee, Dahlgren \& Company Inc.

Jack Hanson, Solar and Wind Energy Consultants, LLC

Ron Haugen, North Dakota State University Extension Service

Lyle Heinle, Heinle Industries

Yong Hou, University of North Dakota

Keith A. Jacobson

Alex Johnson, University of North Dakota

Jerry Kaml

Frank Lewandowski

Keith Monson, Dakota Turbines Inc.

Joe Murphy, North Dakota Department of Commerce

Art Nash, University of Minnesota Extension Service

Jill Olson

Jason Rayner

Blaine Rekken, Nodak Electric Power Cooperative, Inc.

Mark D. Sanderson, Minnesota State University Moorhead

Marilyn Schlosser

Bradley Stevens, EERC

Richard Sutcliffe

Jib Wilson, EERC

George Youngerman, Rolla Job Development Authority 


\section{EVALUATION SUMMARY}

\section{Evaluations Retuned - 66\%}

\section{Please rate the following workshop presentations:}

Programs, Incentives, and Wind Resource
Excellent (5)
Good (9)
Fair (4)
Poor (0)
N/A (0)

Wind Turbine Installation and Maintenance

Excellent (3) Good (9)

Fair (5) $\quad$ Poor (1) N/A (0)

Utility Interconnection
Excellent (5)
Good (9)
Fair (2)
Poor (0)
N/A (2)

\section{Please rate the workshop overall:}

Needs Improvement
$1(0)$
$2(0)$
$3(0)$
$4(1)$
$5(1)$
$6(2)$
$7(6)$
$8(3)$
$9(1)$

Excellent

Comments:

- Only commented on feeding the grid and how to make money. No discussion on how to stay off the grid and do a whole system off-grid, e.g., what type of turbine, storage, solar combo.

\section{What information was most useful to you and why?}

- What systems are in use.

- Would have been good to include city regulations and more of a step-by-step how to and who to see. Feel it addressed commercial or larger systems more than residential.

- Good overview.

- Blain Rekken from Nodak.

- Networking.

- Cost and how it affects me.

- Tax incentives and granting.

- Provided a good overall explanation of this process.

- Programs and Incentives helps with feasibility determination.

- General overall information.

- Utility interconnection. 
4. What topics would you like to see added/deleted from the Small Wind Turbine Workshop?

- Suppliers that have systems to show their systems.

- I would like to see the "small wind" address more "in town" systems rather than just farms. Installation and Maintenance section was poor - rambling...

- None.

- More on type and workings of different types of turbine, more on the side of cost and technology in producing electricity in a system of self-sustainability. What new technology or improvements in wind.

- Add more economics.

- Property tax issues.

- Specifics on small/individual use turbines.

- Some update on legislative changes - maybe someone from the U.S. Department of Energy or the Department of Commerce.

- More detail or costs of small wind and solar systems and maintenance and operation systems.

- How to install wind generators yourself.

- No recommendations.

\section{Overall, the level of information presented was:}

Too Technical (0) Challenging (2) Appropriate (12) Too General (4) N/A (0)

Comments:

6. Please rate the quality of the workshop materials packet:
Excellent (3)
Good (15)
Fair (0)
Poor (0)
N/A (0)

Comments:

\section{Please rate the workshop registration process:}

$\begin{array}{llll}\text { Excellent (9) } & \text { Good (7) } & \text { Fair (0) } & \text { Poor (0) }\end{array}$

Comments:

- Very efficient - good use of name tags.

8. Please rate the on-site workshop staff assistance:

$\begin{array}{lllll}\text { Excellent (9) } & \text { Good (6) } & \text { Fair (0) } & \text { Poor (0) } & \text { N/A (3) }\end{array}$

Comments:

9. Please rate the following items regarding workshop facilities:

A. Refreshment Break .............................. Excellent (9) Good (5) Fair (1) Poor (0) N/A (3)

B. Meeting Room ................................... Excellent (9) Good (6) Fair (0) Poor (0) N/A (3)

- Beautiful facility! 
10. How did you first learn about this workshop?

(5) Postcard from the EERC

(6) E-mail from the EERC

(2) Colleague

(0) Web site

(3) Newspaper

(2) N/A

(2) Other (please list):

- County Extension Rep.

- Wife works for the EERC.

- Was on your list for years and finally got to attend.

11. Do you have any other suggestions for how we could improve this workshop?

- If possible, a vendor show.

- None.

- Have vendors on-site.

- I felt Jack Hanson's remarks, from time-to-time, needed some upgrading for a group presentation.

- No. I enjoyed the workshop very much. I appreciate the networking opportunity also. Thank you!

Thank you for taking the time to complete this form; your comments are appreciated. Please turn in your form at the workshop registration desk.

Note: If completing the form following the workshop, please fax it to (701) 777-5181. 
APPENDIX B

\section{TASK 3 - WIND ENERGY-FORECASTING SYSTEM (WEFS) FINAL REPORT}




\section{TASK 3 - WIND ENERGY-FORECASTING SYSTEM (WEFS)}

Final Report

(for the period of June 1, 2005, through March 31, 2011)

Prepared for:

Keith Bennett

U.S. Department of Energy

Golden Field Office

1617 Cole Boulevard

Golden, CO 80401-3393

Agreement No. DE-FG36-05GO85037

Prepared by:

Troy K. Simonsen

Brad G. Stevens

Energy \& Environmental Research Center University of North Dakota 15 North 23rd Street, Stop 9018

Grand Forks, ND 58202-9018 


\section{DISCLAIMERS}

This report was prepared as an account of work sponsored by an agency of the United States Government. Neither the United States Government, nor any agency thereof, nor any of their employees makes any warranty, express or implied, or assumes any legal liability or responsibility for the accuracy, completeness, or usefulness of any information, apparatus, product, or process disclosed or represents that its use would not infringe privately owned rights. Reference herein to any specific commercial product, process, or service by trade name, trademark, manufacturer, or otherwise does not necessarily constitute or imply its endorsement, recommendation, or favoring by the United States Government or any agency thereof. The views and opinions of authors expressed herein do not necessarily state or reflect those of the United States Government or any agency thereof.

\section{ACKNOWLEDGMENTS}

This report was prepared with the support of U.S. Department of Energy (DOE) Cooperative Agreement No. DE-FG36-05GO85037. However, any opinions, findings, conclusions, or recommendations expressed herein are those of the authors(s) and do not necessarily reflect the views of DOE.

\section{EERC DISCLAIMER}

LEGAL NOTICE This research report was prepared by the Energy \& Environmental Research Center (EERC), an agency of the University of North Dakota, as an account of work sponsored by DOE. Because of the research nature of the work performed, neither the EERC nor any of its employees makes any warranty, express or implied, or assumes any legal liability or responsibility for the accuracy, completeness, or usefulness of any information, apparatus, product, or process disclosed or represents that its use would not infringe privately owned rights. Reference herein to any specific commercial product, process, or service by trade name, trademark, manufacturer, or otherwise does not necessarily constitute or imply its endorsement or recommendation by the EERC. 


\section{TABLE OF CONTENTS}

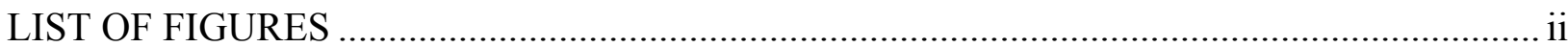

LIST OF TABLES ........................................................................................................... ii

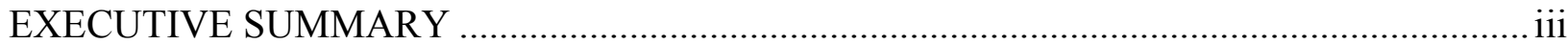

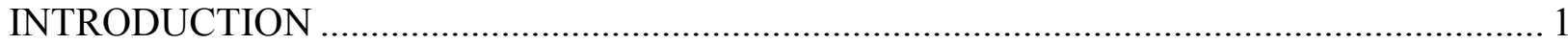

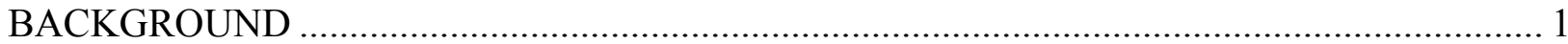

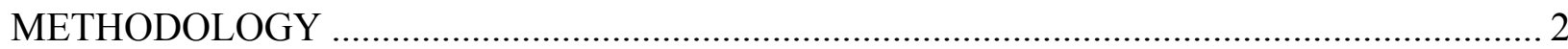

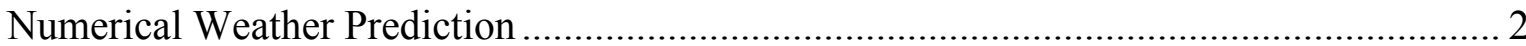

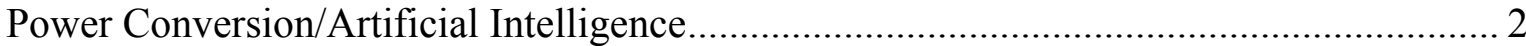

Ensembling/Minimum Variance Estimation.................................................................... 3

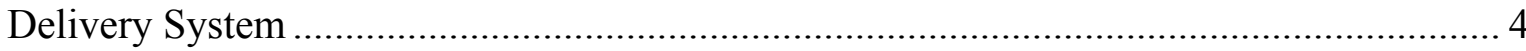

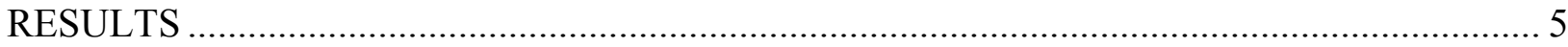

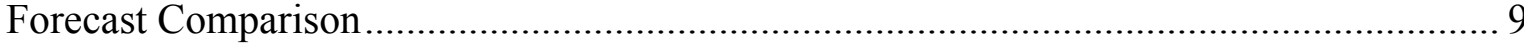

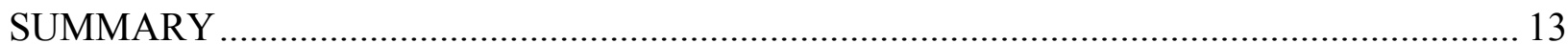

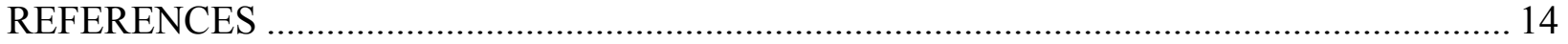




\section{LIST OF FIGURES}

1 Graphical illustration of the trend in WEFS forecast errors with increasing lead times...... 7

2 Time series of hourly energy production for the subject wind farm based on six cycles

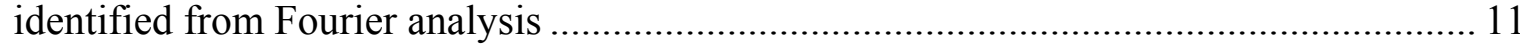

3 Climatology of energy production for the subject wind farm .................................... 11

4 A comparison of mean absolute errors between WEFS forecasts, climatology of production, and a static production forecast equal to $41 \%$ of the wind farm's

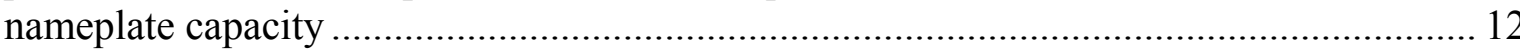

\section{LIST OF TABLES}

1 Mean Absolute Error of Power Production Forecasts from WEFS over the Period $12 / 8 / 2006$ to $3 / 21 / 2007$ 6

2 Forecast Error as a Percentage of Capacity Wind Farm .......................................... 7

3 Short-Term Forecasts with Errors Exceeding 50\% of the Capacity of the Wind Farm........ 8

4 Mean Absolute Errors as a Percentage of Wind Energy Capacity for WEFS and the Current Utility X Forecasting System in Place 


\section{TASK 3 - WIND ENERGY-FORECASTING SYSTEM (WEFS)}

\section{EXECUTIVE SUMMARY}

The Energy \& Environmental Research Center (EERC) and Meridian Environmental Technology, Inc. (Meridian), developed and demonstrated the efficacy of a WEFS for use in scheduling energy output from wind farms for a regional electrical generation and transmission utility (Utility X). The original proposal stated that WEFS would consist of three components: 1) a numerical weather prediction model(s), 2) a wind energy output model, 3) and a graphical user interface. The final design actually melded the first two components together, and the third component was changed from a Web-based graphical user interface to an e-mail-based interface.

WEFS uses ensemble modeling to produce meteorological forecast data. Artificial intelligence software ingests these forecasts along with historical data on wind farm performance and historical weather data to predict energy output. WEFS was developed and tested for a Subject wind farm within Utility X's control area. The Subject wind farm consisted of twentyseven 1.5-MW wind turbines spread out over 10 square miles.

WEFS is able to outperform climatology and the average capacity factor for the wind farm over the first 108 hours, or 4.5 days, of the forecast. The system performs the best during the first 36 hours of the forecast, with an average mean absolute error (MAE) of $17 \%$ of the wind farm's capacity (i.e., 40.5 MW). MAEs increased with longer lead times to 31\% at Forecast Hour 168. Maximum errors increased with time and ranged from $-42 \%(+47 \%)$ to $-87 \%(+92 \%)$. Inaccuracy in the weather forecasts account for a large portion of the errors. However, wind farm power production can be inconsistent with the wind resource at the time and contribute to the size of the forecast error.

The WEFS was compared to the forecast system in place at Utility X. As of the spring of 2006, Utility X received wind forecasts from a reputable industry leader in weather forecasting. These weather forecasts are converted into energy forecasts using technical information about the wind turbines. WEFS and Utility X forecasts were scaled by installed capacities. Results indicate that Utility X's systemwide forecasts performed slightly better than WEFS's forecasts for the subject wind farm. 


\section{TASK 3 - WIND ENERGY-FORECASTING SYSTEM (WEFS)}

\section{INTRODUCTION}

If energy generation can be reliably and accurately forecast, the owner/operators of wind turbines will be able to better estimate and schedule their future power production an hour, a day or, possibly, farther into the future. This, in turn, will add to the value of wind energy and may increase its ability to better compete in the electrical generation market.

\section{BACKGROUND}

Prior to the development of the WEFS, discussions were held with a regional electrical generation and transmission utility (Utility $\mathrm{X}$ ) to learn about its scheduling requirements for power output from wind farms as well as what data we could obtain from its wind farms. The following information was garnered from these discussions:

- WEFS would be designed and demonstrated for a single wind farm located in the northern Great Plains, from which Utility X would be the electrical offtaker.

- Near-real-time wind speed, wind direction, and temperature data for the wind farm are not made available to Utility $\mathrm{X}$ by the wind farm operator.

- Near-real-time power output data are available from the wind farm via an ION SCADA system, and these data could be made available to the Energy \& Environmental Research Center (EERC) and Meridian Environmental Technology, Inc. (Meridian).

- Every weekday, Utility X provides an hourly power output schedule for the next 7 days.

- A graphical user interface was not a desirable feature to Utility X. Instead, Utility X preferred the forecasts be sent to it daily, via e-mail, in a table format.

As a result of these discussions, modifications were made to the initial design of the forecasting system. The biggest change was the use of e-mail instead of a Web-based graphical user interface for delivering the forecasts.

The building and testing of the WEFS occurred between May and November of 2006. The system was put into operation near the end of November, but comparison statistics between forecasts and actual power production excluded data prior to December 8, 2006. The data were excluded because a major ice storm at the end of November severely curtailed production at the wind farm. Both predicted and actual winds were significant over this period, resulting in large errors between the forecasted power production and actual production. Moreover, WEFS was modified during the first week of December which would have a major impact on performance. 


\section{METHODOLOGY}

WEFS builds upon the concepts of ensemble modeling and minimum variance estimation and uses artificial intelligence (AI) to convert meteorological forecast data into power output predictions. Ensemble modeling is a term used loosely to describe a process involving the blending of data from numerous numerical weather prediction (NWP) models to arrive at both a consensus forecast as well as an estimation of the amount of uncertainty in that consensus forecast. The theory of minimum variance estimation is used to combine the forecasts from the NWP ensemble members in a manner that mathematically guarantees a lower consensus error variance than any one of the individual NWP forecasts can provide individually. AI, in the form of neural networks, is applied within WEFS to draw direct relationships between NWP model variables and power output or other observations from an existing wind power facility or measurement facility. A more detailed description of concepts and tools applied in WEFS is provided in the following sections.

\section{Numerical Weather Prediction}

The key predictive data feed into WEFS is provided by NWP models. Meridian receives real-time NWP output from the National Oceanic and Atmospheric Administration (NOAA) Environmental Modeling Center (EMC) as well as the Meteorological Services of Canada (MSC) Canadian Meteorological Centre (CMC). In addition, Meridian maintains real-time feeds to vast global observation resources and utilizes these data in the operation of "mesoscale" NWP models in-house. Mesoscale weather prediction models specialize in forecasting weather with more local detail than the models operated at government centers and can be useful in characterizing how the weather may vary over small distances.

WEFS can be configured to monitor Meridian's database ingest processes for data from any or all of these NWP models and automatically trigger immediate processing of data from any of these models upon arrival. This processing includes extraction of atmospheric profile data for the location of a wind farm from the gridded NWP data, the calculation of derived parameters from the profile data (e.g., parameters such as expected wind gust speeds), and the time interpolation of that profile into a common framework time of the WEFS system. This arrival of a new atmospheric profile from any single NWP model for a given time and location into WEFS triggers all subsequent processing in the system (i.e., the subsequent power conversion and ensembling processes are data-driven). The WEFS forecast for different forecast hours, therefore, updates asynchronously and at frequencies that depend upon how often data arrive into WEFS for its associated lead time.

\section{Power Conversion/Artificial Intelligence}

A cumbersome aspect of the traditional mode of wind energy forecasting can be the conversion of meteorological forecast data into a forecast of power output. In this traditional setting, an extremely high-resolution model is used to simulate the interaction of atmospheric flows with highly detailed local orography and the power facility's own turbines, yielding a turbine-by-turbine wind forecast that can be run through power curves to arrive at whole-facility energy output forecasts. While this concept has considerable scientific merit, the computational 
resources required to perform the power conversion in this manner limits the practicality of applying such a process in concert with the also-valuable concept of ensemble modeling (as it would require repetition of this power conversion process for each member of the NWP model ensemble). The philosophy behind WEFS is that the uncertainties in the meteorological forecast data coming out of NWP models are a more significant detriment to the predictability of wind energy output than the uncertainties associated with subtle nuances in the power conversion from one situation to the next - especially at lead times in excess of a few hours. As such, WEFS employs a less computationally expensive technique for performing the power conversion and, instead, focuses the use of computational resources on the generation of an ensemble of NWP inputs to the WEFS system.

The use of a less computationally expensive method of performing the power conversion should not be misconstrued as equating to a less accurate method of performing this conversion. Given adequate observational data, AI techniques can quickly learn how each individual wind power facility responds to various weather situations. In order to eliminate a step in the process (which would introduce errors), WEFS uses neural networks trained by back-propagation techniques to draw nonlinear relationships between raw and derived variables available in each NWP model forecast and the corresponding whole-facility power output. Multiple neural networks can be applied for a given model, each using a different network structure as well as a different set of predictors drawn out of the NWP model data. However, these predictors are not, in general, required or expected to be turbine-level, readily observable parameters. They are merely predictors that describe any one of a number of aspects of the simulated lower atmosphere in the NWP model that might be expected to have some predictable relationship to the wind power facility energy output. As such, WEFS does not normally create a turbine-level meteorological forecast. The relationships between NWP model parameters and wind power facility output are drawn directly by AI techniques, and the creation of the meteorological forecast is not generally separable from the creation of the power forecast. This is somewhat unusual in the industry.

A recent enhancement to WEFS has been the inclusion of a persistence forecast input. This input is generated by examining the recent hours of wind farm power output in light of similar patterns of power output over the preceding months. Using AI techniques, WEFS makes a projection of the power output going forward based upon similarities of the current power output profile to behavior of the wind farm after similar situations in the past. The resultant persistence forecast, which adds value primarily in lead time ranges of a few hours, is treated identically to the NWP-based input forecasts by the ensembling/minimum variance estimation step of the WEFS processing system (discussed next).

\section{Ensembling/Minimum Variance Estimation}

As discussed above, at time frames in excess of a few hours, Meridian's philosophy in developing WEFS was that uncertainties in the NWP model forecasts quickly become the overwhelming limiter of wind power forecast accuracy. For example, correctly timing the extrema in power output is of critical importance in administering the use of wind energy

resources. Reliance upon a single NWP model forecast leaves the user of the resultant wind power forecast highly susceptible to timing errors in that model's forecast. To combat this 
problem, WEFS statistically combines an "ensemble" of NWP model forecasts to arrive at a consensus forecast that exhibits more robust timing predictions and is also theoretically capable of providing an indicator of forecast uncertainty over time. The ensemble members can be made up of any or all of the following: different NWP models, different physical or dynamical schemes within each NWP model, or different lead times for a given NWP model. The broad range of inputs the ensemble provides creates a powerful filter for distinguishing likely events from outliers in an individual NWP forecast model and, potentially, for providing some measure of the relative uncertainty in a power forecast by analyzing the similarity between the forecasts created by each NWP ensemble member. Likewise, the use of an ensemble of NWP forecasts also reduces WEFS susceptibility to the day-in, day-out shortcomings of any one particular model.

In order to produce the ensemble forecast, a methodology for combining the forecasts from each of the NWP ensemble members must be applied. WEFS applies the mathematical theory of minimum variance estimation to construct the consensus forecast from the ensemble members. The general premise behind minimum variance estimation is that the addition of information from each new source of forecast data will improve a consensus forecast so long as those forecasts are unbiased and weighted correctly. In simple terms, following the mathematical theory of minimum variance estimation to combine forecasts from various sources should guarantee that the combined forecast will be more accurate than that from any of the contributing models taken individually. To apply this concept, WEFS routinely updates and maintains records of the recent and historical performance for each NWP model-neural network combination at the wind power facility (as measured against observations from that wind power facility). WEFS likewise tracks the performance of persistence and climatology forecasts at the wind farm. These NWP, persistence, and climatology forecast performance statistics are used by WEFS when calculating the appropriate corrections and weights to apply in the minimum variance estimation step in order to guarantee a statistically superior ensemble forecast. The corrections and weights assigned to each of these forecast sources are, therefore, able to adapt to the recent performance of each ensemble member over time, allowing WEFS to create an ensemble forecast that is statistically tuned to recent performance.

\section{Delivery System}

WEFS forecasts are updated throughout the day as new data arrive from any of the NWP ensemble members or from the wind farm (i.e., current power output to support a persistence component of the forecast). To support Utility X, the current forecast, available as of 6:00 a.m. daily, is delivered to Utility $\mathrm{X}$ via e-mail. The forecasts of power output are arranged into a table, with the columns and rows representing the hours of the day and the dates of the forecast, respectively. Each table contains hourly forecasts for the current day and the following 7 days, a format requested by Utility $\mathrm{X}$.

Power production forecasts provided by Utility $\mathrm{X}$ to their regional transmission operator (RTO) begin at midnight on the third day of the WEFS forecast. Consequently, Utility X currently does not utilize data from Forecast Hours 1 through 42. The 7-day forecast that Utility $\mathrm{X}$ is obligated to provide to the RTO essentially will only incorporate data from WEFS covering the period from Forecast Hour 42 to 210. Unfortunately, the WEFS or any other wind energy- 
forecasting system to date will generally not have greater skill than climatology at forecasting the weather more than 6 or 7 days (144 or 168 hours) into the future.

\section{RESULTS}

Results presented in this study are referenced by forecast hour. Generally, a forecast hour refers to the number of hours following execution of a numerical weather prediction model. For example, Forecast Hour 1 refers to the first hour following its execution. In the case of WEFS, it executes and updates the forecasts any time new data are available. The forecast product sent to Utility $\mathrm{X}$ at 6:00 a.m. every morning represents the output from the latest execution of WEFS, but the execution could have occurred an hour or more in the past. In order to avoid confusion, Forecast Hour 1 will refer to the first hour after the forecast table has been sent to Utility X or from 6:00 to 7:00 a.m. Forecast Hour 24 will refer to the 5:00 to 6:00 a.m. forecast on the following day, and so on.

Statistics were compiled for WEFS daily forecasts made between December 8, 2006, and March 21, 2007. Forecasts were compared to actual production as recorded by the wind farm's ION SCADA system. The mean absolute errors (MAEs) for several forecast hours are presented in Table 1. MAE values are similar for hourly forecasts in each of the three forecast periods: Hours 1-36, Hours 40-72, and Hours 84-168. The average MAEs over these three periods are approximately $17 \%, 21 \%$, and $28 \%$ of the capacity of the wind farm, respectively. In summary, WEFS performs the best for the first 2 to 3 forecast days.

The forecasts were analyzed for biases and outliers (i.e., poor forecasts). Errors were calculated by determining the difference between actual production and the forecast. The errors were divided by the capacity of the wind farm to provide percentages. Table 2 provides a summary of the percent errors associated with WEFS. For clarification, a negative percentage refers to a forecast that underpredicts the energy production from the wind farm.

The mean and median forecast errors remain near $0 \%$ for the most part (Figure 1). This observation does not mean that the forecast made 168 hours into the future is as accurate as the forecast made an hour into the future. Instead, it signifies that the forecasts are mostly balanced between over- and underpredictions, which indicates that the biases are small and likely not an issue. On the other hand, minimum and maximum errors increase with lead time, which does indicate a deterioration of forecast accuracy with lead time.

Maximum forecast errors of $\pm 40 \%$ and greater are observed at all forecast hours. These large errors were not anticipated at short lead times. Table 3 lists times when the MAE exceeded $50 \%$ for Forecast Hours 1, 2, 4, 8, and 12. In addition to actual and forecast generation, the table provides data on the hourly averaged mean wind speeds and expected range of mean generation. The hourly averaged wind speeds were obtained from reports provided by the wind farm owner to Utility X. A distribution table was created from observed wind speeds and actual wind farm production. Production average and standard deviation were calculated at each wind speed. These statistics were used to calculate a $99 \%$ confidence interval for mean generation based on a standard normal distribution about a given wind speed. 


\begin{tabular}{|c|c|c|}
\hline \multirow[b]{2}{*}{ Forecast Hour } & \multicolumn{2}{|c|}{ Mean Absolute Error } \\
\hline & $\mathrm{kWh}$ & $\%$ of Capacity \\
\hline 1 & 6558 & 16.2 \\
\hline 2 & 6768 & 16.7 \\
\hline 4 & 6822 & 16.8 \\
\hline 8 & 6743 & 16.6 \\
\hline 12 & 6539 & 16.1 \\
\hline 16 & 6948 & 17.2 \\
\hline 20 & 6669 & 16.5 \\
\hline 24 & 7028 & 17.4 \\
\hline 28 & 7406 & 18.3 \\
\hline 32 & 7139 & 17.6 \\
\hline 36 & 6864 & 16.9 \\
\hline 40 & 8063 & 19.9 \\
\hline 44 & 7533 & 18.6 \\
\hline 48 & 8354 & 20.6 \\
\hline 60 & 8583 & 21.2 \\
\hline 72 & 9437 & 23.3 \\
\hline 84 & 10,639 & 26.3 \\
\hline 96 & 10,886 & 26.9 \\
\hline 108 & 10,808 & 26.7 \\
\hline 120 & 12,000 & 29.6 \\
\hline 132 & 10,966 & 27.1 \\
\hline 144 & 11,260 & 27.8 \\
\hline 156 & 11,751 & 29.0 \\
\hline 168 & 12,562 & 31.0 \\
\hline
\end{tabular}

WEFS forecasts for all events listed in Table 3 fall outside of the estimated production ranges, but so do the actual production values. Hence, the large errors are the result of both WEFS and anomalous production. A closer analysis shows that production data for 4 of the 11 hours were further from the estimated production range than the forecasts. In these cases, the wind farm should have generated significantly more energy based on the hourly averaged wind speeds. In other words, perfect knowledge of the winds does not eliminate error in the forecast because factors associated with the operation of the wind farm affect energy production.

An attempt was made to quantify forecast errors associated with wind farm operations. Wind speed observations from a local wind-monitoring tower are used to represent local wind conditions. The wind-monitoring tower is located 3.8 miles northeast from the center of the wind farm. Time frames analyzed are April 1, 2004 - September 30, 2004, and April 1, 2005 - August 13, 2005. 
Table 2. Forecast Error as a Percentage of Wind Farm Capacity (40.5 MW)*

\begin{tabular}{lcccc}
\hline Forecast Hour & Mean Error, $\%$ & Median Error, $\%$ & \multicolumn{2}{c}{ Max Errors, $\%$} \\
\hline 1 & 1.8 & 1.4 & -42 & 51 \\
2 & 0.7 & 0.7 & -44 & 51 \\
4 & 0.8 & 3.8 & -51 & 62 \\
8 & 4.3 & 4.6 & -56 & 66 \\
12 & -0.6 & -2.7 & -52 & 64 \\
16 & -2.9 & -1.7 & -56 & 53 \\
20 & -0.4 & -0.6 & -47 & 50 \\
24 & -0.8 & -2.5 & -57 & 47 \\
28 & 0.6 & 3.3 & -53 & 49 \\
32 & 5.1 & 6.0 & -43 & 51 \\
36 & 0.7 & -0.4 & -56 & 64 \\
40 & 1.4 & 0.5 & -60 & 57 \\
44 & 2.7 & 0.1 & -50 & 63 \\
48 & 1.3 & 0.2 & -56 & 58 \\
60 & 0.1 & 1.2 & -63 & 61 \\
72 & 2.8 & 0.6 & -55 & 80 \\
84 & 0.2 & -1.2 & -85 & 87 \\
96 & 4.9 & -81 & 87 \\
108 & 2.5 & -1.6 & -60 & 80 \\
120 & 0.6 & 4.1 & -61 & 86 \\
132 & 2.9 & -3.7 & -60 & 66 \\
144 & -3.5 & 0.8 & -84 & 90 \\
156 & -1.7 & -2.0 & -87 & 92 \\
168 & -2.3 & 6.0 & -72 & 86 \\
\hline & 1.5 & & & \\
\hline
\end{tabular}

* Statistics cover the period of 12/7/2006 to 3/21/2007.

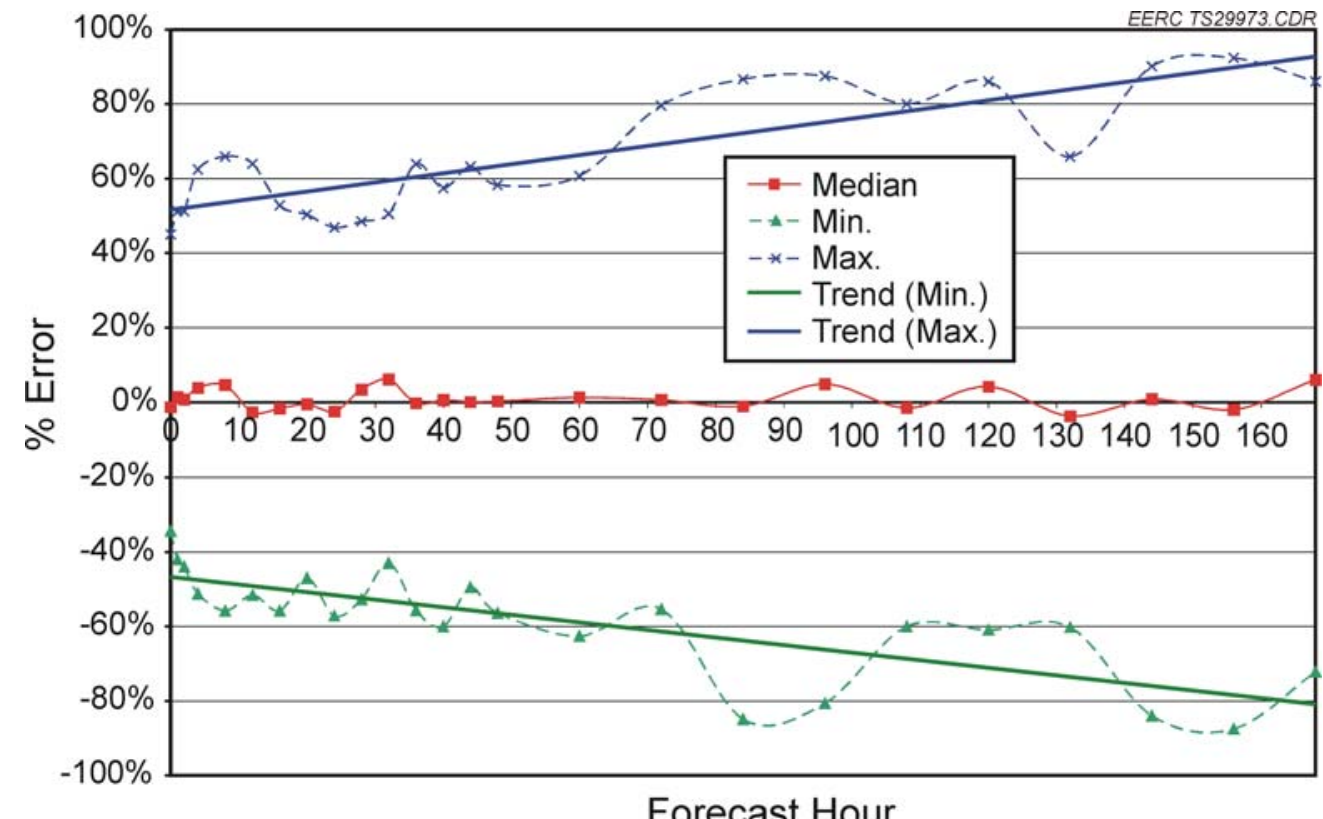

Figure 1. Graphical illustration of the trend in WEFS forecast errors with increasing lead times. 
Table 3. Short-Term Forecasts with Errors Exceeding $50 \%$ of the Capacity of the Wind Farm*

\begin{tabular}{|c|c|c|c|c|c|c|}
\hline $\begin{array}{l}\text { Forecast } \\
\text { Hour }\end{array}$ & $\begin{array}{l}\text { Date and End } \\
\text { Time, } \\
\text { CST }\end{array}$ & $\begin{array}{c}\text { Actual } \\
\text { Production, } \\
\text { kWh }\end{array}$ & $\begin{array}{c}\text { Forecast } \\
\text { Production, } \\
\text { kWh }\end{array}$ & $\begin{array}{c}\text { Error, } \\
\% \text { of capacity }\end{array}$ & $\begin{array}{l}\text { Hourly Averaged } \\
\text { Wind Speed, } \\
\text { meters per second }\end{array}$ & $\begin{array}{l}\text { Est. Production } \\
\text { Range, } \\
\text { kWh }\end{array}$ \\
\hline 1 & $12 / 15 / 20067: 00$ & 983 & 21,700 & $-51 \%$ & 6.6 & $5300-8200$ \\
\hline 2 & $2 / 25 / 20078: 00$ & 0 & 20,300 & $-51 \%$ & 9.5 & $15,000-19,600$ \\
\hline 4 & $1 / 5 / 200710: 00$ & 32,255 & 11,500 & $51 \%$ & 11.4 & $23,500-27,700$ \\
\hline 4 & $2 / 25 / 200710: 00$ & 0 & 24,900 & $-62 \%$ & 9.3 & $14,800-19,400$ \\
\hline 8 & $12 / 9 / 200614: 00$ & 520 & 23,500 & $-57 \%$ & 5.1 & $1900-3800$ \\
\hline 8 & $12 / 12 / 200614: 00$ & 418 & 21,200 & $-52 \%$ & 4.9 & $1900-4200$ \\
\hline 8 & $2 / 25 / 200714: 00$ & 0 & 26,500 & $-66 \%$ & 8.2 & $10,200-13,500$ \\
\hline 8 & $3 / 1 / 200714: 00$ & 31,597 & 9000 & $56 \%$ & 11.8 & $24,800-30,000$ \\
\hline 12 & $12 / 12 / 200618: 00$ & 1718 & 27,500 & $-64 \%$ & 5.5 & $2800-5100$ \\
\hline 12 & $12 / 15 / 200618: 00$ & 7493 & 33,400 & $-64 \%$ & 11.7 & $23,300-27,600$ \\
\hline 12 & 2/28/2007 18:00 & 20,620 & 0 & $52 \%$ & 6.8 & $5600-8700$ \\
\hline
\end{tabular}

* Wind farm production data are associated with hourly averaged wind speed data provided by wind farm operators. A distribution of production values is obtained for wind speeds at every tenth of a meter per second. The estimated production range represents a $99 \%$ confidence interval (based on standard normal distribution statistics) for the mean energy production at a given wind speed. The estimated production range is used to qualify whether the error is due to a poor forecast, an anomalous value of actual production, or both. 
Hourly averaged wind speed data collected at 10,42, and 51 meters were used to calculate the wind speed at 65 meters, which is the hub height of the wind turbines. The Power Law, a common technique used by meteorologists over uniform, nonforested regions, was used to extrapolate wind speeds to hub height. In order to minimize errors associated with poor wind speed measurements, data collected during the winter months were removed in order to eliminate those data that may have been affected by icing conditions.

An official power curve for the GE $1.5 \mathrm{~s}$ wind turbine was used to compute energy generation. The wind farm consists of 27 GE 1.5s wind turbines; hence, the estimated energy production from a single turbine is multiplied by 27 to approximate total production. The calculated energy production is compared to the actual energy production data from the wind farm. The number of wind turbines was adjusted to minimize error between actual and computed energy production. The procedure determined that 25 represented the optimal number of turbines to use for the energy calculation. Typically, one or two turbines are offline for any number of reasons; hence, an argument can be made that 25 represents an average number of turbines in operation at any one time.

Correlation coefficients were calculated between estimated energy production from wind speed data and actual energy production data sets. Estimated to actual energy production had a 0.89 correlation coefficient. The correlation coefficient squared equals 0.79 , which indicates that $79 \%$ of the variability in the wind farm's energy production can be accounted for by wind speed. In short, wind farm operation likely accounts for $20 \%-30 \%$ of the variability in energy production.

The subject wind farm consists of 27 turbines. As mentioned previously, typically one or two turbines are offline at any one time. WEFS attempts to account for this reduction in production capability via its pattern recognition algorithms when analyzing historical production data. However, WEFS cannot predict abrupt changes in production associated with turbine shutdowns or when turbines will be taken offline or when performance of the wind farm changes abruptly (e.g., icing conditions).

The MAE for estimates of energy production from the aforementioned wind speed data is $9.8 \%$ of the capacity of the wind farm. To allow for a margin of error, the MAE associated with the operation of the wind farm is likely between $5 \%$ and $10 \%$. In comparison to WEFS, the average MAE for Forecast Hours 1 through 36 is approximately 17\%, or roughly twice as large. However, the spread of errors is similar between the two methods. As a percentage of wind energy capacity, errors (i.e., actual minus forecast) varied between $-92.5 \%$ and $86.3 \%$. In summary, the wind farm's operation contributes to forecasting errors. At times, this contribution is significant, as described by the larger spread in errors.

\section{Forecast Comparison}

WEFS forecasts were compared to Utility $\mathrm{X}$ current wind energy forecasts, the wind farm's climatology for energy production, and the average hourly production from December 8 , 2006, to March 21, 2007. The average hourly production for the wind farm over this time frame 
is $16,665 \mathrm{kWh}$, or $41 \%$ of the nameplate capacity of the wind farm. For simplicity, this forecast methodology will be referred to as the $41 \%$ capacity method.

Climatology was determined from the past history of production for the subject wind farm. Hourly production data utilized for climatology covered the period from November 1, 2003, to April 30, 2006. Hence, each hour of the year had at least two production values. Data for each hour were averaged together, but these averages hardly constitute a long-term average. A fast Fourier analysis was applied to the averages to identify trends in the data, with the objective of identifying long-term trends.

Fourier analysis, a type of harmonic analysis, is a mathematical tool used for analyzing periodic functions by decomposing such a function into a weighted sum of much simpler sinusoidal component functions, and a fast Fourier analysis refers to a specific algorithm for performing the Fourier analysis. The analysis determined six significant cycles in the data. These cycles are listed below according to significance, and they are labeled by the length of their periodicity:

1. Semiannual $(1 / 2$ year $)$

2. Annual

3. Weekly

4. Semimonthly (2 weeks)

5. Daily

6. Monthly

The six cycles were combined together to provide a single equation to be used to generate a climatology of hourly energy production values for the wind farm. Figure 2 illustrates the data calculated from this equation.

The time series shown in Figure 2 is highly variable for climatology. Based on further analysis, the decision was made to remove the weekly, semimonthly, and monthly cycles from the time series because these cycles are prone to timing issues associated with synoptic patterns (i.e., poor predictability). The biannual, annual, and daily cycles were kept because of their strong correlation to solar insolation (i.e., quantity of solar energy received at the Earth's surface). In general, variations in solar insolation are associated with the Earth's rotation and orbit around the sun, which are very regular and predictable cycles. Figure 3 illustrates the calculated climatology of energy production to be used for this study.

The total variance explained by the annual, semiannual, and daily cycles is only about $5 \%$. Even with the inclusion of the other three cycles, the total variance explained is less than $9 \%$. Consequently, climatology is a poor predictor of energy production. However, climatology will represent the basis for the determination of forecast skill.

Mean absolute errors were computed between actual production and forecasted production from WEFS, 41\% capacity method, and climatology. The evaluation period begins December 8 , 2006, and ends March 21, 2007. Climatology and 41\% capacity method both share similar MAEs. The errors bounce in synchronicity between $27 \%$ and $31 \%$ of the wind farm's capacity 


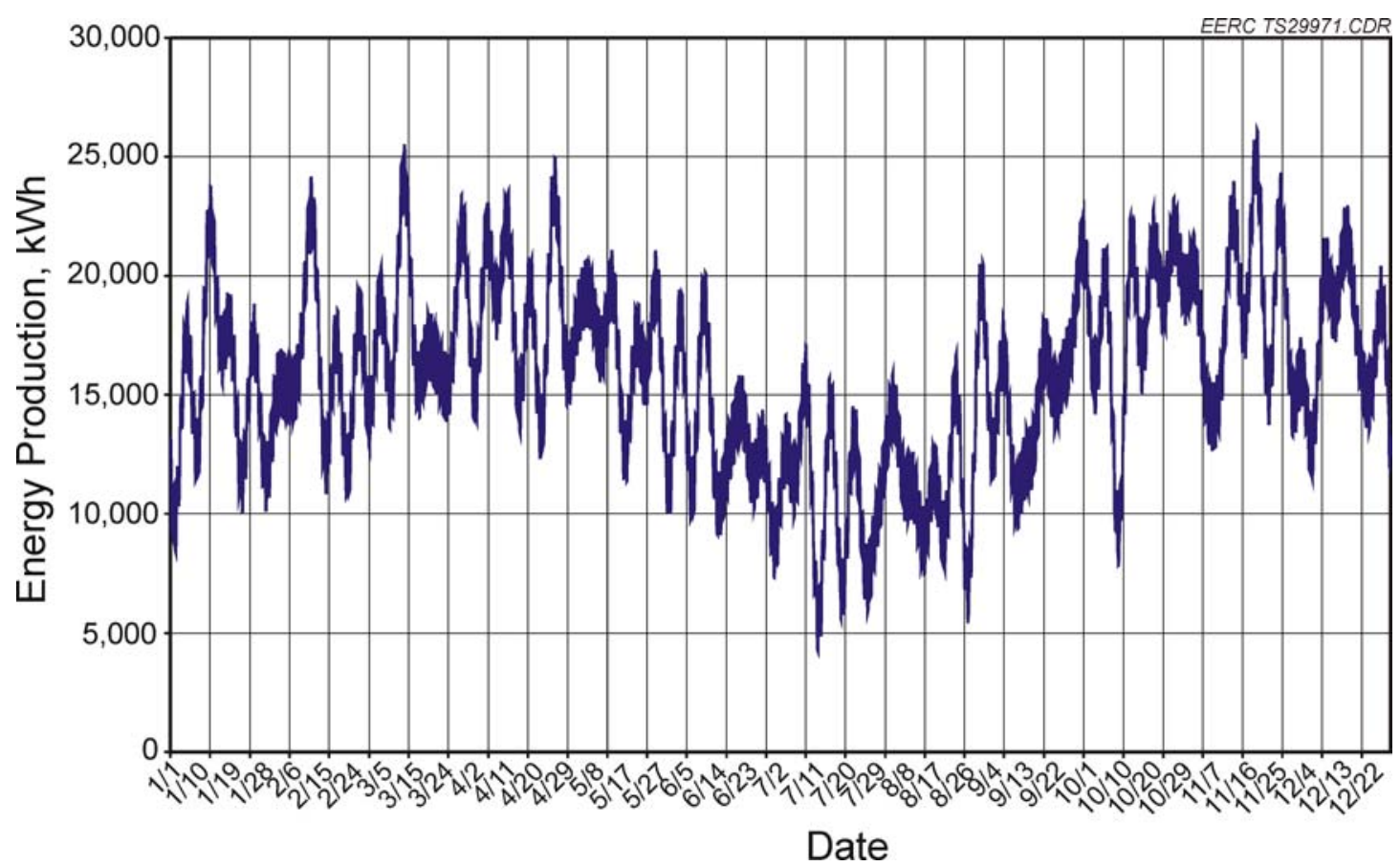

Figure 2. Time series of hourly energy production for the subject wind farm based on six cycles identified from Fourier analysis.

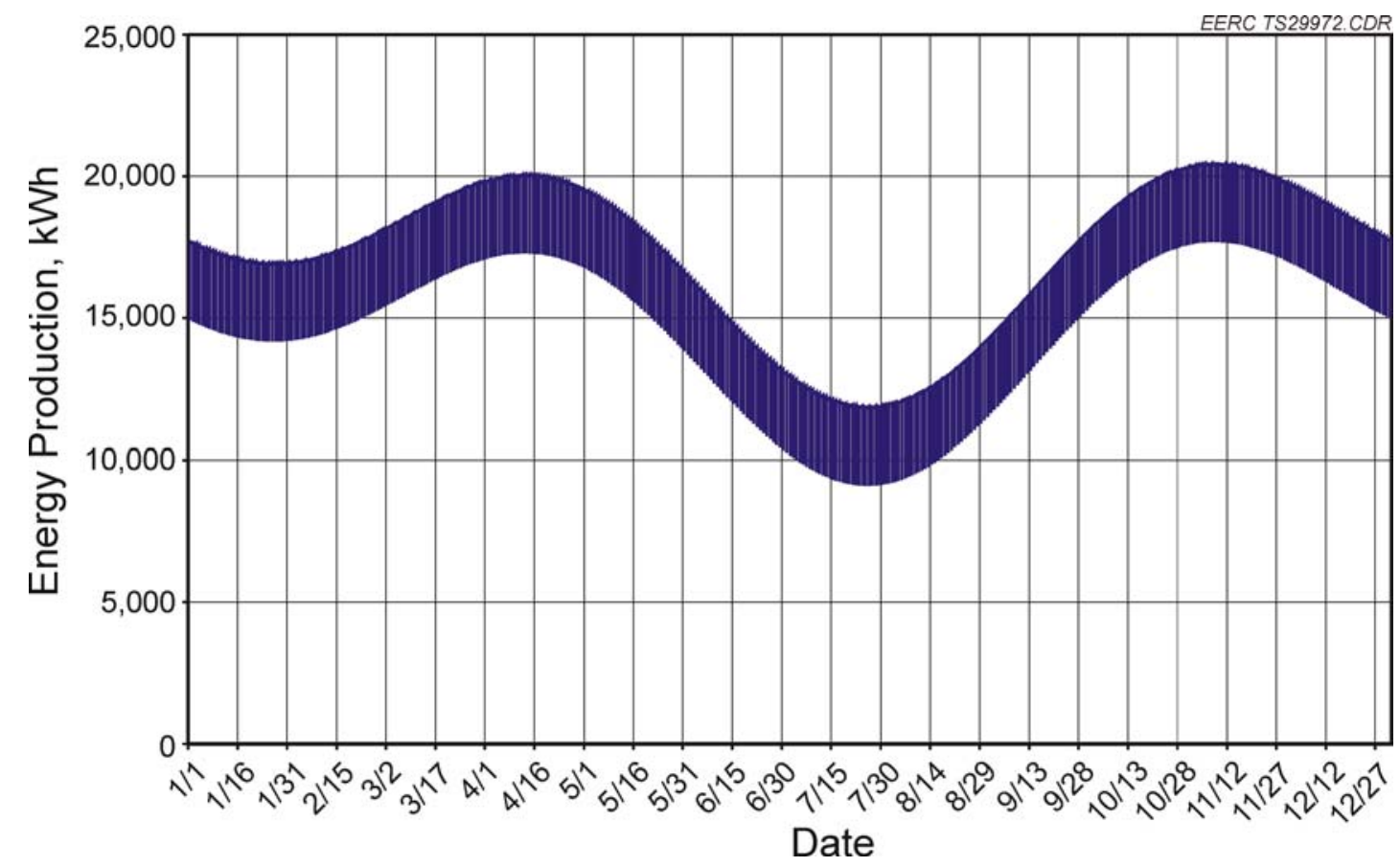

Figure 3. Climatology of energy production for the subject wind farm. The data set represents the combination of annual, semiannual, and daily cycles identified by a Fourier analysis of hourly production data. 
for the hourly forecasts out to 7 days (Figure 4). The correlation between climatology and the $41 \%$ capacity method was unexpected and cannot be explained at this time.

The MAEs for WEFS plotted in Figure 4 are also listed in Table 1. The figure clearly illustrates the similarity in MAE between Forecast Hour 1 and 36, with an average of 17\%. The errors increase gradually over the remaining period (Forecast Hour 40 through 168). From Forecast Hour 108 to 168, WEFS has similar MAEs to climatology and the 41\% capacity method. It should be noted that, based partially upon these results, climatology was added as a predictor to the WEFS forecasts in late March 2007 (i.e., it is treated similarly to AI-transformed information coming from NWP forecast models).

The third source for comparison is Utility $\mathrm{X}$ forecasts. Currently, Utility $\mathrm{X}$ uses staff to empirically determine energy forecasts from weather-forecasts and wind turbine power curves. The weather forecasts were provided by an internationally recognized weather-forecasting company. Utility X considers the energy forecasts to be confidential, so comparisons were performed at their end. Unfortunately, Utility X only archives the combined energy forecasts for all of their wind energy assets. Thus the WEFS forecast was compared to the combined energy forecast for all of Utility X's wind farms.

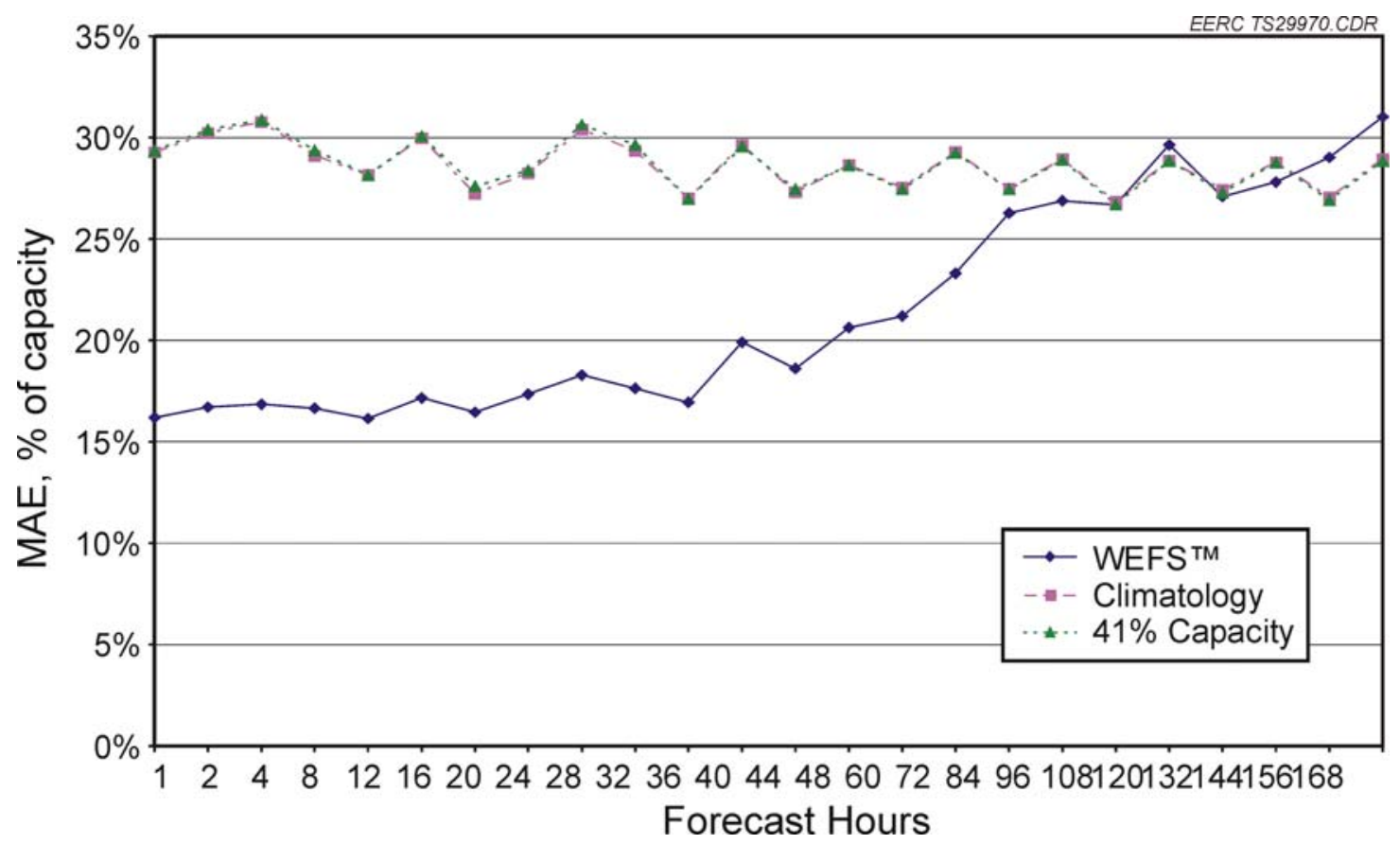

Figure 4. A comparison of mean absolute errors between WEFS forecasts, climatology of production, and a static production forecast equal to $41 \%$ of the wind farm's nameplate capacity. 
Utility X selected the months of January and March 2007 for their comparison study. The data set for March ends on the 21st because the 21 st was when analysis activities began.

The monthly averaged MAEs for January and March are listed in Table 4. As a percentage, the forecast errors are similar, but all values indicate that Utility $\mathrm{X}$ forecasts perform better than WEFS. However, the comparison is misleading as the combined forecasts for the individual wind farms/turbines that make up the Utility $\mathrm{X}$ wind energy portfolio should perform better than for any one individual wind farm because unresolvable "noise" (in either the wind or wind farm operation) will tend to cancel out as more facilities are placed into a combined portfolio.

The 2006 Minnesota Wind Integration Study Report verified this assertion with its finding that the MAE for energy production forecasts was reduced significantly with the aggregation of forecasts from two or more sites. The study explained that production forecasts from multiple sites tend to offset each other as a composite forecast will likely overforecast at some locations and underforecast at others. Hence, forecasts for the aggregate of several locations will be more accurate than any individual location.

\section{SUMMARY}

The WEFS is an artificial intelligence software that utilizes atmospheric data from numerical weather models and wind farm energy production statistics to discern patterns in energy generation. These identified patterns are used to predict future generation for a wind farm. WEFS was designed and tested for a single wind farm consisting of 27 wind turbines located in the northern Great Plains. It has been operational since late November 2006. Forecasts between December 2006 and March 2007 were evaluated for accuracy.

WEFS performed the best during the first 36 hours of the forecast. The MAE over this time frame varied between $16.1 \%$ and $18.3 \%$ of the wind farm's production capacity $(40.5 \mathrm{MW})$, with an average of $16.9 \%$. MAEs increased significantly after 36 hours, reaching $31 \%$ at Forecast Hour 168 (i.e., at the longest lead time). Weather forecasts account for a large portion of the errors. However, times exist when production from the subject wind farm was much less than the expected production based on recorded wind speeds.

Table 4. Mean Absolute Errors as a Percentage of Wind Energy Capacity for WEFS and the Current Utility $X$ Forecasting System in Place

\begin{tabular}{lllll}
\hline & $\begin{array}{l}\text { January } 2007 \\
\text { WEFS, }\end{array}$ & $\begin{array}{l}\text { Utility X, } \\
\text { \% of 40.5 MW }\end{array}$ & $\begin{array}{l}\text { March 2007 } \\
\text { \%EFS, } 137 \mathrm{MW}\end{array}$ & $\begin{array}{l}\text { \% of 40.5 MW } \\
\text { \% of } 13 \text { of 137 MW }\end{array}$ \\
\hline Day Ahead & 17.7 & 17.0 & 19.3 & 17.4 \\
2-Day Ahead & 23.0 & 20.0 & 25.4 & 19.4 \\
\hline
\end{tabular}


A wind energy climatology for the wind farm was generated from Fourier analysis of energy production data. The analysis showed that dozens of different harmonics (i.e., factors) explain the variability in energy production. Three of the strongest harmonics were isolated and combined to create a climatology of energy production for the wind farm. These three harmonics account for approximately $5 \%$ of variability in production.

Capacity factors describing the percentage of potential production were calculated on an hourly basis and averaged over the period. The overall average is approximately $41 \%$. This average capacity was used to back-forecast production (referred to as the $41 \%$ capacity method). The $41 \%$ capacity method and climatology had similar overall MAEs. This result was not expected, so an acceptable explanation is not available. However, both methods were optimized for the location and time frame.

WEFS outperformed both climatology and the $41 \%$ capacity method over the first 108 hours, or 4.5 days, of the forecast. WEFS was also compared to Utility X's forecasts. Utility X's day-ahead forecasts had an average 1.3\% smaller MAE than WEFS. Utility X's 2-day forecasts were an average 4.5\% less than WEFS. However, the comparison of MAEs between Utility $\mathrm{X}$ and WEFS may not be appropriate. For example, WEFS forecasts were made hours before Utility X's forecasts. Additionally, the Utility X forecasts that were analyzed represented its entire wind energy portfolio, and research has shown that an aggregate forecast will statistically outperform a forecast for a single location.

\section{REFERENCES}

WindLogics, Inc., 2006 Minnesota Wind Integration Study; Final Report for the Minnesota Department of Commerce; Nov 30, 2006; p. 135. www.puc.state.mn.us/ docs/windrpt_vol\%202.pdf (accessed 2007). 
APPENDIX C

\section{TASK 4 - ANALYSIS OF THE LONG-TERM ROLE OF HYDROGEN IN THE REGION TOPICAL REPORT}




\title{
TASK 4 - ANALYSIS OF THE LONG-TERM ROLE OF HYDROGEN IN THE REGION
}

\author{
Topical Report
}

Prepared for:

Keith Bennett

U.S. Department of Energy

Golden Field Office

1617 Cole Boulevard

Golden, CO 80401-3393

Agreement No. DE-FG36-05G085037

Prepared by:

Brad G. Stevens Kerryanne M. Leroux

Energy \& Environmental Research Center University of North Dakota 15 North 23rd Street, Stop 9018 Grand Forks, ND 58202-9018 


\section{DISCLAIMERS}

This report was prepared as an account of work sponsored by an agency of the United States Government. Neither the United States Government, nor any agency thereof, nor any of their employees makes any warranty, express or implied, or assumes any legal liability or responsibility for the accuracy, completeness, or usefulness of any information, apparatus, product, or process disclosed or represents that its use would not infringe privately owned rights. Reference herein to any specific commercial product, process, or service by trade name, trademark, manufacturer, or otherwise does not necessarily constitute or imply its endorsement, recommendation, or favoring by the United States Government or any agency thereof. The views and opinions of authors expressed herein do not necessarily state or reflect those of the United States Government or any agency thereof.

\section{ACKNOWLEDGMENTS}

This report was prepared with the support of U.S. Department of Energy (DOE) Cooperative Agreement No. DE-FG36-05G085037. However, any opinions, findings, conclusions, or recommendations expressed herein are those of the authors(s) and do not necessarily reflect the views of DOE.

\section{EERC DISCLAIMER}

LEGAL NOTICE This research report was prepared by the Energy \& Environmental Research Center (EERC), an agency of the University of North Dakota, as an account of work sponsored by DOE. Because of the research nature of the work performed, neither the EERC nor any of its employees makes any warranty, express or implied, or assumes any legal liability or responsibility for the accuracy, completeness, or usefulness of any information, apparatus, product, or process disclosed or represents that its use would not infringe privately owned rights. Reference herein to any specific commercial product, process, or service by trade name, trademark, manufacturer, or otherwise does not necessarily constitute or imply its endorsement or recommendation by the EERC. 


\section{TABLE OF CONTENTS}

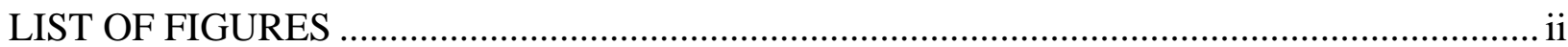

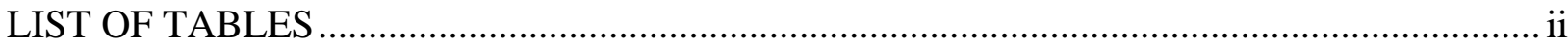

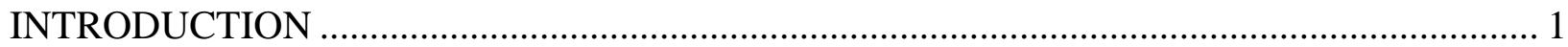

ROLE OF HYDROGEN IN THE GREAT PLAINS ............................................................... 1

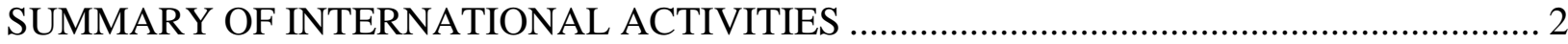

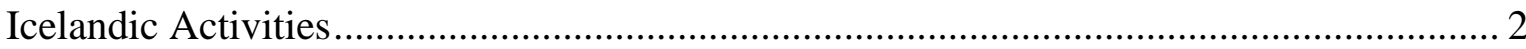

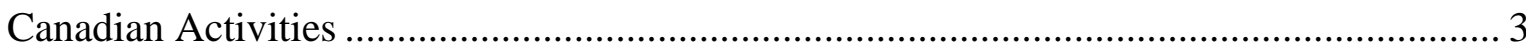

European Union (EU) Activities ............................................................................... 4

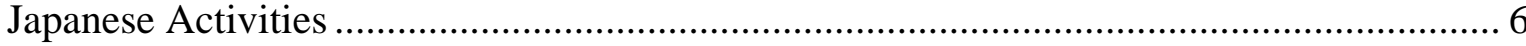

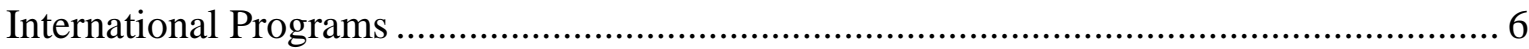

Hydrogen as a Transportation Fuel ............................................................................... 7

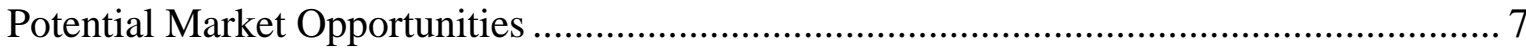

Technical and Economic Barriers ...................................................................................... 9

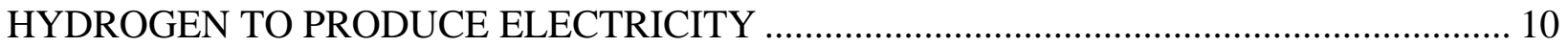

Potential Market Opportunities ……………………….............................................. 12

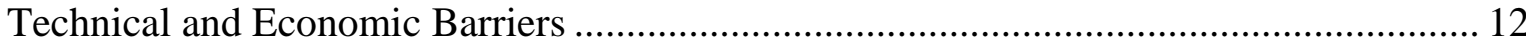

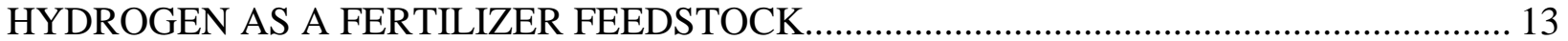

Potential Market Opportunities ……………………………………………………..... 13

Technical and Economic Barriers ................................................................................... 14

ANALYSIS OF HYDROGEN AS A FERTILIZER FEEDSTOCK............................................ 14

Technical Evaluation..................................................................................................... 15

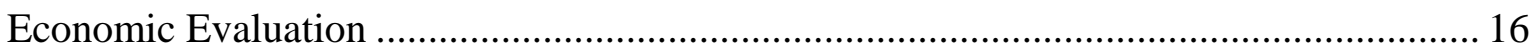

Summary of Hydrogen as a Fertilizer Feedstock ……………..................................... 17

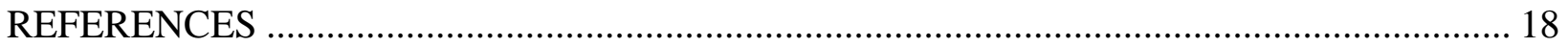




\section{LIST OF FIGURES}

1 Summary of hydrogen generation pathways ........................................................... 2

2 Map for Canada’s Hydrogen Highway ................................................................. 5

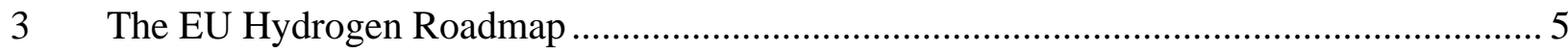

4 The ECTOS-hydrogen station, Shell Hydrogen......................................................... 8

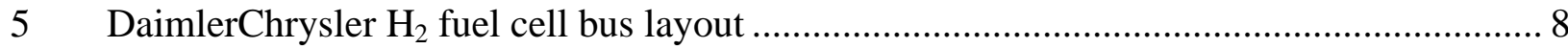

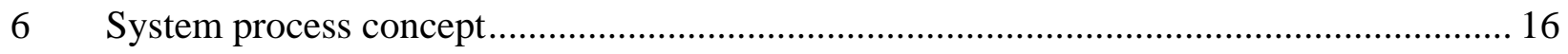

$7 \quad$ Average U.S. farm price for anhydrous ammonia and urea ......................................... 17

\section{LIST OF TABLES}

1 Commercial Hydrogen Vehicle Options and Capabilities .............................................. 9

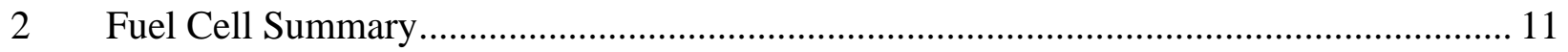




\section{GREAT PLAINS WIND ENERGY TRANSMISSION DEVELOPMENT PROJECT TASK 4 - ANALYSIS OF THE LONG-TERM ROLE OF HYDROGEN IN THE REGION}

\section{INTRODUCTION}

With the increased interest in the production of hydrogen as a critical future energy source, many have viewed hydrogen produced from wind-generated electricity as an attractive option. In addition, many of the hydrogen production-related concepts involve utilization of energy resources without the need for additional electrical transmission.

For this reason, this report provides a summary of end uses for hydrogen in the region and will focus on one end product in particular (fertilizer), including several process options and related economic analyses.

It is important to note that this document was prepared as part of a larger multitask project. During the course of the project, this task (and the resulting report) was performed early in the overall project time line and, therefore, the time-sensitive information included in this report, especially in the "Summary of International Activities" Section, is very dated. Unfortunately, the budget did not allow for an update of the information to be included.

\section{ROLE OF HYDROGEN IN THE GREAT PLAINS}

In this report, the Energy \& Environmental Research Center (EERC) will analyze the role of hydrogen in the region, including an examination of the following:

- Summary of international activities

- Identification of hydrogen uses in the region

- Potential market opportunities

- Technical and economic barriers

As background, hydrogen can be generated by several methods, including primary and secondary pathways. Primary pathways are those in which where the hydrogen is derived directly (steam reforming of natural gas, coal gasification, nuclear, and biomass), and secondary pathways are those where energy, usually in the form of electricity, is applied to split water into oxygen and hydrogen (renewable energy and nuclear). Figure 1 depicts the variety of hydrogen production pathways (1). 


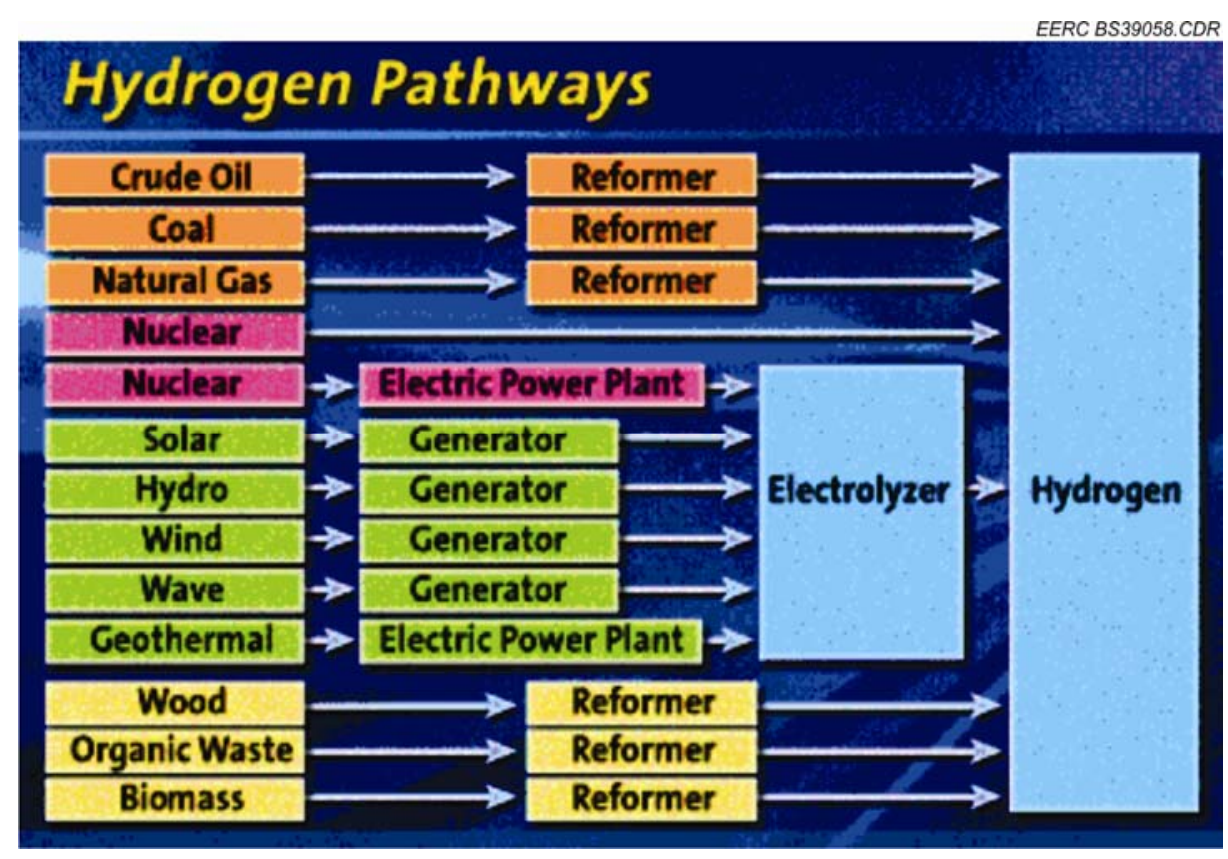

Figure 1. Summary of hydrogen generation pathways.

\section{SUMMARY OF INTERNATIONAL ACTIVITIES}

The development of a hydrogen economy is motivated by various factors, such as environmental benefits; availability of natural resources; and desire for greater energy efficiency, diversification of national energy portfolios, and reductions in fossil fuel imports. Four of the major global players in the promotion of hydrogen utilization as an energy source are Iceland, Canada, the European Union, and Japan. National goals range from extending current demonstration projects to a comprehensive national hydrogen economy by 2050. Both national and international efforts have produced numerous projects and programs for hydrogen production infrastructure, hydrogen utilization, and the commercialization of hydrogen-related technologies.

\section{Icelandic Activities}

Iceland's wealth of natural energy resources and relatively low imports of fossil fuels offers a unique opportunity for implementation of a hydrogen economy. President Olafur Ragnar Grimsson envisions complete conversion of fossil fuel applications to hydrogen by 2050 (2). Execution of this goal focuses mainly on the transition of the transportation industry from conventional technologies to hydrogen fuel cells.

The lack of competition from domestic fossil fuels, low imports of fossil fuels, small population, and abundance of natural domestic energy provide Iceland with a platform for replacement of fossil fuels with hydrogen. With a population of less than 300,000, hydropower and geothermal applications sustain all of Iceland's space-heating and domestic electrical needs 
(3). No domestic fossil fuel industry exists; thus one-third of the country's energy requirements are supplied by imported fossil fuels, mostly for transportation purposes (2).

Major hydrogen projects in Iceland include fuel cell buses, passenger vehicles, and marine vessels. Plans for passenger vehicles and marine vessels have yet to be realized. The initial goal was for every city bus to be hydrogen-powered within a decade, and the first demonstration project for a fuel cell ocean vessel was to be accomplished by 2006, with a complete conversion of the fishing fleet to begin in 2015 (2). For the last 4 years, three hydrogen fuel cell buses have been running as part of the ECTOS (Ecological City TranspOrt System) Program (see International Programs section). The demonstration of fuel cell passenger vehicles was expected to follow the bus demonstration; the hydrogen fueling station constructed for use by the buses could service a dozen cars (4). Unfortunately, high costs for fuel cell vehicles at 4-10 times the prices of conventional automobiles are stretching a hydrogen economy conversion out an additional 10-15 years (3). Challenges to marine vessels are the development of advanced hydrogen storage materials needed for the long duration at sea because of the high volume requirement of gaseous hydrogen (4).

\section{Canadian Activities}

Where the motivation for promoting a hydrogen economy in most countries is driven by concerns over national security or dependence on imported fossil fuels, Canada's efforts are propelled by environmental issues. A majority of government funding dedicated toward hydrogen fuel cell demonstrations ultimately comes from climate change and global-warming programs. Focus is, therefore, dedicated to the advancement and commercialization of energyefficient and innovative technologies for the reduction of carbon emissions: hydrogen utilization via fuel cells.

The Canadian hydrogen program is generating projects along the spectrum of research and development (R\&D), demonstration, and commercialization (5). Hydrogen R\&D is organized into four program areas: production, storage, utilization (fuel cells), and codes and standards. Canada recently established an installation code for hydrogen; the codes and standards are generally proton exchange membrane (PEM)-focused, with small efforts for solid oxide fuel cells (SOFCs) and alkaline fuel cells. Demonstration efforts include portable, stationary, and mobile (on- and off-road) applications. A Canadian Fuel Cell Commercialization Roadmap was generated to identify the challenges for commercialization as well as the actions required by industry and government to overcome those challenges (6).

Few goals for hydrogen utilization exist within Natural Resources Canada (NRC) as focus is related to the industry and market for hydrogen and fuel cells (5). Deployment this year in mobile, stationary back-up power, and forklifts is expected to promote commercialization of hydrogen technologies (7). The Canadian Transportation Fuel Cell Alliance (CTFCA) program has a general goal of presenting refueling demonstration projects by 2008 (8). Canadian Prime Minister Paul Martin announced in April 2004 the goal to build a Hydrogen Highway ${ }^{\mathrm{TM}}$ for the 2010 Winter Olympics (9). 
Projects under the CTFCA include the Hydrogen Village and the Vancouver Fuel Cell Vehicle Program (VFCVP). The Hydrogen Village is a commercial-scale demonstration and deployment of hydrogen and fuel cell technologies within a defined regional area for use by an acting community. Projects implemented include a switching station, exhibition place refueling station and utility vehicles, hydrogen fuel cell-powered forklifts, a hydrogen vehicle and dispense station, and development of SOFCs (8). VFCVP is a 5-year fleet demonstration program of five fuel cell vehicles (7). A hydrogen fueling station is to be built in British Columbia to service VFCVP, as well as the Hydrogen Highway (8).

The Hydrogen Highway (Figure 2) is the demonstration and deployment of a hydrogen fueling infrastructure. The project demonstrates transportation, stationary, portable, and micropower applications, including the operational, economic, environmental, and social feasibility of a hydrogen fueling infrastructure while testing various hydrogen production and delivery options (8). The demonstration sites currently planned are the Vancouver International Airport, Powertech Labs in Surrey, the NRC's Institute for Fuel Cell Innovation, downtown Vancouver, Sacré-Davey in north Vancouver, the Whistler Village, and the University of Victoria/British Columbia Transit (8).

\section{European Union (EU) Activities}

The EU has been diligently creating a hydrogen economy to reduce its dependence on energy importation. Currently, half the total energy consumed is imported as coal, oil, and gas, which could increase to 70\% within the next 20-30 years (10). Three-quarters of the petroleum requirement in the EU is supplied by the Middle East, the remainder provided by sources in the North Sea (9). Several goals have been set by the EU to promote hydrogen production, utilization, and fuel cell commercialization.

Specific EU goals support the growth of the hydrogen industry through the coming decades. Early markets such as specialty vehicles and portable applications are to be established by 2010, and commercialization of fuel cell vehicles and stationary applications are expected by 2015 (11). The EU plans to replace $20 \%$ of traditional automotive fuels with alternatives, which include hydrogen, by 2020 (12). Implementation of mass market transportation applications is also planned at this time. The most aggressive goal is found in the EU Road Map (Figure 3), which promotes meeting new energy demands with hydrogen, projecting $32 \%$ of cars to be hydrogen-powered by 2040 (9).

To facilitate these goals, the European Hydrogen and Fuel Cell Technology Platform (HFP) was created to coordinate national research activities in hydrogen production and utilization technologies. An example activity occurring within HFP is the modification of an existing natural gas pipeline for hydrogen distribution (9). The implementation plan is expected at the end of 2006, followed by a program of industrial research and technological development and demonstration on hydrogen and fuel cells in late 2007 (12). 


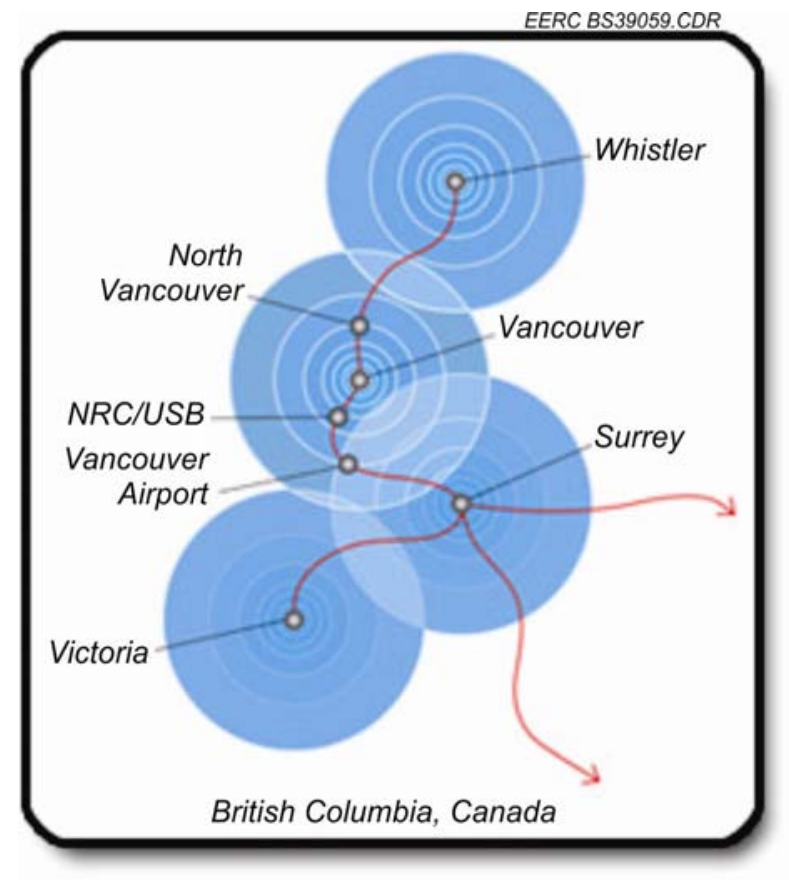

Figure 2. Map for Canada’s Hydrogen Highway (9).

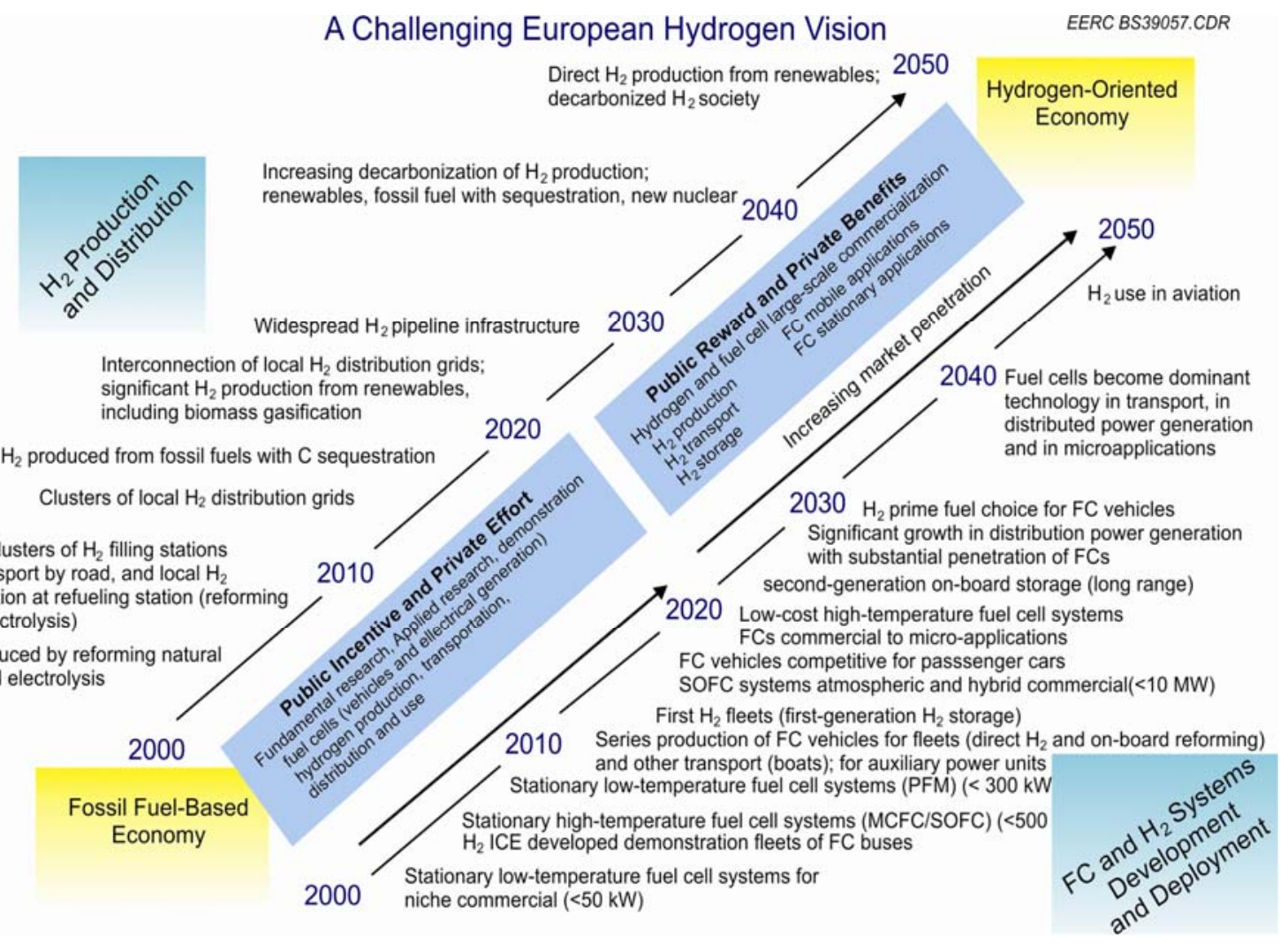

Figure 3. The EU Hydrogen Roadmap (9). 


\section{Japanese Activities}

Diversification of the energy industry and reduction of dependence on imports is the motivational force for implementation of a hydrogen economy in Japan. Any petroleum products must be imported as there are no domestic petroleum resources available. Therefore, the Japanese Ministry of Economy, Trade and Industry (METI) has made a goal of full commercialization of fuel cells and infrastructure by 2020 (9).

The METI goal will be achieved in three phases: demonstration, fuel cell introduction, and hydrogen propagation (9). The demonstration phase will establish codes and standards as well as develop and demonstrate fuel cell technology. Fuel cells will continue to be introduced to the energy and transportation sector for a goal of 50,000 fuel cell vehicles and 2.1-GW stationary fuel cell applications by 2010. The propagation of hydrogen technology will then commence to reach the goal of 5 million fuel cell vehicles, 4000 hydrogen filling stations, and $10 \mathrm{GW}$ of stationary fuel cell cogeneration facilities by 2020 .

The New Hydrogen Project and the Japan Hydrogen and Fuel Cell Demonstration Project (JHFC) have been implemented to assist Japan in achieving the METI goal. The New Hydrogen Project develops hydrogen technologies, focusing on fuel cells and hydrogen production and storage. The focus of this program is to facilitate and promote fuel cell commercialization. JHFC is a combined effort of public and private organizations to demonstrate various hydrogen production and reforming technologies, constructing 12 refueling stations to study various technology options, and to demonstrate the performance of 60 fuel cell vehicles (13). A variety of resources investigated for hydrogen production include but are not limited to natural gas, methanol, naphtha, gasoline, water, coke oven gas, and liquid propane gas. Technologies studied are reforming and electrolysis to produce either a liquid or gaseous product.

JHFC demonstrations to date include fuel cell buses, fueling stations, and stationary applications. The Oume Hydrogen Station, the first mobile hydrogen fueling station, includes hydrogen generation, purification, compression, and storage and is trailer-mounted to supply hydrogen to vehicles in remote areas from fixed stations (14). By the fall of 2005, the 12 hydrogen refueling stations had been installed and eight fuel cell buses were operational. Fuel cell buses at the Central Japan International Airport (Centrair) began full-scale operation in July 2006 with construction of the Centrair Hydrogen Station fueling facility (15). The stationary fuel cell demonstration program has installed $4001-\mathrm{kW}$ residential proton exchange fuel cells (PEFCs) and plans are in place to install another 700-1000 units this year (16).

\section{International Programs}

There are also several international efforts promoting the hydrogen economy on a global level. For example, the International Partnership for the Hydrogen Economy (IPHE) and the ECTOS and CUTE (Clean Urban Transport for Europe) Programs involve a wide variety of nations working together to achieve this common goal.

Established in 2003, IPHE is a collaborative effort for further progression of the global hydrogen economy. Partners include Australia, Brazil, Canada, China, European Commission, 
France, Germany, Iceland, India, Italy, Japan, Republic of Korea, New Zealand, Norway, Russian Federation, United Kingdom, and the United States (13). The purpose of this international institution is to provide a forum for policies, codes and standards, and education efforts as well as a mechanism for hydrogen technology development and implementation.

The ECTOS/CUTE projects are EU initiatives to test three fuel cell buses for 4 years in Reykjavik, Iceland, and in each of nine European cities (Amsterdam, Barcelona, Hamburg, London, Luxembourg, Madrid, Oporto, Stockholm, and Stuttgart). Beijing and Perth also support three fuel cell buses each. Both programs will be continued for another year in only seven of the initially tested cities: Amsterdam, Barcelona, Hamburg, London, Luxembourg, Madrid, and Reykjavik (17). The project was designed to identify viable drive concepts for city buses and production technologies and processes for hydrogen production and distribution. An example of the precommercial hydrogen filling station and a layout of the fuel cell bus are given in Figures 4 and 5, respectively. The additional year of testing will allow necessary improvements to be made to the overall systems, including design, construction and operation of safe hydrogen supply chains and refueling stations, efficient production and use of hydrogen, and infrastructure optimization (12).

\section{Hydrogen as a Transportation Fuel}

The use of hydrogen as a vehicle fuel is a new and evolving industry. It is broadly viewed by many as the most logical near-term target for displacing traditional petroleum fuels.

These vehicles all use hydrogen as fuel to propel the vehicle but can be separated into two main types: those that use fuel cell technology and those that use internal combustion engine technology. In addition, some vehicles operate on hydrogen only while others operate on a multifuel platform (hydrogen-gasoline, hydrogen-diesel, or hydrogen-compressed natural gas [CNG]). A detailed list of commercial hydrogen-powered vehicle (or equipment) options and platforms is shown in Table 1 (19).

\section{Potential Market Opportunities}

Most of the motivation to replace petroleum gasoline with hydrogen, as in the case of renewable fuels (ethanol and biodiesel), is the desire to reduce dependence on foreign sources of petroleum and be more self-sufficient.

Much opportunity exists for hydrogen across the transportation sector. Focusing solely on gasoline transportation fuel, the market potential is approximately 9.1 million barrels per day, or 139 billion gallons per year (2005 U.S. gasoline consumption) (20). 


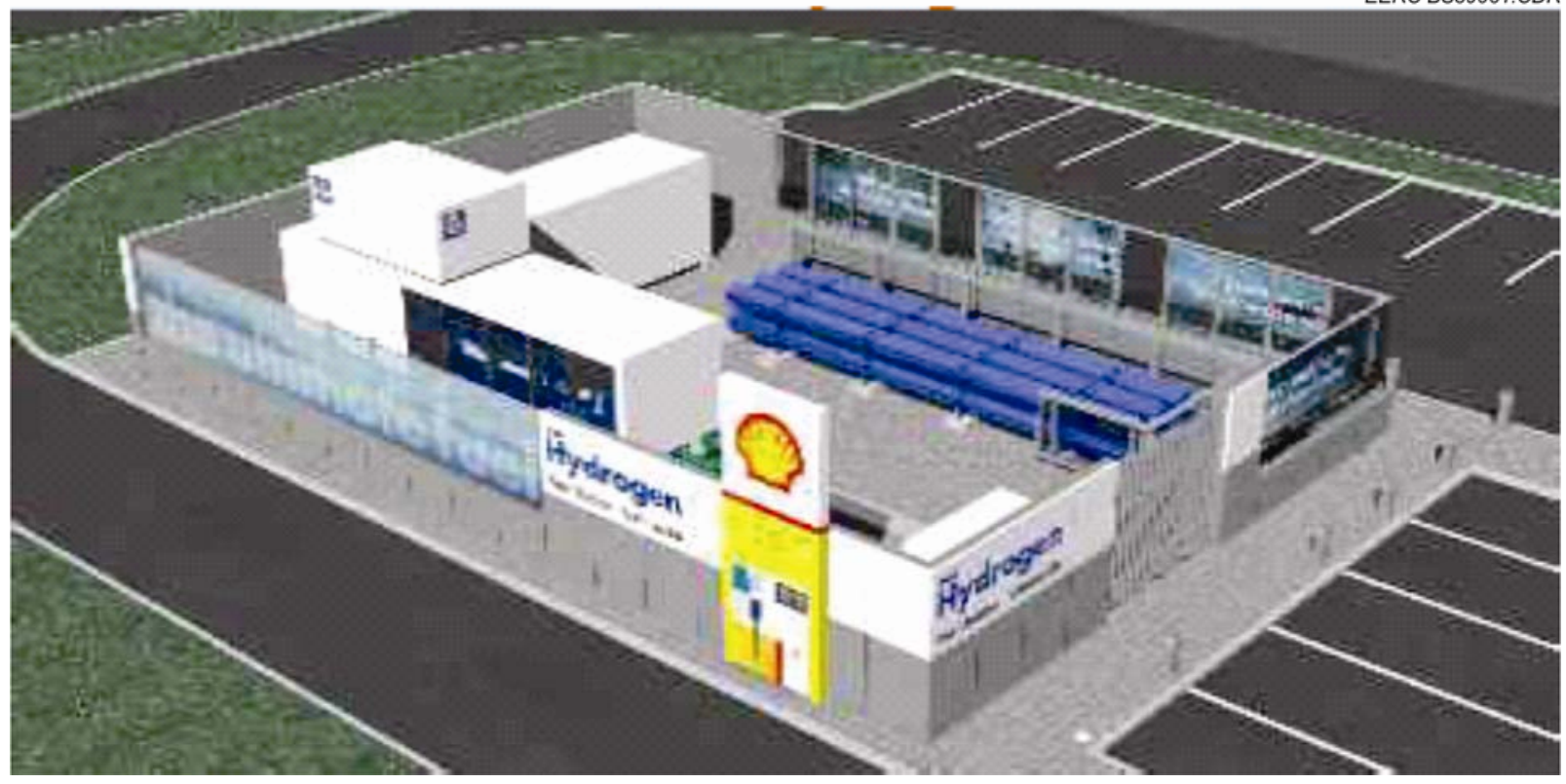

Figure 4. The ECTOS-hydrogen station, Shell Hydrogen (18).

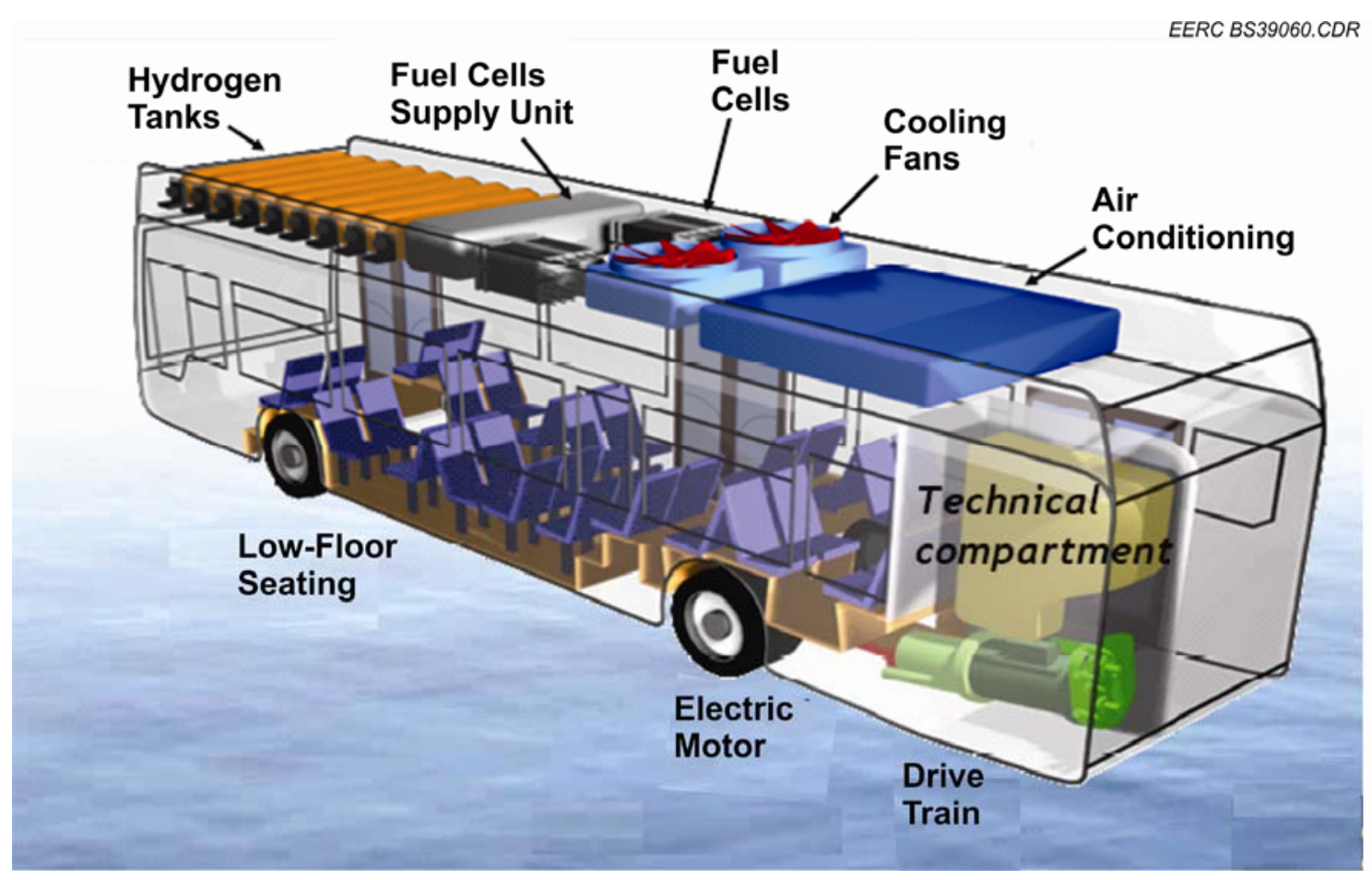

Figure 5. DaimlerChrysler $\mathrm{H}_{2}$ fuel cell bus layout (18). 
Table 1. Commercial Hydrogen Vehicle Options and Capabilities

\begin{tabular}{|c|c|c|}
\hline Power Plant Type & Fuel Capability & Vehicle Platforms \\
\hline Fuel Cell & Hydrogen only & $\begin{array}{l}\text { All lift trucks and } \\
\text { smaller vehicles more } \\
\text { available than buses or } \\
\text { cars. }\end{array}$ \\
\hline $\begin{array}{l}\text { Hybrid Hydrogen- } \\
\text { Internal Combustion } \\
\text { Engine (HH-ICE) }\end{array}$ & $\begin{array}{l}\text { Hydrogen only and } \\
\text { electric }\end{array}$ & Buses \\
\hline $\begin{array}{l}\text { Hydrogen-Internal } \\
\text { Combustion Engine } \\
\text { (H-ICE) }\end{array}$ & Hydrogen only & $\begin{array}{l}\text { Shuttle buses, trucks, } \\
\text { cars }\end{array}$ \\
\hline Multifuel, CNG & $\begin{array}{c}\text { CNG, hydrogen } \\
\text { compressed natural gas } \\
\text { (HCNG) (hythane), switchover } \\
\text { to gasoline capability }\end{array}$ & Shuttle vans, trucks \\
\hline Multifuel, gasoline & $\begin{array}{c}\text { Hydrogen with } \\
\text { switchover to gasoline } \\
\text { capability }\end{array}$ & GM 2500 truck \\
\hline Multifuel, diesel & $\begin{array}{c}\text { Hydrogen with } \\
\text { switchover to diesel capability }\end{array}$ & GM 2500 truck \\
\hline Multifuel, CNG-gasoline & $\begin{array}{l}\text { Hydrogen with } \\
\text { switchover to CNG or gasoline } \\
\text { capability }\end{array}$ & $\begin{array}{l}\text { Chevrolet Express } \\
\text { van }\end{array}$ \\
\hline Conversion Kits & $\begin{array}{l}\text { CNG-gasoline automatic } \\
\text { switching }\end{array}$ & $\begin{array}{l}\text { GM and Ford } \\
\text { engines }\end{array}$ \\
\hline
\end{tabular}

\section{Technical and Economic Barriers}

Key technical, or more appropriately logistical, barriers associated with the use of hydrogen in the transportation sector derive from the question-What happens first, development of production and delivery infrastructure or development of market demand?-in more common terms, the age old "chicken and egg" problem. The ability to store hydrogen also poses a significant obstacle.

Other significant barriers for use of hydrogen in the transportation sector involve economics and cost-competitiveness, specifically the cost per unit of hydrogen fuel. Hydrogen must compete with incumbent petroleum fuel (gasoline) to capture market share and, therefore, must at least approach a direct competitiveness with the cost of gasoline.

A small penetration into the gasoline market may be realized by providing a "blended" gasoline product of $95 \%$ gasoline and 5\% hydrogen. It has been reported that this blended gasoline can significantly reduce emissions of nitrous oxide by $30 \%-40 \%$ in vehicle exhaust (21). Additionally, there have been demonstration programs involving blends of up to $15 \%$ by 
volume of hydrogen added to natural gas to create "hythane." In this case, the hydrogen provides up to $5 \%$ of the energy content of the hythane (22).

On July 14, 2005, the U.S. Department of Energy (DOE) released the following statement (23):

In 2005, the Department of Energy developed a new hydrogen cost goal and methodology. The previous hydrogen cost goal of $\$ 1.50 /$ gasoline gallon equivalent (gge, delivered, untaxed, 2001\$, by 2010) was developed in 2002, and was based on hydrogen produced from distributed natural gas reforming. The strategy was that hydrogen should cost no more than gasoline on an equivalent energy basis. Since one kilogram of hydrogen contains approximately the same energy as one gallon of gasoline, the hydrogen cost goal was set at $\$ 1.50 / \mathrm{kg}$ (or $\$ 1.50 / \mathrm{gge}$ ) to be equivalent to the untaxed cost of gasoline.

The new hydrogen cost goal of \$2.00-3.00/gge (delivered, untaxed, 2005\$, by 2015) is independent of the pathway used to produce and deliver hydrogen. In addition, the new methodology accounts for the energy efficiency of the gasoline hybrid vehicle and the fuel cell vehicle on a cost-per-mile basis. The cost goal was derived using the National Academy of Sciences (NAS) fuel-efficiency improvement factors and the Energy Information Administration (EIA) "High A" gasoline price projection for 2015. In the High A case, the U.S. economy is more vulnerable to limited oil supplies from foreign sources due to the increasing world and U.S. oil demand, resulting in higher oil prices. This case is more representative of the economic and energy security environment in which hydrogen must compete.

For 2005, the average retail reformulated gasoline price was $\$ 2.335$ per gallon (24). In comparison, the EERC and the National Renewable Energy Laboratory analysis estimated the cost of hydrogen from electrolysis to be slightly more than $\$ 4.00$ per kilogram under the best circumstances $(19,25)$. Since 1 kilogram of hydrogen has approximately the same Btu content as 1 gallon of gasoline, hydrogen is compared with gasoline on the basis gallon gas equivalent (gge) when the comparison is done in the context of transportation fuel.

\section{HYDROGEN TO PRODUCE ELECTRICITY}

The production of electricity using hydrogen can be accomplished by delivering hydrogen to a fuel cell, internal combustion engine, microturbine, or gas turbine.

Several different fuel cells are commercially available, and each platform has its own positives and negatives. Table 2 summarizes each fuel cell type, their characteristics, and the traditional use of the platform (26).

The use of internal combustion engines to produce electricity involves the same conversions discussed in the vehicle sector section. The internal combustion engine is converted 
Table 2. Fuel Cell Summary

\begin{tabular}{|c|c|c|c|c|}
\hline Fuel Cell Type & Typical Application & Efficiency & Advantages & Disadvantages \\
\hline Alkaline (AFC) & $\begin{array}{ll}\text { - } & \text { Military } \\
\text { - } & \text { Space }\end{array}$ & $60 \%-70 \%$ & - High efficiency & $\begin{array}{l}\text { - Requires removal of } \mathrm{CO}_{2} \\
\text { from fuel }\end{array}$ \\
\hline $\begin{array}{l}\text { Proton Exchange } \\
\text { Membrane } \\
\text { (PEM) }\end{array}$ & $\begin{array}{ll}\text { - } & \text { Back-up power } \\
\text { - } & \text { Portable power } \\
\text { - } & \text { Small distributed } \\
& \text { generation } \\
\text { - } & \text { Transportation }\end{array}$ & $50 \%-60 \%$ & $\begin{array}{l}\text { - Solid electrolyte reduces corrosion } \\
\text { and electrolyte management } \\
\text { problems } \\
\text { - } \quad \text { Low temperature } \\
\text { - } \text { Quick start-up }\end{array}$ & $\begin{array}{l}\text { - } \quad \text { Requires expensive catalysts } \\
\text { - High sensitivity to fuel } \\
\text { impurities } \\
\text { - } \quad \text { Low-temperature waste heat }\end{array}$ \\
\hline SOFC & $\begin{array}{ll}\text { - } & \text { Auxiliary power } \\
\text { - } & \text { Electric utility } \\
\text { - } & \text { Large distributed } \\
& \text { generation }\end{array}$ & $60 \%$ & $\begin{array}{l}\text { - } \text { High efficiency } \\
\text { - } \quad \text { Fuel flexibility } \\
\text { - } \quad \text { Can use a variety of catalysts } \\
\text { - } \text { Solid electrolyte reduces } \\
\text { electrolyte management problems } \\
\text { - } \quad \text { Suitable for combine heat and } \\
\quad \text { power (CHP) applications }\end{array}$ & $\begin{array}{l}\text { - High temperature enhances } \\
\text { corrosion and breakdown of } \\
\text { cell components } \\
\text { - Slow start-up }\end{array}$ \\
\hline $\begin{array}{l}\text { Molten Carbonate } \\
\text { (MCFC) }\end{array}$ & $\begin{array}{ll}\text { - } & \text { Electric utility } \\
\text { - } & \text { Large distributed } \\
& \text { generation }\end{array}$ & $60 \%$ & $\begin{array}{l}\text { - High efficiency } \\
\text { - } \quad \text { Fuel flexibility } \\
\text { - } \quad \text { Can use a variety of catalysts } \\
\text { - Suitable for CHP }\end{array}$ & $\begin{array}{l}\text { - High temperature speeds } \\
\text { corrosion and breakdown of } \\
\text { cell components } \\
\text { - Complex electrolyte } \\
\text { management } \\
\text { - Slow start-up }\end{array}$ \\
\hline $\begin{array}{l}\text { Phosphoric Acid } \\
\text { (PAFC) }\end{array}$ & - Distributed generation & $36 \%-42 \%$ & $\begin{array}{l}\text { - } \text { High efficiency } \\
\text { - } \quad \text { Increased tolerance to impurities in } \\
\text { hydrogen } \\
\text { - } \quad \text { Suitable for CHP }\end{array}$ & $\begin{array}{l}\text { - } \quad \text { Requires platinum catalysts } \\
\text { - } \quad \text { Low current and power } \\
\text { - } \quad \text { Large size/weight }\end{array}$ \\
\hline
\end{tabular}


to operate, either totally or partially, on hydrogen, and the engine is coupled with an electrical generator to accomplish the conversion.

Microturbines are already available commercially and are currently designed to work on natural gas, not hydrogen. With key modifications, including a catalytic combustor, the microturbine could be converted into a Flex-Microturbine ${ }^{\mathrm{TM}}$, which is much more fuel-flexible and capable of running on a whole range of hydrogen fuel gases with much lower purity than required by fuel cells (27).

Gas turbines, also referred to as combustion turbines, have been used for many years to generate electricity. Traditionally gas turbines utilized more common fuels such as natural gas, but many entities including DOE are pursuing efforts to operate gas turbines on hydrogen-rich syngases derived from coal.

\section{Potential Market Opportunities}

The market for electricity, although large and growing, is highly dispersed and the characteristics of the market vary greatly even within the region. The total retail sales of electricity in the United States in 2005 totaled more than 3,660 gigawatt-hours (28).

The opportunity for hydrogen in the electrical sector is more likely to present itself in the near-term where retail electricity prices are high such as the mid-Atlantic and New England states on the East Coast of the United States and the noncontiguous Pacific states of Hawaii and Alaska.

There may be a long-term potential market opportunity for hydrogen in the electrical sector in the scenario of a carbon-managed world. That is, additional costs would be built into the cost of current electrical generation (fossil derived); therefore, broadening the market for hydrogenderived electricity on a cost-competitive basis.

Opportunity may also exist in areas where hydrogen is already produced as a product of low demand (and low value) or as a by-product, providing additional revenue.

\section{Technical and Economic Barriers}

As with other sectors, the use of hydrogen to produce electricity is primarily limited because of economic barriers not technical barriers. The few technical barriers that exist are different depending on which platform is used to convert the hydrogen to electricity. The technologies that utilize combustion of the fuel face issues related to fuel delivery, fuel compatibility, and system optimization. Technical barriers related to systems that utilize fuel cell technology are somewhat more prevalent and are associated with low system efficiencies.

Economic barriers that exist are similar to the other sector opportunities in that in each sector, hydrogen must displace the market from the incumbent fuel or fuels and, therefore, must compete on a cost basis. Many of the technical barriers mentioned above are as much economic issues as they are technical issues. 
Fuel cell technology probably presents the most challenges, both technical and economic. A typical fuel cell electrical system would consist of hydrogen generation, hydrogen compression and storage, and the fuel cell. The hydrogen can be generated, by a multitude of methods: electrolysis, steam reforming of methane, and coal gasification, to name a few. Each of these contributes different technical and economic implications to overall system. The main barrier with this type of system is related to overall system efficiency. The hydrogen generation step, if renewable energy such as wind energy is used to drive the electrolysis of water, will have an efficiency of $30 \%$ to $40 \%$; the compression and storage operation is likely to be $85 \%$ to $90 \%$ efficient; and, depending on the fuel cell type, the conversion of hydrogen to electricity can be as low as $36 \%$ or as high as $70 \%$ efficient.

\section{HYDROGEN AS A FERTILIZER FEEDSTOCK}

Fertilizers play a crucial role in maximizing the production of the world's food supply. The Fertilizer Institute indicates that without commercial fertilizers, nitrogen (N), phosphorus (P), and potassium (K), the world's food production would be reduced by one-third (29). Of the three main commercially produced fertilizers, nitrogen is arguably the most important and will be the focus of further discussion of fertilizers in this report.

Nitrogen fertilizer is primarily delivered to crops in the form of either anhydrous ammonia $\left(\mathrm{NH}_{3}\right)$ or urea $\left(\mathrm{CO}\left[\mathrm{NH}_{2}\right]_{2}\right)$. Anhydrous ammonia is most commonly produced by combining nitrogen from air and hydrogen from natural gas at very high temperatures $\left(450^{\circ}-500^{\circ} \mathrm{C}\right)$ and pressures (100-300 atmospheres [atm]) in the presence of an iron catalyst. This process in commonly known as the Haber-Bosch process, and the resulting anhydrous ammonia contains $82 \%$ nitrogen and is a gas that is handled as a liquid under pressure, similar to propane.

One of the most common nitrogen fertilizer-derived forms of ammonia is urea, a solid product applied in a granular form and comprising $46 \%$ nitrogen. Urea is produced by combining anhydrous ammonia and carbon dioxide at high pressure.

Since 97\% of all nitrogen fertilizers are derived from anhydrous ammonia (30), a product of natural gas, the cost of these fertilizers is heavily dependent on the price of natural gas. The cost of natural gas represents $70 \%$ to $90 \%$ of the production cost of anhydrous ammonia (31). Manufacturing 1 ton of anhydrous ammonia requires 33,500 cubic feet (33.5 million Btu) of natural gas $(32,33)$.

\section{Potential Market Opportunities}

Given the heavy dependence on natural gas as the source of hydrogen to the nitrogen fertilizer process, one of the most intriguing opportunities for hydrogen in the region involves the utilization of hydrogen derived from alternative sources such as renewable energy. The market potential for nitrogen fertilizers (a product highly dependent on hydrogen) is significant.

The United States is the third largest consumer and producer of nitrogen fertilizer in the world behind China and India and is the largest importer of nitrogen fertilizers (34). U.S. 
nitrogen fertilizer consumption in 2007 was nearly 10 millionmaterial tons for anhydrous ammonia and urea alone (35).

In addition to the abundant renewable resources in the region, there exist tremendous nontraditional natural gas sources in the form of coal and coalbed methane as well as unused byproducts such as wellhead gas in the oil industry that could provide a hydrogen source.

\section{Technical and Economic Barriers}

Technical barriers associated with the use of renewable electricity-generated hydrogen for fertilizer production include implementing a water electrolysis process large enough in scale to accommodate the input demand for ammonia production. Based on stoichiometry, it requires approximately 161 kilograms of hydrogen to produce 1 ton of ammonia fertilizer. To fully satisfy the 2003-2004 ammonia imports of approximately 7 million tons (36) annually would require more than 1.1 billion kilograms of hydrogen, or 3.1 million kilograms daily.

In addition, the technical issues associated with scaling down the high-pressure and hightemperature fertilizer production process (after the introduction of hydrogen) may be significant and will require additional investigation and research.

Economic barriers are related to the cost of producing a hydrogen feedstock for the ammonia process at a price competitive with hydrogen derived from either natural gas or coal gasification. The ability of electrolysis hydrogen to capture market share from natural gasderived hydrogen may not solely be dependent on cost but may also be impacted by issues such as an increased call for utilizing stranded renewable energy resources, pressure to reduce fertilizer imports, or a desire to reduce demand on natural gas as a fertilizer feedstock.

\section{ANALYSIS OF HYDROGEN AS A FERTILIZER FEEDSTOCK}

It has been well documented that the Great Plains states have a tremendous wind resource. The wind resource in North Dakota alone has enough theoretical wind energy potential to provide more than $25 \%$ of the annual electrical demand for the lower 48 states (1210 kWh) (37).

However, wind energy development in much of the region has not reached even a fraction of its potential because of the existence of a constrained electricity transmission grid.

As an alternative to producing electricity, wind turbines could be used to produce hydrogen as a feedstock to the nitrogen fertilizer (primarily ammonia and urea) process. Unlike the hydrogen fuel market, the nitrogen fertilizer market is mature, readily accessible, and growing each year. In addition, the intermittency of wind energy is less important in the production of fertilizer than electricity. The ideas presented here require research and development before a near commercial-scale demonstration could be performed. 


\section{Technical Evaluation}

Prior to 1913, ammonia was obtained mainly from natural sources. Haber and Bosch developed a process in 1913 for catalytically combining hydrogen with molecular nitrogen at very high temperatures $\left(450^{\circ}-500^{\circ} \mathrm{C}\right)$ and pressures $(100-300 \mathrm{~atm})$ on a promoted iron catalyst, resulting in a conversion yield of $10 \%-20 \%$.

The use of wind energy to electrolyze water and provide hydrogen to the anhydrous ammonia production process offers a unique approach to extracting value from wind energy without the need for increased transmission capacity or the need to compensate for the intermittence of wind and a non-natural-gas-based route for fertilizer production, which will become increasingly important to both farmers and fertilizer manufacturers as natural gas prices increase.

In addition, North Dakota and other regions of the northern Great Plains have abundant wind energy, most of which is being utilized to make electricity. Wind-generated electricity is intermittent in nature and tends to be located in sparsely populated areas. This location is a hindrance in the scenario of electrical generation, but in the case of producing fertilizer it is actually an asset because it is in the same location as the product end user. As a possible alternative to natural gas-derived fertilizer, the production of either ammonia or urea using windgenerated electricity to drive the process should be considered.

Incorporating the use of ethanol plant-generated carbon dioxide into the process to produce urea offers an additional benefit of an economically promising method for utilization of pointsource carbon dioxide emissions (especially the relatively clean emissions from ethanol plants).

Figure 6 represents the overall system process concept. Included in Figure 6 are the following:

- Three potential sources of hydrogen for anhydrous ammonia production: coal gasification, steam reforming of natural gas, and wind energy-driven electrolysis of water.

- Two potential sources of carbon dioxide for the production of urea: ethanol plant emissions and coal-fired power plant emissions.

As shown stoichiometrically in Figure 6, 2 moles of water electrolyze into 2 moles of hydrogen. In more practical terms, 2.4 gallons of water results in 1 kilogram, or 421 standard cubic feet, of hydrogen.

In comparison, 1 mole of natural gas and 1 mole of water supplied to the steam-reforming process produce 3 moles of hydrogen. Again, in more conventional terms, that same kilogram of hydrogen requires 140 cubic feet of natural gas (38) and 5 gallons of water (39). 


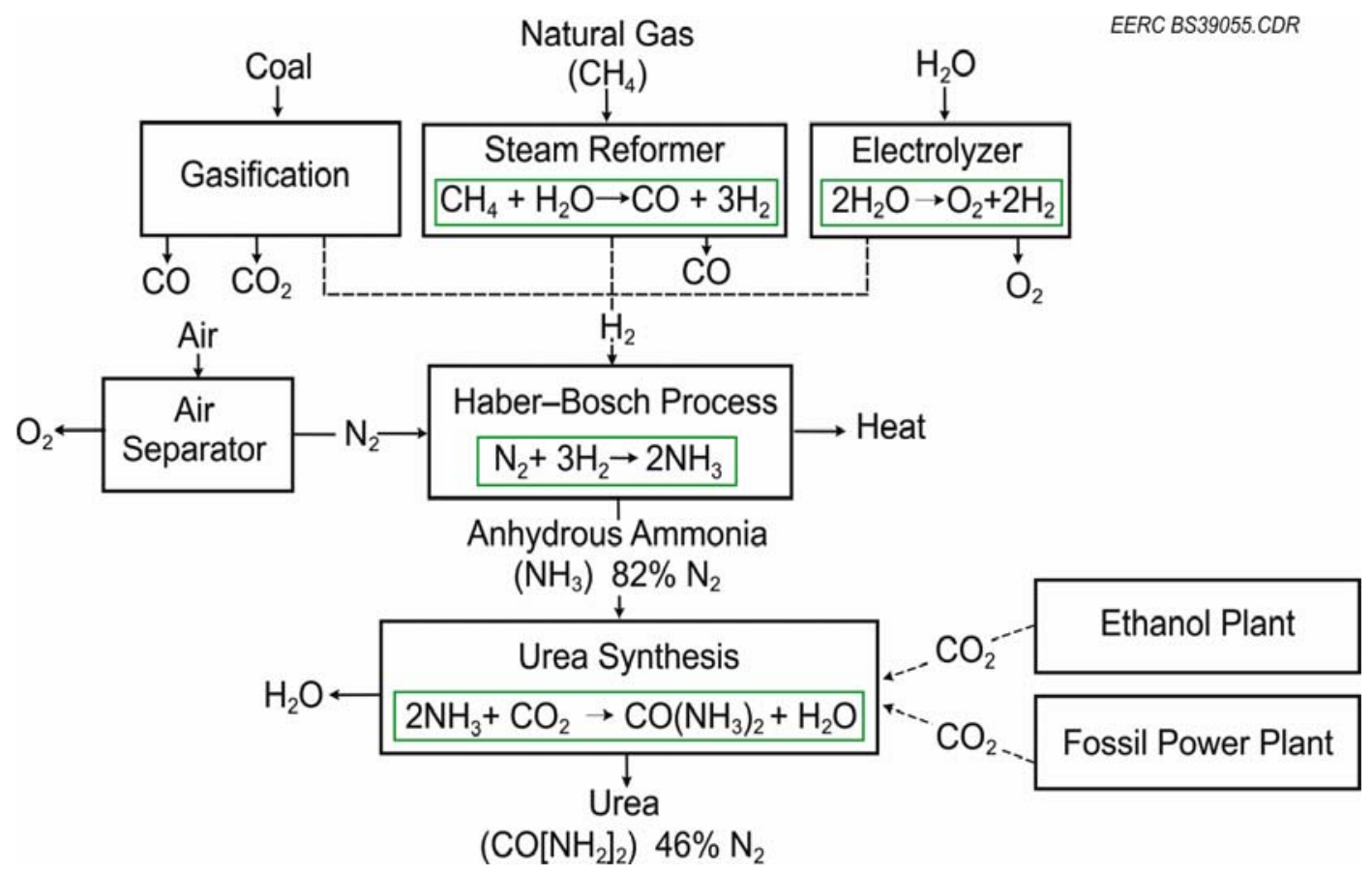

Figure 6. System process concept.

Assuming 1 ton of anhydrous ammonia requires hydrogen input of approximately $161 \mathrm{~kg}$, or 68,000 scf, and using the approximate feedstock input quantities discussed above, the following input requirements can be made:

- Electrolysis: 386 gallons of water

- Steam methane reforming: 22,540 cubic feet of natural gas and 805 gallons of water

In the case of hydrogen generated using electrolysis, technical issues may present themselves (possibly significant issues) with matching the scale of processes between electrolysis and the Haber-Bosch process.

\section{Economic Evaluation}

Hydrogen for the ammonia process is typically supplied from syngas obtained by reforming hydrocarbons (natural gas). Thus the cost of ammonia production is directly tied to the price of natural gas. Natural gas represents between $70 \%$ and $90 \%$ of the cost of anhydrous ammonia production (33). The average natural gas wellhead price for 2005 was \$7.33 per thousand cubic feet (40).

Based on U.S. Department of Agriculture data (41), the U.S. average farm-level price for ammonia jumped in spring 2005 to the historic high level of \$416 per ton and reached \$521 in spring 2006. Similarly, urea prices increased to \$332 and \$362, respectively, in those years. It is important to note that fertilizer delivered for use in the spring is manufactured the previous fall or winter; therefore, pricing is based on the natural gas price during that prior fall or winter (36). 
According to June 2003 testimony to Congress by Robert C. Luizzi, President of CF Industries, Inc., a major fertilizer producer, the U.S. nitrogen fertilizer industry is at serious risk because of high natural gas prices. This was at a time when anhydrous ammonia prices were less than $\$ 400$ per ton.

From 1960 to the mid-1990s, fertilizer prices were relatively stable and nitrogen fertilizer prices were driven primarily by demand. In the mid-1990s, natural gas and, correspondingly, nitrogen fertilizer price volatility changed significantly. This was a result of natural gas industry deregulation in combination with a dramatic reduction in the domestic production capacity and an increase in the percent of imported natural gas (36). Figure 7 shows the average U.S. farm price for anhydrous ammonia and urea from 1960 through 2008 (41).

If nitrogen-based fertilizer products remain at current pricing levels or increase, the economics of distributed production using non-natural gas inputs to make these fertilizer products may be feasible.

\section{Summary of Hydrogen as a Fertilizer Feedstock}

- $\quad$ Nitrogen-derived fertilizer products are a crucial part of the world's food production.

- $\quad$ Anhydrous ammonia is the primary nitrogen-based fertilizer and is traditionally produced with hydrogen from reforming natural gas and nitrogen from air.

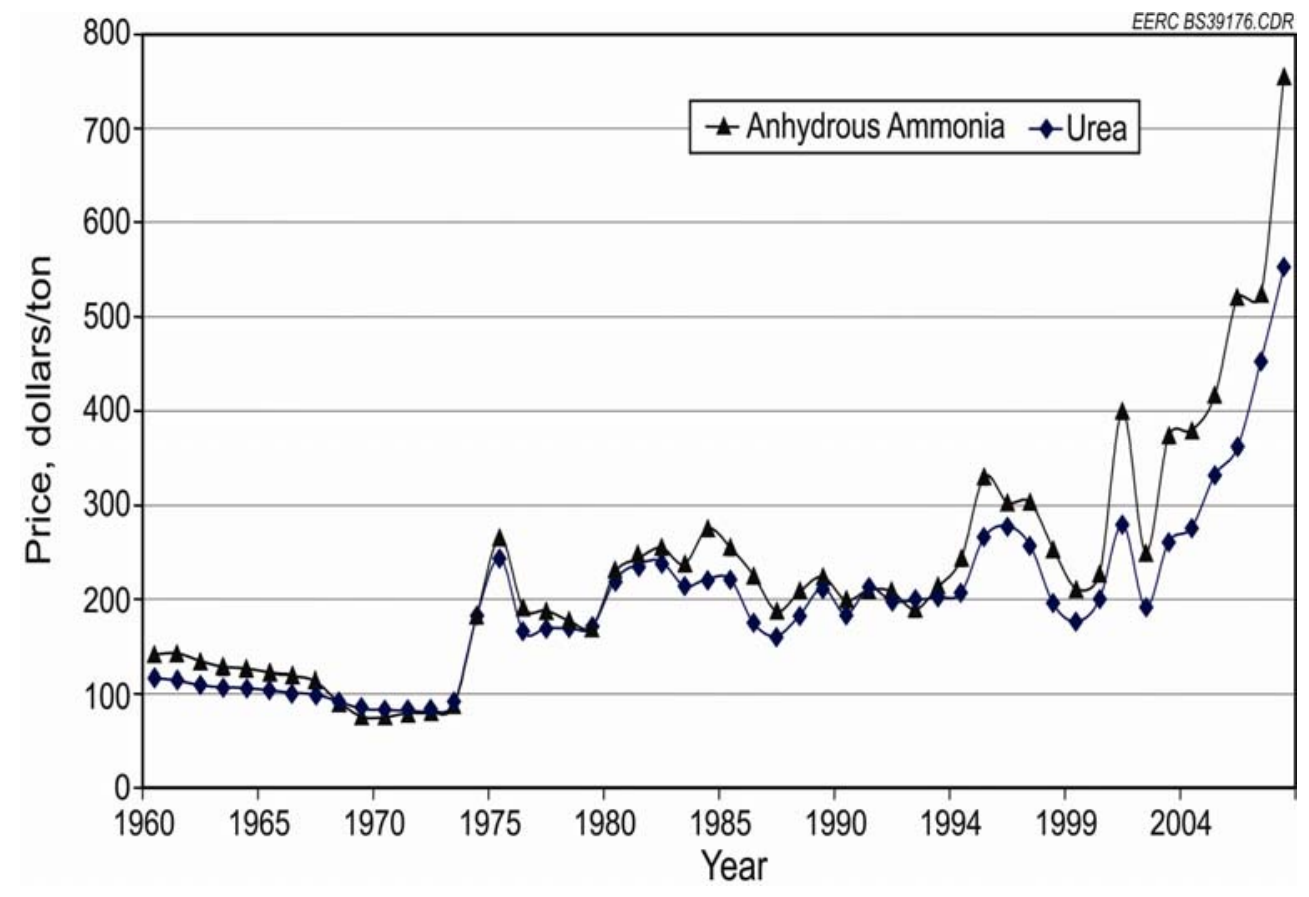

Figure 7. Average U.S. farm price for anhydrous ammonia and urea. 
- The price of natural gas represents as much as $90 \%$ of the anhydrous ammonia price.

- A large product demand exists in the United States, with nearly 10 million material tons of anhydrous ammonia and urea consumed in 2007.

- Technical barriers exist in relation to the scalability of hydrogen feedstock production alternatives such as electrolysis.

- $\quad$ Economic feasibility primarily rests on the ability to construct and operate a plant that produces a nitrogen-based fertilizer product that is price-competitive with natural gasderived fertilizers.

\section{REFERENCES}

1. International Clearinghouse for Hydrogen Commerce Web site. www.hydrogencommerce.com (accessed Nov 2006).

2. Sigfusson, A. Iceland: Pioneering the Hydrogen Economy. Foreign Service Journal 2003, Dec, 62-65.

3. Frankel, J. Iceland Harnesses Green Energy for Heat, Power, May 3, 2006. MSNBC Web site. www.msnbc.msn.com/id/12601052/ (accessed Dec 2006).

4. Nibkin, D. Iceland Hots Up Towards Hydrogen: A Nationwide Test Bed for Hydrogen and Fuel Cell Technologies Is Taking Shape in Northern Europe. The Fuel Cell Review 2006, June/July. Fuel Cell Today Web site. www.fuelcelltoday.com/FuelCellToday/FCTFiles/ FCTArticleFiles/Article_1114_FCRJunJulyNews5.pdf (accessed Nov 2006).

5. Lines, S., Natural Resources Canada. HyFATE, personal communication, Dec 5, 2006.

6. Industry Canada; Fuel Cells Canada; PricewaterhouseCoopers. Canadian Fuel Cell Commercialization Roadmap, March 2003. http://strategis.ic.gc.ca/epic/internet/inmseepe.nsf/vwapj/FuelCellsTRM_e.pdf/\$FILE/FuelCellsTRM_e.pdf (accessed Nov 2006).

7. Tak, J. A Year of Growth for the Canadian Hydrogen \& Fuel Cell Industry. Fuel Cell Catalyst 2005, 6 (1). www.usfcc.com/resources/Catalyst_Fall2005.pdf (accessed Nov 2006).

8. Natural Resources Canada. Canadian Transportation Fuel Cell Alliance, CANMET Energy Technology Centre. www.nrcan.gc.ca/es/etb/ctfca/index_e.html (accessed Dec 2006).

9. Elmegreen, L.; Henn, B.; Maletz, K.; Meng, K.; Orgill, I. Hydrogen Economy, Chemistry of the Environment, Chemistry Department, Princeton University, Fall 2004. www.princeton.edu/ chm333/2004/Hydrogen (accessed Nov 2006). 
10. European Commission. High Level Group on Hydrogen and Fuel Cells, Energy Research. http://ec.europa.eu/research/energy/nn/nn_rt/nn_rt_hlg/article_1146_en.htm (accessed Dec 2006).

11. Trezona, P. The European Hydrogen \& Fuel Cell Technology Platform Strategy. Fuel Cell Catalyst 2005, 6 (1). www.usfcc.com/resources/Catalyst_Fall2005.pdf (accessed Nov 2006).

12. EurActiv. Hydrogen and Fuel Cells, Nov 21, 2006. www.euractiv.com/en/transport/ hydrogen-fuel-cells/article-159887 (accessed Dec 2006).

13. International Partnership for the Hydrogen Economy. 2006 IPHE Annual Awards Program. www.iphe.net/IPHE\%20Awards\%202006.pdf (accessed Nov 2006).

14. QuestAir Technologies Inc. QuestAir H-3200 Hydrogen Purifier Installed in World's First Mobile Natural Gas-to-Hydrogen Fuel Station, News Release, Aug 12, 2004. www.questairinc.com/investor_relations/press_releases/archived_releases/2004/pdf/0812.pdf (accessed Nov 2006).

15. Ministry of Economy, Trade, and Industry. Opening of the JHFC Centrair Hydrogen Station (demonstration study of fuel cell systems), Press Release, July 18, 2006. www.meti.go.jp/english/information/downloadfiles/PressRelease/060718JHFCcentrair.pdf (accessed Nov 2006).

16. Akamatsu, H. Japan Hydrogen \& Fuel Cell Project in Final Year. Fuel Cell Catalyst 2005, 6 (1). www.usfcc.com/resources/Catalyst_Fall2005.pdf (accessed Nov 2006).

17. DaimlerChrysler Japan Co., Ltd. European Fuel Cell Bus Project Extended by One Year, March 2, 2006. www.daimlerchrysler.co.jp/news/2006/20060310_e.html\#1 (accessed Dec 2006)

18. Sigfusson, T. Iceland: the Hydrogen Island. Presented at the OECD Scientific Challenges for Energy Research, Paris, May 2006. www.oecd.org/dataoecd/13/11/36746599.pdf (accessed Nov 2006).

19. Schmidt, D.D.; Wocken, C.A.; Leroux, K.M.; Stevens, B.G.; Williams, K.D.; and Hill, R.R.; Wind-to-Hydrogen Feasibility Study; Final Report; Energy \& Environmental Research Center: Grand Forks, ND, Aug 2005.

20. Energy Information Administration. Estimated Petroleum Consumption: Transportation Sector, 1949-2005; Table 5.13c.

21. Energy Information Administration Energy Kid’s. Pagewww.eia.doe.gov/kids/energyfacts/ sources/SecondaryHydrogen.html (accessed Nov 2006).

22. Joyce, M. Developments in U.S. Alternative Fuel Markets; Energy Information Administration, (accessed Nov 2006). 
23. U.S. Department of Energy Office of Energy Efficiency and Renewable Energy Web site. www1.eere.energy.gov/hydrogenandfuelcells/news_cost_goal.html (accessed Nov 2006).

24. Energy Information Administration Web site. www.eia.gov/emeu/aer/txt/ptb0524.html (accessed Nov 2006).

25. Ivy, J. Summary of Electrolytic Hydrogen Production, Milestone Completion Report; NREL/MP-560-36734; National Renewable Energy Laboratory, Sept 2004.

26. U.S. Department of Energy Office of Energy Efficiency and Renewable Energy Web site. www.eere.energy.gov/hydrogenandfuelcells/fuelcells/pdfs/fc_comparison_chart.pdf (accessed Nov 2006).

27. Schmidt, D.D.; Gunderson, J.R. Opportunities for Hydrogen: An Analysis of the Application of Biomass Gasification to Farming Operations Using Microturbines and Fuel Cells; Energy \& Environmental Research Center: Grand Forks, ND.

28. Energy Information Administration. Retail Sales of Electricity to Ultimate Customers: Total by End-Use Sector, 1992 through August 2006; Table 5.1.

29. The Fertilizer Institute Web site. www.tfi.org/factsandstats/fertilizer.cfm (accessed Nov 2006).

30. International Fertilizer Industry Association Web site. www.fertilizer.org (accessed Nov 2006).

31. Jones, G. Energy: The High Cost of Farming, Texas Farm Bureau. www.txfb.org/ texasagriculture/2005/120205/120205energy.htm (accessed Nov 2006).

32. Funderburg, E. Why Are Nitrogen Prices So High?, Ag News \& Views, April 2001. www.noble.org/ag/soils/nitrogenprices/index.htm (accessed Nov 2006).

33. Sawyer, J.E. Natural Gas Prices Affect Nitrogen Fertilizer Costs; Iowa State University Department of Agronomy, Jan 29, 2001.

34. The Fertilizer Institute Web site. www.tfi.org/factsandstats/fertilizer.cfm (accessed Nov 2006).

35. U.S. Department of Agriculture Economic Research Service. www.ers.usda.gov/Data/ FertilizerUse/Tables/Table4.xls (accessed Nov 2006).

36. Taylor, R.D.; Koo, W.W. The Relationship Between Prices of Natural Gas and Nitrogen Fertilizer; North Dakota State University Center for Agricultural Policy and Trade Studies, April 2006. 
37. Pacific Northwest Laboratory. An Assessment of the Available Windy Land Area and Wind Energy Potential in the Contiguous United States; PNL-7789; Pacific Northwest Laboratory, Aug 1991.

38. Joseck, F. Well-to-Wheels Case Study: Distributed Hydrogen Production via Steam Methane Reforming; U.S. Department of Energy, 2005.

39. U.S. Department of Energy. Energy Demands on Water Resources, Report to Congress on the Interdependency of Energy and Water; U.S. Department of Energy, Dec 2006.

40. Energy Information Administration Web site. www.eia.gov/dnav/ng/ng_pri_sum_ aepgo_fwa_dmef_.htm (accessed Nov 2006).

41. U.S. Department of Agriculture Economic Research Service. www.ers.usda.gov/Data/ FertilizerUse/Tables/Table7.xls (accessed Nov 2006). 